\title{
ANGÉLICA YOCHIY
}

\section{EXPRESSÃO DOS GENES DE ATIVAÇÃO IMEDIATA C-FOSE EGR-1 EM ENCÉFALOS DE RATOS SUBMETIDOS AO MODELO DO DESAMPARO APRENDIDO}

Tese apresentada ao Instituto de Psicologia da Universidade de São Paulo como parte dos requisitos para obtenção do título de Doutor

Área de concentração:

Neurociências e Comportamento

Orientador:

Prof $^{\text {a }}$. Dra. Maria Helena Leite Hunziker

Colaborador:

Prof. Dr. Luiz Roberto Giorgetti de Britto

São Paulo

2010 


\section{AUTORIZO A REPRODUÇÃO E DIVULGAÇÃO TOTAL OU PARCIAL DESTE TRABALHO, POR QUALQUER MEIO CONVENCIONAL OU ELETRÔNICO, PARA FINS DE ESTUDO E PESQUISA, DESDE QUE CITADA A FONTE.}

Catalogação na publicação

Biblioteca Dante Moreira Leite

Instituto de Psicologia da Universidade de São Paulo

Yochiy, Angélica.

Expressão dos genes de ativação imediata $c$-fos e egr-1 em encéfalos de ratos submetidos ao modelo de desamparo aprendido / Angélica Yochiy; orientadora Maria Helena Leite Hunziker. -- São Paulo, 2010.

$150 \mathrm{f}$.

Tese (Doutorado - Programa de Pós-Graduação em Psicologia. Área de Concentração: Neurociências e Comportamento) - Instituto de Psicologia da Universidade de São Paulo.

1. Desamparo aprendido 2. Aprendizagem 3. Retenção 4. Depressão 5. Transtorno de estresse pós-traumático I. Título.

BF575.H4 
EXPRESSÃO DOS GENES DE ATIVAÇÃO IMEDIATA C-FOSE EGR-1 EM ENCÉFALOS DE RATOS SUBMETIDOS AO MODELO DO DESAMPARO APRENDIDO

\author{
ANGÉLICA YOCHIY
}

\title{
DEFESA DE TESE
}

\section{BANCA EXAMINADORA}

(Nome e Assinatura)

(Nome e Assinatura)

(Nome e Assinatura)

(Nome e Assinatura)

(Nome e Assinatura)

Tese defendida e aprovada em 


\section{DEDICATÓRIA}

Dedico esta obra à minha família, pelo apoio durante os anos de trabalho que resultaram nesta tese. 


\section{AGRADECIMENTOS}

À minha orientadora, a Prof ${ }^{a}$. Dra. Maria Helena Leite Hunziker, que procurou me ensinar o máximo, e com quem sempre pude contar em todas as horas dessa caminhada.

Ao Prof. Dr. Luiz Roberto Giorgetti de Britto, de quem a ajuda e apoio foram totalmente imprescindíveis para que este trabalho se concretizasse.

Aos colegas e amigos do Laboratório de Análise Biocomportamental (LABC), que em meio às reuniões do grupo, conversas e muito mais me proporcionaram muito conhecimento e ótimos momentos. Ao Marcos Yamada, o primeiro a me aceitar no grupo, por não pestanejar em nos auxiliar em diversos momentos difíceis no laboratório, e por nos alegrar com todos aqueles chocolates na Páscoa.

Aos colegas e amigos do Laboratório de Neurobiologia Celular, que tornaram os dias de trabalho muito especiais, inesquecíveis. Agradeço a Rosana Pagano que me introduziu as técnicas do laboratório e supervisionou até que eu seguisse por minha própria conta, a Adilson Alves e Daniel Martins por incontáveis socorros no dia a dia, a Caroline Alencar pela providencial ajuda com a análise estatística, a Marucia Chacur por me auxiliar diversas vezes e a Erika Kinjo pelos esclarecimentos sobre o hipocampo.

Agradeço a todos que, embora não tenham seus nomes citados, de alguma forma também contribuíram com este trabalho. A mencionar, os coordenadores e secretárias do Programa de Pós-graduação em Neurociências e Comportamento (NEC) pelo apoio durante o curso, os funcionários do Instituto de Psicologia e Instituto de Ciências Biomédicas pela presteza com que sempre me atenderam, em especial os funcionários da Secretaria de Pós-Graduação, do biotério e da biblioteca do Instituto de Psicologia. 
Esta tese contou com a inestimável colaboração do Laboratório de Neurobiologia Celular do Departamento de Fisiologia e Biofísica (ICB/USP) para a realização dos procedimentos experimentais, e também com o apoio financeiro da Coordenação de Aperfeiçoamento de Pessoal de Nível Superior (CAPES) na forma de bolsa de estudo para a pós-graduanda. 


\section{RESUMO}

YOCHIY, A. Expressão dos genes de ativação imediata c-fos e egr-1 em encéfalos de ratos submetidos ao modelo do desamparo aprendido. São Paulo, 2010. 150 p. Tese. Instituto de Psicologia. Universidade de São Paulo.

O desamparo aprendido (DA) corresponde à dificuldade de aprendizagem operante em função de exposição prévia a choques incontroláveis. Esse efeito vem sendo proposto como modelo animal de depressão e também defendido por alguns pesquisadores como modelo animal para o transtorno de estresse pós-traumático (TEPT). O objetivo do presente trabalho foi examinar a ativação dos genes $c$-fos e egr-l em áreas do encéfalo de ratos submetidos ao tratamento que induz o desamparo aprendido, priorizando estruturas consideradas funcionalmente importantes para os distúrbios de aprendizagem, como a amígdala (AMI), o hipocampo (HIP) e o córtex pré-frontal medial (CPFm). Considerado importante para o desenvolvimento do desamparo aprendido por alguns autores, o núcleo septal lateral (NSL) também foi analisado. No estudo, ratos machos Wistar adultos, sujeitos do grupo Incontrolável (INC), após período de adaptação ao ambiente laboratorial, receberam 60 choques inescapáveis de 1,0 mA, 10 segundos de duração, ministrados nas patas a intervalos médios de 1 minuto. Após 24 horas, estes animais e os controles ingênuos (ING), que não receberam choques no tratamento, foram submetidos à contingência de fuga. Critérios de aprendizagem previamente estabelecidos foram aplicados para selecionar os animais do grupo ING que aprenderam, e para separar os sujeitos do grupo INC nos subgrupos dos animais que não aprenderam (DES) e dos que aprenderam normalmente (NDE). Grupos controle sem adaptação e sem choque (BIO), ou com adaptação e sem choque (ADA), também foram manipulados. Após o teste de aprendizagem, os animais foram anestesiados, perfundidos, e seus encéfalos extraídos. Os cortes dos encéfalos foram tratados para imunoperoxidase para revelar as proteínas Fos e Egr-1. Os resultados evidenciaram características distintas de expressão dos genes $c$-fos e egr-1 nas diferentes estruturas. Foi observado um aumento na imunorreatividade para Fos nas áreas CA1 do HIP e CPFm para o grupo ING, e uma redução do marcador Fos no CPFm do grupo DES se comparado ao grupo NDE. Um aumento na imunorreatividade para Egr-1 foi evidenciado no giro denteado (GD) do HIP do grupo DES em relação a todos os grupos, à exceção do grupo ING. Na região central da AMI o aumento para Egr1 ocorreu no grupo DES em relação ao grupo ING, e na região basolateral, entre o grupo DES e os grupos BIO e ING. Os coeficientes de correlação de Pearson mostraram covariação entre os dados das duas regiões da AMI e entre os dados do GD para Egr-1 e NSL para Fos e Egr-1. Também foi evidenciada uma maior correlação entre os dados dos dois marcadores no grupo DES, seguido do NDE e do ING, nesta sequência. Os dados indicam que circuitos neurais relacionados à aprendizagem e memória estão envolvidos no desenvolvimento do desamparo aprendido. 


\begin{abstract}
YOCHIY, A. Expression of the immediate early genes, $c$-fos and egr-1, in the rat brain in the learned helplessness model. São Paulo, 2010. 150 p. Thesis. Instituto de Psicologia. Universidade de São Paulo.
\end{abstract}

The learned helplessness (LH) phenomenon corresponds to difficulties in operant learning as a result of previous exposure to uncontrollable shocks. This effect has been suggested as an animal model of depression and posttraumatic stress disorder (PTSD). The purpose of this work was to examine the activation of $c$-fos and egr-1 genes in brain areas of rats exposed to treatment which induces the LH behavior, especially in some structures recognized as functionally important to learning disorders, such as the amygdala (AMI), the hippocampus (HIP), and the medial prefrontal cortex (mPFC). Cited as important to LH development the lateral septal nucleus (LSN) was also examined. In the experiment, adult male Wistar rats from the uncontrollable group (INC), after a 3-day exposure to the experimental conditions, received 60 inescapable $1.0 \mathrm{~mA}$ footshocks lasting 10 seconds each, applied at an average interval of 1.0 minute. After 24 hours, these animals and the naive controls (ING), which did not receive footshocks during treatment, were tested in a shuttlebox. Previously established criteria were applied to select the ING animals that learned the escape response, and also to sort the INC animals into nonlearning (DES) and learning (NDE) subgroups according to their performance during the escape test. Subjects not exposed to adaptation or footshocks (BIO), and subjects adapted but not exposed to footshocks (ADA) were also manipulated. All animals received anesthesia and after transcardiac perfusion had their brains removed, sectioned and immunohistochemically treated to reveal Fos and Egr-1 proteins. The results showed distinct attributes for c-fos and egr-1 gene expression in the brain structures examined. Data analysis revealed significantly higher Fos immunoreactivity in the HIP CA1 and mPFC in the ING group than in the other groups. A decrease was detected in Fos-positive nuclei in the DES group mPFC compared with the NDE group. An increase in the Egr-1 positive nuclei was found in the HIP dentate gyrus (DG) in the DES group compared with all the groups, except the ING group. An increment in Egr-1 imunoreactivity was also detected in the central AMI in the DES group in relation to ING group, and in the basolateral AMI in the DES group against the BIO and ING groups. Pearson's correlation test indicated covariation between data from central and basolateral AMI regions. A high correlation coefficient was found between data from DG for Egr-1 and from NSL for both Fos and Egr-1. A high correlation was observed between the two markers for the DES group, followed by the NDE and ING groups, in that sequence. The results suggest that the neural circuits underlying memory and learning are implicated in the development of the LH effect. 


\section{SUMÁRIO}

AGRADECIMENTOS

RESUMO vii

ABSTRACT viii

SUMÁRIO ix

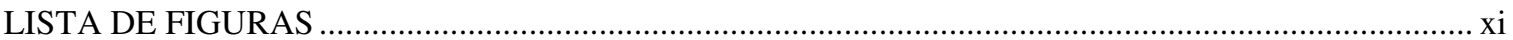

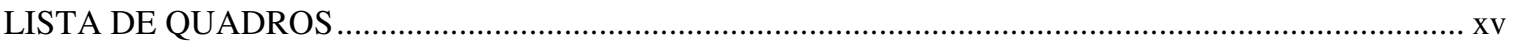

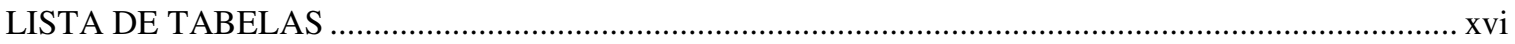

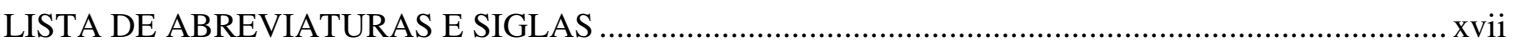

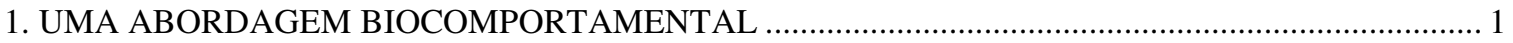

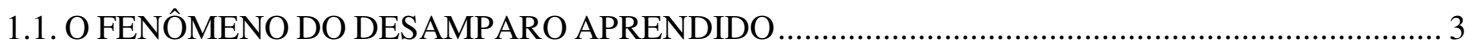

1.2. O MODELO ANIMAL DO DESAMPARO APRENDIDO …......................................................... 7

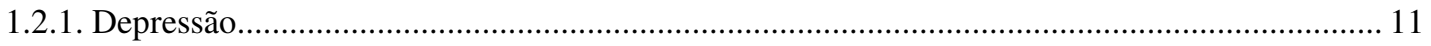

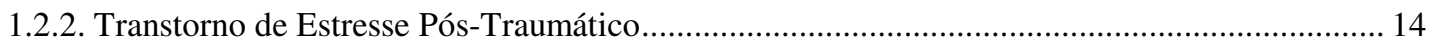

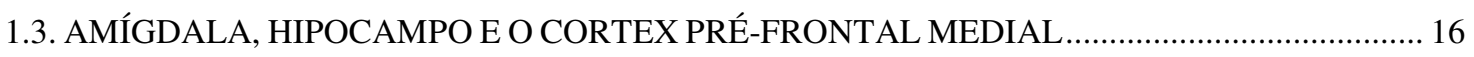

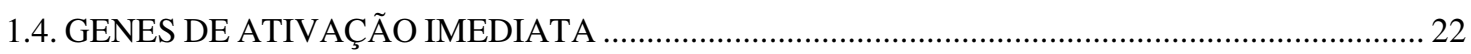

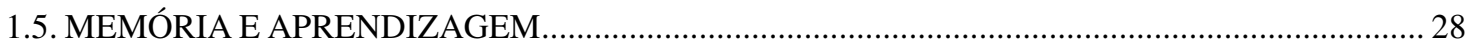

1.6. O DESAMPARO APRENDIDO E OS GENES C-FOS E EGR-1 …......................................... 31

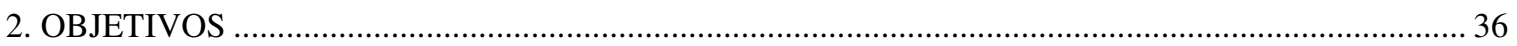

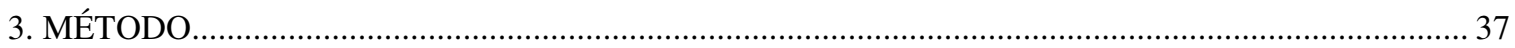

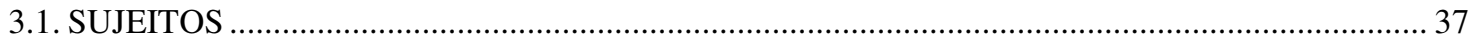

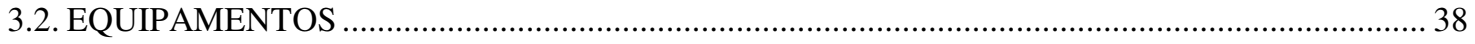

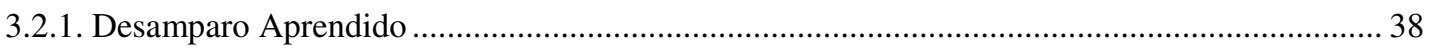

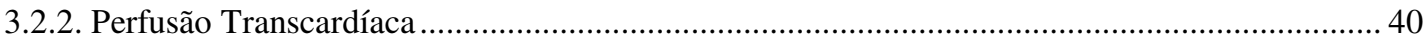

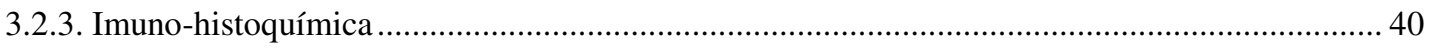

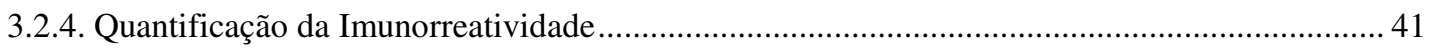

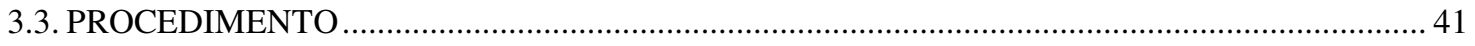

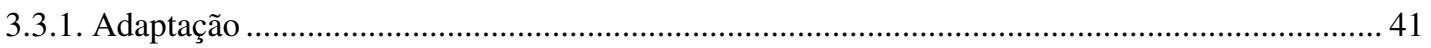

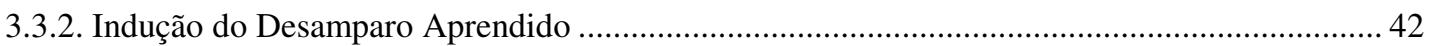

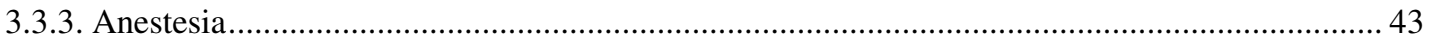




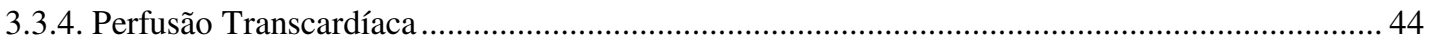

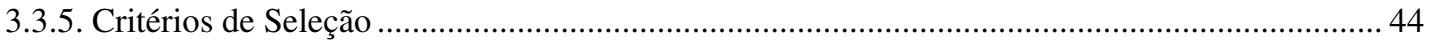

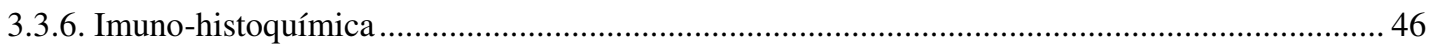

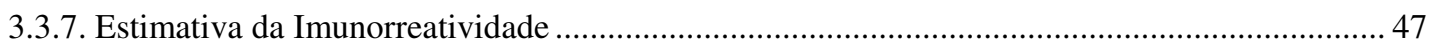

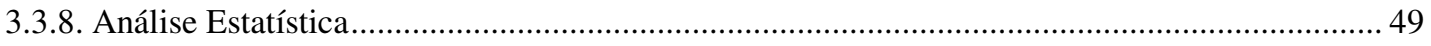

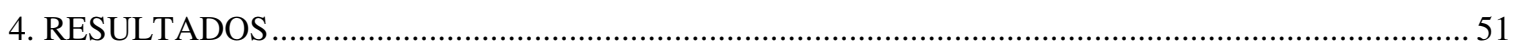

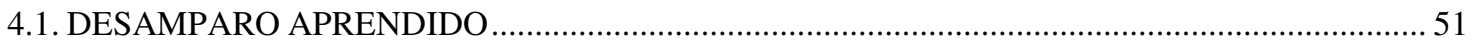

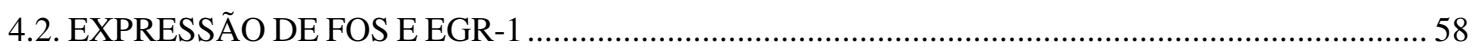

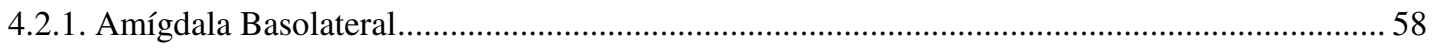

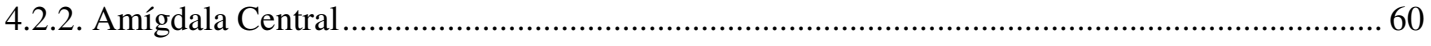

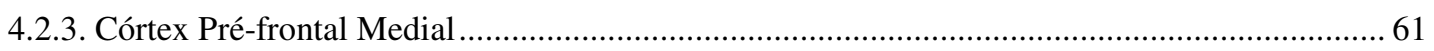

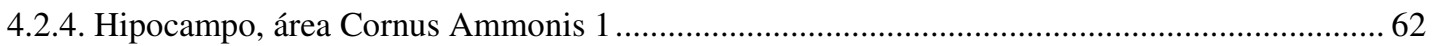

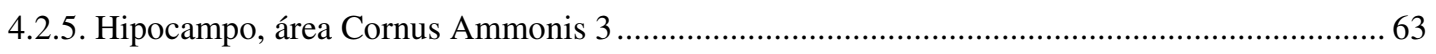

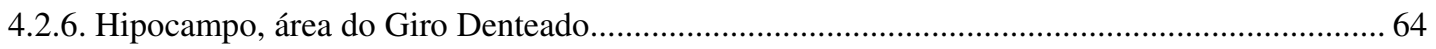

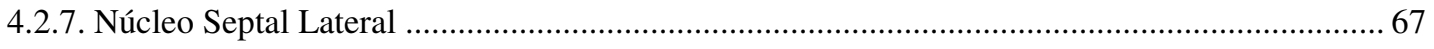

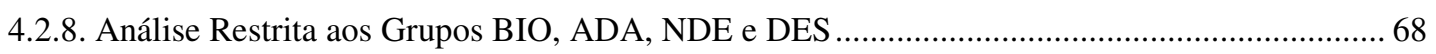

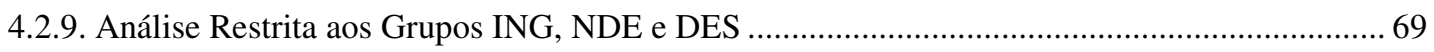

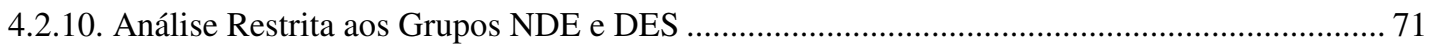

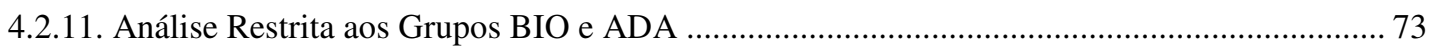

4.2.12. Análise Restrita ao Grupo BIO - Expressão Basal .................................................... 73

4.3. COVARIAÇÃO DOS DADOS DE IMUNORREATIVIDADE ................................................... 74

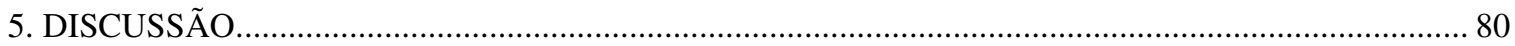

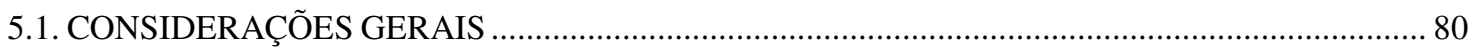

5.2. CARACTERÍSTICAS DA EXPRESSÃO DOS GENES............................................................ 83

5.3. A EXPRESSÃO DE FOS E EGR-1 E O DESAMPARO APRENDIDO ....................................... 86

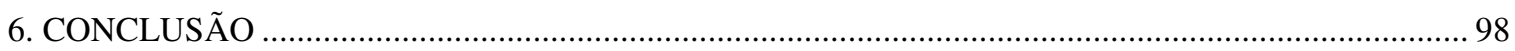

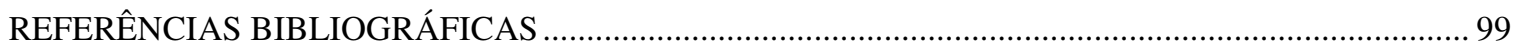

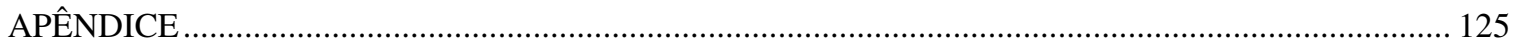

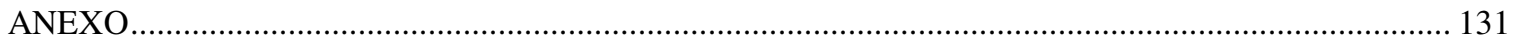




\section{LISTA DE FIGURAS}

Figura

Página

1 Caixa de teste de aprendizagem de fuga (shuttlebox) utilizada durante o experimento. A caixa distingue-se das usualmente citadas na literatura em função do orifício que permite a passagem entre os compartimentos ser elevado, exigindo a resposta de saltar, ao invés da resposta de correr registrada nas caixas onde a abertura fica ao nível do piso (ver Hunziker \& Santos, 2007).

2 Localização das áreas avaliadas nos ensaios imuno-histoquímicos (ilustrações modificadas de Paxinos \& Watson, 2005). A. Amígdala, central e basolateral; B. Córtex pré-frontal medial; C. Hipocampo, CA1, CA3 e giro denteado; D. Núcleo septal lateral.

3 Latências médias, em segundos (s), da resposta de fuga de saltar, agrupadas em blocos de 5 tentativas, apresentadas na sessão de teste pelos sujeitos do grupo ING.

4 Latências médias, em segundos (s), da resposta de fuga de saltar, agrupadas em blocos de 5 tentativas, apresentadas na sessão de teste pelos sujeitos do grupo DES, e as equações das retas de tendência ascendente ou estável.

5 Latências médias, em segundos (s), da resposta de fuga de saltar, agrupadas em blocos de 5 tentativas, apresentadas na sessão de teste pelos sujeitos do grupo NDE, e as equações das retas de tendência decrescente dos sujeitos que apresentaram latência média superior a $4,89 \mathrm{~s}$.

6 Latências médias, em segundos (s), das respostas de saltar apresentadas pelos animais dos grupos ING, NDE e DES, em blocos de 5 tentativas. Os grupos diferem entre si quanto ao número de sujeitos ( $\mathrm{n}$ indicado na figura).

7 Peso, em gramas (g), dos sujeitos dos grupos BIO, ADA, ING, NDE e

DES no dia do tratamento ou o correspondente, e as médias (-) de cada grupo. 
8 Valores médios ( \pm epm) de densidade de núcleos imunorreativos para Fos e Egr-1 na amígdala basolateral (ABL) dos grupos Biotério (BIO), Adaptação (ADA), Ingênuo (ING), Não Desamparado (NDE) e Desamparado (DES), e as médias totais dos marcadores para a estrutura. A análise estatística mostrou diferenças significantes na imunorreatividade para Egr-1 entre os grupos e entre as médias totais dos marcadores $(* \mathrm{p}<0,05)$.

9 Imagens digitais de secções de encéfalo que ilustram a densidade de marcação para Egr-1 encontrada na amígdala basolateral para os grupos Biotério, Ingênuo e Desamparado.

10 Valores médios ( \pm epm) de densidade de núcleos imunorreativos para Fos e Egr-1 na amígdala central (ACe) dos grupos Biotério (BIO), Adaptação (ADA), Ingênuo (ING), Não Desamparado (NDE) e Desamparado (DES), e as médias totais dos marcadores para a estrutura. A análise estatística mostrou diferença significante somente na imunorreatividade para Egr-1 entre os grupos ING e DES (*p < $0,05)$.

11 Valores médios ( \pm epm) de densidade de núcleos imunorreativos para Fos e Egr-1 no córtex pré-frontal medial (CPFm) dos grupos Biotério (BIO), Adaptação (ADA), Ingênuo (ING), Não Desamparado (NDE) e Desamparado (DES), e as médias totais dos marcadores para a estrutura. A análise estatística mostrou diferenças significantes para Fos entre os grupos e entre as médias totais dos marcadores $(* * * \mathrm{p}<$ $0,001)$.

12 Valores médios ( \pm epm) de densidade de núcleos imunorreativos para Fos e Egr-1 no hipocampo, área Cornus Ammonis 1 (CA1) dos grupos Biotério (BIO), Adaptação (ADA), Ingênuo (ING), Não Desamparado (NDE) e Desamparado (DES) e as médias totais dos marcadores para a estrutura. A análise estatística mostrou diferenças significantes na imunorreatividade para Fos entre os grupos e entre as médias totais dos marcadores $(* * \mathrm{p}<0,01, * * * \mathrm{p}<0,001)$.

13 Valores médios ( \pm epm) de densidade de núcleos imunorreativos para Fos e Egr-1 no hipocampo, área Cornus Ammonis 3 (CA3) dos grupos Biotério (BIO), Adaptação (ADA), Ingênuo (ING), Não Desamparado (NDE) e Desamparado (DES), e as médias totais dos marcadores nessa estrutura. A análise estatística evidenciou diferença significante somente entre as médias totais dos marcadores $(* p<0,05)$. 
14 Valores médios ( \pm epm) de densidade de núcleos imunorreativos para Fos e Egr-1 no hipocampo, área do giro denteado (GD) dos grupos Biotério (BIO), Adaptação (ADA), Ingênuo (ING), Não Desamparado (NDE) e Desamparado (DES), e as médias totais dos marcadores para essa estrutura. A análise estatística evidenciou diferenças significantes na imunorreatividade para Egr-1 entre os grupos e entre as médias totais dos marcadores $(* \mathrm{p}<0,05, * * \mathrm{p}<0,01, * * * \mathrm{p}<0,001)$.

15 Imagens digitais das secções de encéfalo que ilustram a densidade de marcação para Egr-1 observada no hipocampo, área do giro denteado, para os cinco grupos estudados no experimento.

16 Valores médios ( \pm epm) de densidade de núcleos imunorreativos para Fos e Egr-1 no núcleo septal lateral (NSL) dos grupos Biotério (BIO), Adaptação (ADA), Ingênuo (ING), Não Desamparado (NDE) e Desamparado (DES), e as médias totais dos marcadores para essa estrutura. A análise estatística mostrou diferença significante somente entre as médias totais dos marcadores $(* * * p<0,001)$.

17 Valores médios ( \pm epm) de densidade de núcleos imunorreativos para Fos ou Egr-1 na ABL, CPFm, CA1 e GD dos grupos Biotério (BIO), Adaptação (ADA), Não Desamparado (NDE) e Desamparado (DES). A análise estatística evidenciou diferenças significantes na imunorreatividade para Fos ou para Egr-1 entre os grupos $(* p<0,05$, $* * \mathrm{p}<0,01, * * * \mathrm{p}<0,001, \#$ novo dado significante).

18 Valores médios ( \pm epm) de densidade de núcleos imunorreativos para Fos ou Egr-1 na ABL, ACe, CPFm, CA1 e GD dos grupos Ingênuo (ING), Não Desamparado (NDE) e Desamparado (DES). A análise estatística evidenciou diferenças significantes na imunorreatividade para Fos ou para Egr-1 entre os grupos $(* \mathrm{p}<0,05, * * \mathrm{p}<0,01, * * * \mathrm{p}<$ 0,001).

19 Imagens digitais das secções de encéfalo que ilustram a densidade de marcação para Egr-1 observada na ACe para os grupos Ingênuo e Desamparado, cujas médias apresentaram diferença significante.

20 Valores médios ( \pm epm) de densidade de núcleos imunorreativos para Fos e Egr-1 nas estruturas CPFm e GD, respectivamente, para os grupos NDE e DES. A análise estatística evidenciou diferenças significantes na imunorreatividade para Fos no CPFm, e para Egr-1 no GD $(* \mathrm{p}<0,05, * * \mathrm{p}<0,01, \#$ novo dado significante).

21 Imagens digitais das secções de encéfalo que ilustram a diferença na densidade de marcação para Fos observada no CPFm entre os grupos NDE e DES, cujas médias apresentaram diferença significante. 
22 Valores médios $( \pm$ epm) de densidade de núcleos imunorreativos para Fos e Egr-1 nas estruturas estudadas para o grupo Biotério (BIO). A análise estatística evidenciou diferenças significantes na expressão basal dos marcadores Fos e Egr-1 nas estruturas $(* \mathrm{p}<0,05$, **p $<$ $0,01, * * * \mathrm{p}<0,001)$.

23 Diagramas de dispersão dos dados de imunorreatividade das 75 estruturas que resultaram em coeficientes de correlação de Pearson (r) significantes superiores a 0,6 .

24 Comparação dos valores médios $( \pm$ epm) de densidade de núcleos imunorreativos para Fos e Egr-1 nos cinco grupos experimentais. A análise estatística evidenciou diferenças significantes entre as médias para Fos e Egr-1 em todos os grupos $(* \mathrm{p}<0,05,(* * * \mathrm{p}<0,001)$

25 Diagramas de dispersão dos dados de imunorreatividade dos marcadores Fos e Egr-1 dos cinco grupos experimentais, com os respectivos valores de correlação de Pearson (r).

26 Comparação dos valores de densidade média total ( \pm epm) de núcleos imunorreativos para Fos e Egr-1, que apresentou diferença significante $(\mathrm{A}, * * * \mathrm{p}<0,001)$, e o diagrama de dispersão dos dados das duas proteínas com o respectivo coeficiente de correlação $(\mathrm{B}, \mathrm{r}=$ $0,7281, \mathrm{p}<0,0001)$.

27 Valores médios de densidade de núcleos imunorreativos por estrutura e marcador nos vários grupos. 


\section{LISTA DE QUADROS}

Quadro

Página

I Representação esquemática do experimento. Grupos com ou sem 48 adaptação, com ou sem tratamento com choques, com ou sem teste de aprendizagem de fuga. IET, intervalo entre tentativas médio; R, resposta; SN, se necessário; BIO, Biotério; ADA, Adaptação; ING, Ingênuo; INC, Incontrolável; NDE, Não desamparado; DES, Desamparado.

II Magnitude da correlação entre os valores de densidade de núcleos imunorreativos das estruturas, estimada por meio do coeficiente de correlação (r) de Pearson.

III Nível de significância dos coeficientes de correlação apresentados no Quadro II. 


\section{LISTA DE TABELAS}

Tabela

Página

1 Latências médias (s) das tentativas dos grupos Ingênuo (ING) e Desamparado (DES) e os resultados da análise de variância de duas vias para medidas repetidas (two-way ANOVA RM) com teste posthoc de Bonferroni.

2 Latências médias (s) das tentativas dos grupos Não Desamparado (NDE) e Desamparado (DES) e os resultados da análise de variância de duas vias para medidas repetidas (two-way ANOVA RM) com teste post-hoc de Bonferroni.

3 Latências médias (s) das tentativas dos grupos Ingênuo (ING) e Não Desamparado (NDE) e os resultados da análise de variância de duas vias para medidas repetidas (two-way ANOVA RM) com teste posthoc de Bonferroni. 


\section{LISTA DE ABREVIATURAS E SIGLAS}

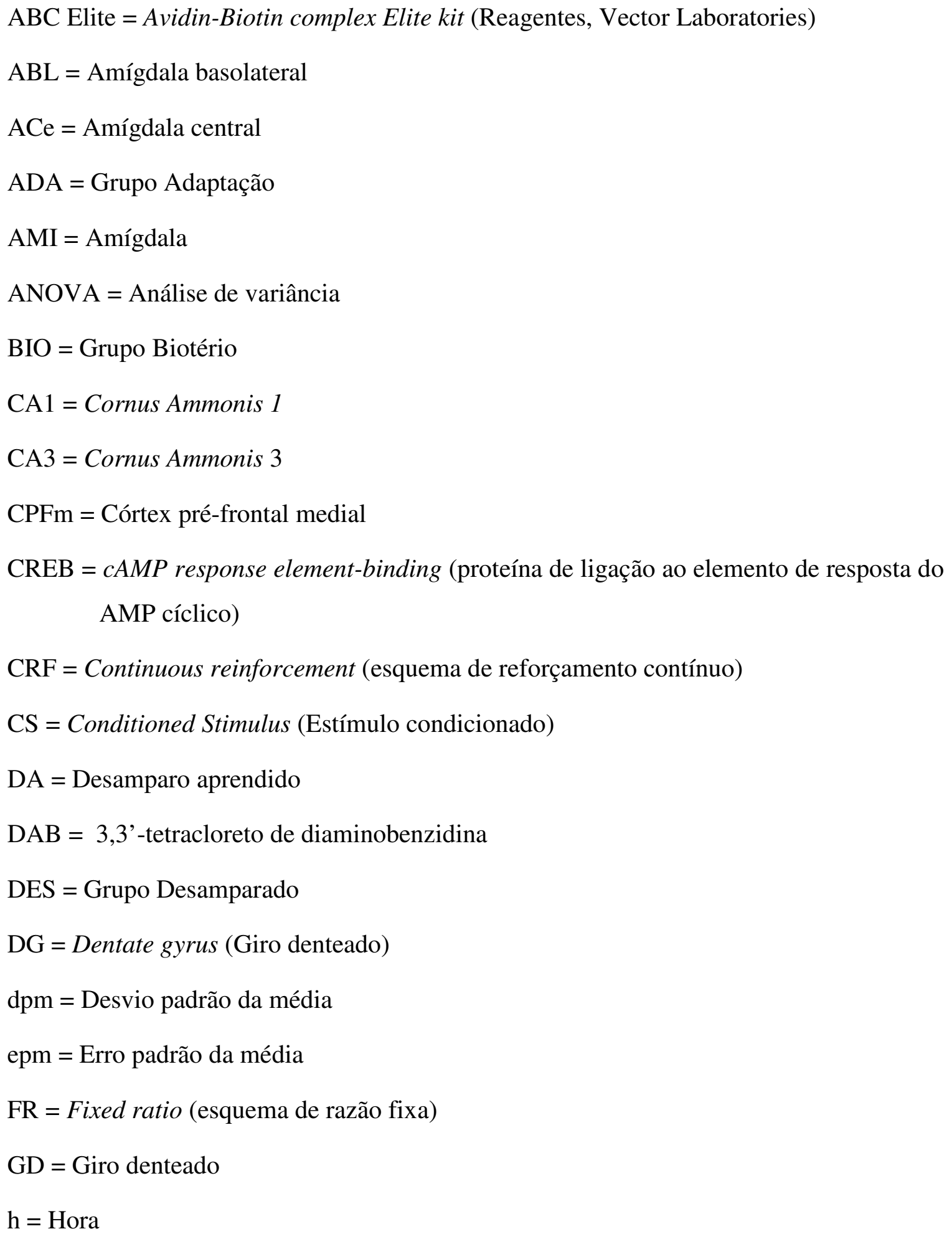


HIP = Hipocampo

INC $=$ Grupo Incontrolável

$\mathrm{ING}=$ Grupo Ingênuo

LABC = Laboratório de Análise Biocomportamental

LH = Learned helplessness (Desamparo aprendido)

LSN = Lateral septal nucleus (Núcleo septal lateral)

LTP $=$ Long-Term Potentiation (Potenciação de longo prazo)

$\mathrm{mA}=$ Miliampère

$\min =$ Minuto

mPFC = Medial prefrontal córtex (Córtex pré-frontal medial)

$\mathrm{n}=$ Número

NDE = Grupo Não Desamparado

NMDA $=N$-methyl-D-Aspartate (N-metil-D-aspartato)

NSL = Núcleo septal lateral

PTSD = Posttraumatic Stress Disorder (Transtorno de estresse pós-traumático)

$\mathrm{s}=$ Segundo

TEPT $=$ Transtorno de estresse pós-traumático

TR $=$ Trained Group (Grupo Treinado)

US = Unconditioned Stimulus (Estímulo incondicionado)

YK = Yoked Group (Grupo Acoplado) 


\section{UMA ABORDAGEM BIOCOMPORTAMENTAL}

"The behaving organism will eventually be described and explained by the anatomist and physiologist. As far as behavior is concerned, they will give us an account of the genetic endowment of the species and tell how that endowment changes during the lifetime of the individual and why, as a result, the individual then responds in a given way on a given occasion." B.F. Skinner, 1975, p. 42

O ambiente age sobre um organismo e é esse organismo, como um todo, que se comporta. As várias funções atribuídas às partes do organismo em sua interação com o ambiente fizeram surgir inúmeras disciplinas preocupadas em entender como o organismo funciona. O cérebro é uma das partes desse organismo que algumas dessas disciplinas estudam. Até o século 20 pouco se sabia sobre os processos fisiopatológicos que pudessem ajudar nas práticas terapêuticas, e o papel do ambiente, embora há muito percebido, só se tornou mais claro também naquele século (Skinner, 1975).

A interação entre o sistema nervoso de um organismo e o seu ambiente, como resultado da experiência, resulta na organização dos comportamentos simples e complexos do organismo e gera alterações tanto no ambiente como nos próprios circuitos neurais deste organismo (Ferrari, Toyoda, Faleiros, \& Cerutti, 2001). O comportamento complexo, a exemplo do "lembrar", é o resultado de uma multitude de eventos que ocorrem nos níveis comportamental, microcomportamental e fisiológico (Donahoe \& Palmer, 1994).

A abordagem que permite integrar os princípios básicos que explicam os fenômenos fisiológicos à análise das contingências ambientais que controlam o comportamento é denominada de biocomportamental (Donahoe \& Palmer, 1994). 
Diferentemente das abordagens que utilizam processos baseados somente nas inferências de observações comportamentais, a abordagem biocomportamental baseia-se em dados experimentais gerados por ciências independentes que podem complementar e beneficiar o estudo das relações funcionais entre o organismo e o ambiente (Donahoe \& Palmer, 1994).

Certamente o comportamento de "lembrar" já foi considerado um evento não observável em um período da história da ciência. Entretanto, com os avanços da tecnologia tais eventos podem tornar-se observáveis e serem biologicamente investigados, trazendo à luz informações importantes, antes inacessíveis, tal como afirmam Donahoe e Palmer (1994). Segundo Skinner (1990, p.1206), “o cérebro é parte do corpo e o que ele faz é parte do que o corpo faz. O que o cérebro faz é parte do que deve ser explicado".

Os avanços da Ciência até os dias de hoje trouxeram incontáveis progressos e, entre eles, novas tecnologias que permitem o estudo do funcionamento do cérebro enquanto o organismo se relaciona com o ambiente, como os estudos de neuroimagens. Como menciona Squire (2009, p. 12715), “a Ciência avança com a rapidez do desenvolver dos novos instrumentos e paradigmas que tornam possíveis novos questionamentos". Os novos dados gerados por essas tecnologias, com o tempo, devem contribuir de forma significativa para uma melhor compreensão das relações funcionais entre eventos mensurados ao nível comportamental (Donahoe \& Palmer, 1994), preenchendo as lacunas existentes nas explicações comportamentais, como previu Skinner (1987).

A pesquisa de como a comunicação ocorre no sistema nervoso, de como o funcionamento dos neurônios medeia a recepção dos estímulos ambientais e a execução 
das respostas comportamentais, pode contribuir para o entendimento de fenômenos como a aprendizagem (Donahoe \& Palmer, 1994).

Este trabalho procura desvendar algumas das alterações biológicas que ocorrem paralelamente ao efeito comportamental denominado desamparo aprendido. Esse efeito tem sido muito estudado em relação aos processos de aprendizagem envolvidos, mas conjuntamente a esses processos ocorrem incontáveis eventos biológicos, dos quais poucos foram investigados experimentalmente. Participar da empreitada de identificar alguns desses eventos foi o objetivo deste trabalho.

\subsection{O FENÔMENO DO DESAMPARO APRENDIDO}

Os primeiros trabalhos que levaram à detecção do efeito comportamental denominado desamparo aprendido (learned helplessness) ocorreram na década de 60, quando estudos sobre o comportamento de esquiva eram desenvolvidos no laboratório do Prof. Richard L. Solomon na Universidade da Pensilvânia, Estados Unidos. Nesse laboratório os estudos enfocavam a Teoria dos Dois Fatores ${ }^{1}$, que sugere que o comportamento de esquiva seria decorrente de dois processos de aprendizagem separados e potencialmente independentes, um respondente ${ }^{2}$ e outro operante ${ }^{2}$ (Overmier, 2002; Hunziker, 2005).

1 Para maiores detalhes, consultar Rescorla, R. R., \& Solomon, R. L. (1967). Two-process learning theory: relationships between Pavlovian conditioning and instrumental learning. Psychological Review, 74(3), 151-182.

2 Skinner deu origem aos termos respondente e operante em 1937, quando definiu respondente como o comportamento eliciado que ocorria em resposta à exposição a estímulos específicos do ambiente, e operante como o comportamento emitido que ocorria na ausência dessa estimulação (Morris \& Smith, 2004). Catania (1999) define respondente como a "classe de respostas definida em termos dos estímulos que as produzem fidedignamente", e operante como a "classe de respostas modificável pelas consequências das respostas da classe" (p. 420, 412). 
Ao manipular a ordem de aquisição dos condicionamentos respondente e operante em um dos experimentos sobre esquiva, os pós-graduandos Bruce Overmier e Russel Leaf observaram um resultado inesperado. No experimento, cães eram expostos à associação luz/choque incontrolável (associação CS/US) em uma primeira etapa e a teste de esquiva em uma segunda etapa. O teste ocorria dentro de uma caixa dividida em dois compartimentos na presença da luz. Um tom antecedia o choque por um intervalo fixo de tempo. Se o animal saltasse para o compartimento oposto, o som era desligado e o choque evitado. Ao contrário do que os pesquisadores esperavam, de que o pareamento luz-choque tornasse a luz um estímulo aversivo condicionado produzindo o reforçamento da resposta que a desligava, a luz não aumentou a probabilidade de saltar e a resposta de esquiva não foi aprendida (Overmier \& Leaf, 1965).

A pesquisa do efeito observado continuou em um novo estudo onde um grupo de cães recebia choques inescapáveis e outro grupo não recebia choques. Todos os animais, posteriormente, foram submetidos a um teste de fuga. Como resultado, obteve-se que, no teste, os animais que anteriormente tinham recebido choques inescapáveis não aprenderam a resposta de fuga, diferentemente do grupo não exposto a esse tratamento, que aprendeu normalmente (Overmier \& Seligman, 1967).

O isolamento das variáveis que produziam esse efeito de interferência na aprendizagem, no entanto, só foi obtido por Martin Seligman e Steven Maier com o delineamento de tríades. No procedimento triádico, foram estudados três grupos de cães dos quais dois recebiam choques no tratamento. A cada tentativa dois animais eram individualmente expostos ao choque, porém apenas um deles podia desligá-lo emitindo a resposta de focinhar em um painel. O focinhar desse sujeito desligava o choque para si e para o segundo animal a ele acoplado, enquanto um terceiro cão permanecia dentro de 
uma caixa experimental sem ser exposto a choques. Esse arranjo estabelecia, portanto, que o primeiro animal receberia choques controláveis, que o segundo receberia choques similares aos recebidos pelo primeiro animal, porém incontroláveis, e que o terceiro animal não receberia choques. Vinte e quatro horas após, quando submetidos ao teste de fuga, em uma contingência cuja resposta programada era saltar uma barreira, os resultados indicaram que apenas os animais expostos previamente aos choques incontroláveis apresentaram dificuldades na aprendizagem de fuga/esquiva; os animais que receberam choques iguais, porém controláveis, aprenderam a resposta com a mesma facilidade que os cães que nunca haviam sido expostos a choques. Portanto, esse estudo demonstrou que a variável crítica para o desenvolvimento do desamparo aprendido era a incontrolabilidade dos choques, e não os choques em si. Os pesquisadores denominaram essa dificuldade de aprendizagem de efeito de interferência. Esse termo, entretanto, rapidamente deu lugar a outro pelo qual o fenômeno é atualmente conhecido, o desamparo aprendido (Seligman \& Maier, 1967; Hunziker, 2003, 2005).

O desamparo aprendido é, portanto, um efeito comportamental que vem sendo caracterizado por dificuldade de aprendizagem por parte de indivíduos que tiveram histórico com eventos aversivos incontroláveis (Maier \& Seligman, 1976). Mais recentemente, Maier e Watkins (2005) relatam que o termo desamparo aprendido "refere-se a uma constelação de alterações comportamentais que ocorrem após exposição a estressores que não são controláveis por meio de respostas comportamentais, e que não ocorrem se o estressor é controlável” (p. 829).

A hipótese mais difundida para explicar esse efeito é de que o sujeito exposto a estímulos aversivos incontroláveis aprende que suas respostas a estes estímulos não os modificam, ou seja, que o seu comportamento não controla o ambiente. Como 
consequência, o mesmo sujeito passa a apresentar dificuldade para aprender respostas de fuga ou de esquiva quando estas lhe são possíveis (Maier \& Seligman, 1976; Hunziker, 2003; Maier \& Watkins, 2005). Mais recentemente, uma nova interpretação foi sugerida em função de haver estudos experimentais que produziram resultados não passíveis de serem explicados pela hipótese anterior. O que está sendo sugerido é que a incontrolabilidade dos choques torna os indivíduos mais sensíveis a vários aspectos da contingência, incluindo o controle por estímulos antecedentes e a contiguidade entre as respostas e suas consequências. Assim, variáveis do ambiente que podem ser irrelevantes, ou seja, que normalmente não controlariam os comportamentos dos sujeitos, passam a interferir no comportamento, competindo com o controle a ser exercido pelos aspectos críticos da contingência, dificultando a aprendizagem (Hunziker $\&$ Gehm, no prelo).

Ainda que algumas hipóteses formuladas nas décadas de 60 e 70 explicassem o fenômeno do desamparo aprendido como um mero déficit motor decorrente de reforçamento acidental da inatividade (Seligman \& Maier, 1967; Bracewell \& Black, 1974; Glazer \& Weiss, 1976 a, b), da depleção de catecolaminas (Weiss, Glazer, Pohorecky, Brick, \& Miller, 1975) ou de analgesia (Jackson, Maier, \& Coon, 1979; Moye, Hyson, Grau, \& Maier, 1983), a maior parte dos dados experimentais sugere que a exposição aos choques inescapáveis tem efeitos muito além do motor: em adição a reduzir a probabilidade do sujeito emitir a resposta de fuga/esquiva, o crítico desse efeito é que, mesmo que o animal emita a resposta e experimente o reforço negativo, seu comportamento não fica sob controle de suas consequências, ou seja, não tem sua probabilidade de ocorrência aumentada em função dessa relação de consequenciação experimentada (Maier \& Seligman, 1976). 


\subsection{O MODELO ANIMAL DO DESAMPARO APRENDIDO}

Segundo McKinney (1984), os modelos animais são preparações experimentais desenvolvidas em uma espécie com o propósito de estudar os fenômenos que ocorrem em outra espécie, usualmente por meio do desenvolvimento de síndromes que se assemelhem àquelas apresentadas pelos humanos. Os modelos animais geralmente são utilizados na pesquisa de sistemas biológicos e doenças quando o estudo em questão não pode ser conduzido em humanos (Kalueff \& Tuohimaa, 2004). Apesar das diferenças entre as espécies, várias áreas da ciência reconhecem que se beneficiam do conhecimento gerado pelos estudos realizados em modelos animais, existindo um amplo consenso de que os mesmos são fundamentais para o estudo da relação entre genes, cérebro e comportamento (Fisch \& Holmes, 2007).

Os psicofarmacologistas se interessam pelo fenômeno do desamparo aprendido principalmente em razão da sua vinculação à depressão humana (Seligman, 1975) e a sua utilização como modelo de depressão (Sherman, Allers, Petty, \& Henn, 1979; Sherman, Sacquitne, \& Petty, 1982; Willner, 1991a; Willner \& Mitchell, 2002) e estresse (Nestler, Gould, Manji, Buncan, Duman, Gershenfeld, Hen, Koester, Lederhendler, Meaney, Robbins, Winsky, \& Zalcman, 2002; Cryan, Markou, \& Lucki, 2002; Kalueff \& Tuohimaa, 2004), muito embora alguns pesquisadores tenham sugerido que o mesmo é mais apropriado como modelo do Transtorno de Estresse PósTraumático (Foa, Zinbarg, \& Rothbaum, 1992; Nestler et al., 2002; Willner \& Mitchell, 2002). Segundo Bremner, Southwick e Charney (1991), o modelo do desamparo 
aprendido imita a exposição ao estresse ${ }^{3}$ traumático dos indivíduos que desenvolvem o transtorno e produz nos animais uma variedade de comportamentos que se assemelham àqueles observados em pacientes com o distúrbio (van der Kolk, Greenberg, Boyd, \& Krystal, 1985; Foa et al., 1992), o que levaria o modelo a ser útil para o estudo das consequências comportamentais e neurobiológicas da exposição a eventos traumáticos (van der Kolk, 1987; Bremner et al., 1991; Koba, Kodama, Shimizu, Nomura, Sugawara, Kobayashi, \& Ogasawara, 2001). Segundo Foa et al. (1992) as reações de excitação aos estímulos condicionados, a analgesia e esquiva dos animais submetidos a eventos aversivos incontroláveis seriam análogas aos sintomas de re-experimentação, entorpecimento e evitação de atividades e situações que recordem o trauma observado nos pacientes.

No caso da depressão, ainda que os modelos animais não reproduzam completamente o distúrbio apresentado pelos humanos, no caso do desamparo aprendido vários aspectos são reproduzidos (Wong \& Licinio, 2001, 2004; Nestler et al., 2002; Willner \& Mitchell, 2002). Quanto à sintomatologia, foram encontradas similaridades entre alguns comportamentos dos animais e de pessoas deprimidas, por exemplo, passividade e pouca reatividade a estímulos supostamente reforçadores. No que diz respeito à etiologia, estímulos aversivos intensos, especialmente os incontroláveis, podem desencadear alguns tipos de depressão em humanos, e da mesma forma levar os

\footnotetext{
${ }^{3} \mathrm{O}$ termo estresse é pouco preciso, sendo amplamente utilizado para referir-se ao estímulo, à resposta ou à combinação de ambos, sendo o mesmo considerado por alguns autores como uma pseudo-explicação, com pouco valor real (Selye, 1975; Charlton, 1992; Kim \& Diamond, 2002; McEwen, 2005). Kim e Diamond (2002) propõem que estresse seja definido levando em conta três componentes: (1) excitabilidade mensurável operacionalmente, (2) aversividade à qual, dada a oportunidade, o sujeito reagiria para evitar ou atenuar os efeitos, e (3) a incontrolabilidade/imprevisibilidade. O termo estresse é utilizado aqui dado o seu emprego na literatura científica, sendo equivalente a estímulo aversivo. Em relação ao termo trauma, este deverá ser entendido como a exposição ao estímulo aversivo muito intenso.
} 
animais a apresentar o desamparo aprendido (Willner, 1984, 1985). Modificações bioquímicas (como níveis elevados de corticosterona e do fator liberador da corticotrofina), alterações na movimentação dos olhos durante o sono, diminuição do comportamento sexual, redução do peso corporal, que estão presentes em pacientes com depressão, também foram observadas em animais que apresentaram este efeito comportamental (Willner, 1991 a, b; Nestler et al., 2002). Por fim, similaridades entre a prevenção e tratamento clínico da depressão são apontadas nos estudos experimentais sobre imunização ${ }^{4}$ e reversão ${ }^{5}$ do desamparo aprendido em animais (Seligman, Rosellini, \& Kozak, 1975; Klein \& Seligman, 1976; Jones, Nation, \& Massad, 1977), além dos paralelos observados em estudos de fármacos antidepressivos (Sherman et al., 1982).

Willner (1984), ao avaliar diversos modelos de depressão, utilizou como critério a semelhança do modelo à condição modelada em sua etiologia, aspectos bioquímicos, sintomatologia e tratamento. A avaliação, levando em consideração a validade preditiva, a validade de face e a validade de constructo, indicou que o desamparo aprendido era um dos melhores modelos para o estudo da depressão em termos de validade global. A validade preditiva implica que as manipulações que influenciam o distúrbio no ser humano devem apresentar efeitos similares no modelo; a validade de face refere-se à similaridade existente entre os sintomas observados no modelo e em humanos; e a validade de constructo verifica a solidez da racional teórica (Willner \& Mitchell, 2002). Atualmente, apesar da existência de reconhecidas limitações, o modelo do desamparo

\footnotetext{
${ }^{4} \mathrm{O}$ termo imunização refere-se à condição na qual a exposição do animal a uma condição de controle antes da condição de incontrolabilidade impede que ele apresente, no teste, o efeito de desamparo aprendido (Hunziker, 2003, 2005).

${ }^{5} \mathrm{O}$ termo reversão refere-se à condição na qual o contato (muitas vezes forçado) do animal com novas contingências operantes pode reverter o efeito de desamparo aprendido anteriormente detectado (Hunziker, 2003, 2005).
} 
aprendido é considerado um dos melhores modelos animais de depressão (Hajszan, Dow, Warner-Schmidt, Szigeti-Buck, Sallam, Parducz, Leranth, \& Duman, 2009).

O principal obstáculo para a pesquisa da depressão em animais é que se trata de uma condição na qual, em humanos, há uma forte ênfase de aspectos subjetivos que não podem ser reproduzidos em animais. Mesmo assim, os modelos animais são considerados ferramentas indispensáveis na identificação de novos medicamentos antidepressivos e também na pesquisa dos processos envolvidos no desenvolvimento da depressão (Sherman et al., 1982; Cryan et al., 2002; Kalueff \& Tuohimaa, 2004).

O estudo de transtornos que resultam da exposição a eventos traumáticos utilizando o modelo do desamparo aprendido apresenta limitações, ainda que exista o reconhecimento da presença de similaridades neuroquímicas e comportamentais. Segundo Yehuda e Antelman (1993), o modelo não é baseado no conhecimento do agente etiológico primário que produz o transtorno. Esses pesquisadores afirmam que o modelo desenvolve uma mudança comportamental temporária e unidirecional, assim seu apelo estaria somente em sua aparente validade de face, o que seria insuficiente para estabelecê-lo como modelo para o transtorno traumático (Yehuda \& Antelman, 1993). A duração das modificações induzidas pelo processo, entretanto, que seriam duradouras e bidirecionais em humanos (Yehuda \& Antelman, 1993) e limitadas a 72 horas ou menos nos modelos em animais (Overmier \& Seligman, 1967; Maier, Coon, McDaniel, Jackson, \& Grau, 1979) é controversa. Há muitos indícios de que as alterações comportamentais que ocorrem no modelo do desamparo aprendido são duradouras.

Hunziker e Santos (2007) demonstraram o desamparo aprendido em ratos após 30 dias do tratamento com choques incontroláveis, e Mestre e Hunziker (1996) relataram o desamparo aprendido em ratos após um intervalo de 60 dias entre o tratamento e o 
teste de fuga. Além desses estudos, Maier (2001) registrou um aumento na duração do DA/depressão comportamental quando ratos machos que receberam choques inescapáveis foram expostos posteriormente ao ambiente no qual os choques ocorreram. Louvart, Maccari, Ducrocq, Thomas, e Darnaudéry (2005) também relataram a eliciação de distúrbios por mais de um mês após choque intenso nas patas de ratas quando os animais foram colocados por três vezes em ambiente próximo ao do choque inescapável, e Koba et al. (2001) relataram modificações comportamentais consideradas duradouras (2 semanas) em ratos machos.

Miller e McEwen (2006) reconhecem que o estudo de alguns aspectos do transtorno de estresse pós-traumático em animais é particularmente desafiador, uma vez que alguns dos sintomas que caracterizam esse distúrbio, como os pesadelos, "flashbacks" e ansiedade em relação a estímulos, seriam praticamente impossíveis de serem reproduzidos fora da espécie humana. Esses autores, entretanto, lembram que as principais estruturas encefálicas envolvidas na retenção da informação e no processo de resposta a tais estímulos são as mesmas nas várias espécies de mamíferos, de maneira que a pesquisa em modelos animais permanece essencial para que os aspectos anatômicos, funcionais e moleculares relativos à comunicação entre tais regiões possam ser compreendidos (Miller \& McEwen, 2006).

\subsubsection{Depressão}

A depressão é uma psicopatologia conhecida desde a antiguidade que, ainda hoje, é considerada um distúrbio de etiologia complexa e desconhecida (Wong \& Licinio, 2001, 2004), caracterizada por um conjunto de sinais e sintomas de descrição subjetiva e 
de difícil identificação (Kanter, Callaghan, Landes, Busch, \& Brown, 2004; Wong \& Licinio, 2001, 2004). Embora em evolução durante décadas, o primeiro sistema de classificação da depressão bem aceito na literatura médica foi publicado pela Associação Americana de Psiquiatria em 1980. Nessa publicação, o DSM III (Diagnostic and Statistical Manual of Mental Disorders III), surgiu o termo “Major Depressive Disorder" para identificar esse distúrbio (Gruenberg, Goldstein, \& Pincus, 2005).

Em termos comportamentais, Ferster (1973) analisou a depressão como uma redução na frequência de respostas em função da falta de reforçadores. Destaque-se que nessa análise, "a falta de reforçadores", que é o ponto central, pode ter diferentes origens, desde baixa disponibilidade de reforços até a baixa sensibilidade dos indivíduos aos estímulos disponíveis que poderiam ter a função de reforços. O modelo do desamparo aprendido é compatível com essa proposta, uma vez que o efeito em análise é caracterizado pela não emissão, ou emissão de respostas operantes com baixa frequência. A insensibilidade às contingências de reforçamento é observada quando os animais, apesar de experimentarem a contingência de fuga em vigor, não aprendem essa resposta (Hunziker, 2003). A falta de adequação do repertório do sujeito às mudanças nas contingências, leva ao não reforçamento das respostas emitidas e, em consequência, à redução de sua frequência e a um quadro ainda mais acentuado de falta de reforço, característico da depressão (Hunziker, 1997) ${ }^{6}$.

Apesar dos muitos anos de pesquisa, considera-se que muito pouco dos eventos fisiopatológicos envolvidos na depressão, ou dos mecanismos moleculares dos tratamentos medicamentosos, seja conhecido (Vollmayr \& Henn, 2001; Vaidya \&

\footnotetext{
${ }^{6}$ Informações mais detalhadas sobre a depressão, o desamparo aprendido e os aspectos comportamentais envolvidos, podem ser encontradas no artigo de Hunziker (2005). Esse e outros estudos sobre o desamparo aprendido estão disponíveis no site http://www.usp.br/labcl.
} 
Duman, 2001). Recentemente, no entanto, têm surgido evidências da ocorrência de alterações plásticas nos cérebros dos pacientes deprimidos, e de que os mecanismos celulares e moleculares da neuroplasticidade estariam implicados no efeito terapêutico de antidepressivos (Vaidya \& Duman, 2001; Duman, 2002a; D'Sa \& Duman, 2002; Fuchs, Czéh, Kole, Michaelis, \& Lucassen, 2004; Malberg, 2004; Warner-Schmidt \& Duman, 2006; Saray, \& Hen, 2007; Paizanis, Hamon, \& Lanfumey, 2007; Racagni \& Popoli, 2008).

As hipóteses atuais de indução e manutenção da depressão têm sugerido que a neuroplasticidade hipocampal está envolvida na fisiopatologia da depressão (Wong \& Licinio, 2004; Paizanis et al., 2007; Fornal, Stevens, Barson, Blakley, PattersonBuckendahl, \& Jacobs, 2007), e que uma redução na proliferação das células granulares do giro denteado induzida pelo estresse levaria ao desenvolvimento dos episódios depressivos (Chen, Pandey, Dwivedi, \& 2006; Duman, 2002a, 2002b). Entretanto, Vollmayr, Mahlstedt e Henn (2007), com base em dados obtidos em modelos animais, argumentam contra a hipótese de que uma redução na neurogênese seja a causa ou a consequência do comportamento depressivo, uma vez que esse comportamento pode ocorrer sem prejuízos na neurogênese e que a redução na neurogênese não necessariamente leva ao comportamento similar ao depressivo nos animais. Portanto, não há uma compreensão precisa da relação entre a depressão e uma possível disfunção relacionada à neuroplasticidade, embora os estudos também mostrem prejuízos no aprendizado e memória dos pacientes (Pittenger \& Duman, 2008).

Estudos de neuroimagens em pacientes deprimidos têm detectado interações disfuncionais entre a amígdala (AMI) e o córtex pré-frontal medial (Drevets, 1999; Drevets, Price, \& Furey, 2008). Esses dados, em conjunto com a análise de lesões e de 
informações obtidas através de técnicas post-mortem, levaram Drevets et al. (2008) a propor um modelo de circuito neural que se baseia na suposição de que o córtex préfrontal medial e os circuitos que o conectam com outras estruturas límbicas e corticais estariam disfuncionais na depressão.

A frequência com que pacientes traumatizados apresentam quadros depressivos levou O’Donnell, Creamer e Pattison (2004) a investigarem se o transtorno de estresse pós-traumático e a depressão seriam patologias separadas ou parte de um único processo traumático nesses pacientes, chegando à conclusão que a depressão pode ser identificada até alguns meses após o trauma, mas que com o passar do tempo a distinção se torna muito difícil.

\subsubsection{Transtorno de Estresse Pós-Traumático}

O transtorno de estresse pós-traumático é um distúrbio potencialmente incapacitante que pode ocorrer em pessoas expostas a evento traumático ou situação extrema envolvendo perigo de morte. Por exemplo, esse transtorno pode ser identificado em sobreviventes de acidentes de veículos automotores, veteranos de guerra, vítimas de estupros, assaltos, sequestros e outras situações de violência (Ramaswamy, Madaan, Qadri, Heaney, North, Padala, Sattar, \& Petty, 2005).

As primeiras teorias sobre esse transtorno foram desenvolvidas durante e após a Segunda Grande Guerra, porém a Associação Americana de Psiquiatria somente publicou os primeiros critérios para diagnóstico do transtorno em 1980, introduzindo o uso do termo "Posttraumatic Stress Disorder" como oficial para identificar a condição (Ramaswamy et al., 2005). O transtorno em questão se desenvolve em indivíduos 
quando estes se confrontam com situações aversivas que vão além da sua capacidade de adaptação, e seria caracterizado por três conjuntos duradouros de sinais e sintomas: a reexperimentação (flashbacks, lembranças indesejáveis e pesadelos repetitivos), a esquiva em relação aos estímulos associados ao evento aversivo traumático, e excitamento excessivo (Yehuda \& LeDoux, 2007). Os pacientes diagnosticados com esse transtorno também apresentam lembranças autobiográficas e traumáticas fragmentadas, amnésia parcial relacionada ao evento traumático e dificuldade para lembrar eventos, fatos e listas (Elzinga \& Bremner, 2002).

Muitos dos sintomas do transtorno de estresse pós-traumático são entendidos como respostas condicionadas do indivíduo a estímulos associados ao evento traumático (Wessa \& Flor, 2007). A persistência das respostas do indivíduo a esses estímulos aversivos é um aspecto característico observado nesse transtorno, em fobias e na síndrome do pânico (Izquierdo \& Cammarota, 2004). Situações do dia-a-dia que contenham tais estímulos podem disparar mecanismos que resultam em reações indesejáveis nos indivíduos traumatizados (Elzinga \& Bremner, 2002; Wessa \& Flor, 2007).

Ainda que o evento traumático seja necessário para o desenvolvimento do transtorno de estresse pós-traumático (Yehuda \& LeDoux, 2007), a maioria das pessoas expostas a esse tipo de experiência não o desenvolve (Breslau, Davis, Andreski, \& Peterson, 1991; Yehuda \& LeDoux, 2007). Os motivos pelos quais alguns indivíduos são resistentes e outros sensíveis ao trauma ainda são pouco conhecidos, questão essa que tem sido foco de muitas pesquisas (Haglund, Nestadt, Cooper, Southwick, \& Charney, 2007). Os modelos animais que envolvem reação ao estresse, como o modelo 
do desamparo aprendido, podem trazer um pouco de entendimento aos importantes aspectos psicofisiológicos da susceptibilidade ao trauma (Ramaswamy et al., 2005).

$\mathrm{Na}$ última década, estudos sobre os distúrbios que resultam da exposição a eventos traumáticos realizados em humanos, principalmente de neuroimagem, têm destacado a importância de três áreas do encéfalo, que são a amígdala, o córtex préfrontal medial e o hipocampo (Elzinga \& Bremner, 2002; Sheline, 2003; Miller \& McEwen, 2006; Shin, Rauch, \& Pitman, 2006; Liberzon \& Sripada, 2007; Yehuda \& LeDoux, 2007; Bremner, Elzinga, Schmahl, \& Vermetten, 2008; Drevets et al., 2008). Os dados evidenciam a ocorrência de aumento da ativação da amígdala, redução da ativação do córtex pré-frontal medial e prejuízos funcionais no hipocampo dos pacientes com estresse pós-traumático (Shin et al., 2006; Liberzon \& Martis, 2006; Yehuda \& LeDoux, 2007). Como ocorre com a depressão, há evidências de que o tamanho do hipocampo é menor em pacientes com esse distúrbio (Malberg, 2004; Sala, Perez, Soloff, Ucelli di Nemi, Caverzasi, Soares, \& Brambilla, 2004; Wang, Neylan, Mueller, Lenoci, Truran, Marmar, Weiner, \& Schuff, 2010).

\subsection{AMÍGDALA, HIPOCAMPO E O CORTEX PRÉ-FRONTAL MEDIAL}

A amígdala é composta de vários grupos distintos de células agrupadas em núcleos (Cardinal, Parkinson, Hall, \& Everitt, 2002). Os núcleos originalmente denominados lateral, basal e acessório formam a amígdala basolateral (ABL) (Davis \& Whalen, 2001). O complexo basolateral seria formado pela amígdala lateral, basolateral e basomedial (Knapska \& Kaczmared, 2004). As estruturas que ficam ao seu redor, inclusive os núcleos central, medial e cortical formam o complexo amigdalóide. Este 
complexo, juntamente com a amígdala basolateral, formam a amígdala (Davis \& Whalen, 2001). Em humanos, essa estrutura está presente na região temporal e é associada ao comportamento ansioso e à memória de eventos aversivos (Davis \& Whalen, 2001).

A amígdala tem sido reconhecida há muito tempo como uma estrutura do encéfalo importante na aquisição e na expressão do medo ${ }^{7}$, sendo que evidências mais recentes também a implicam na extinção (Barad, Gean, \& Lutz, 2006; Akirav \& Maroun, 2007; Muigg, Hetzenauer, Hauer, Hauschild, Gaburro, Frank, Landgraf, \& Singewald, 2008), ou seja, na supressão das respostas que permitem a sua observação. A extinção, outra forma de aprendizado na qual o responder condicionado ao estímulo é reduzido pela descontinuidade do pareamento, dependeria de estruturas específicas do cérebro, que seriam a amígdala basolateral, o córtex pré-frontal e o hipocampo (Delamater, 2004). Segundo Akirav e Maroun (2007) existem evidências indicando que a ocorrência da extinção seria dependente de alterações plásticas no córtex pré-frontal e na amígdala basolateral.

Cardinal et al. (2002) sugerem que a amígdala basolateral seria necessária para que o estímulo neutro se torne condicionado, isto é, adquira valor do estímulo incondicionado ao qual foi pareado, e como substrato de convergência sensorial das áreas corticais e subcorticais (Knapska \& Kaczmared, 2004). Em paralelo, a amígdala central (ACe) teria uma função de organização das respostas do medo condicionado aos estímulos fisicamente aversivos (Canteras, 2003). Assim, o sistema neural da resposta

\footnotetext{
${ }^{7}$ Termo subjetivo utilizado na literatura científica, aqui entendido como evento privado (estado interno) eliciado por estímulo aversivo que denota perigo ou ameaça iminente, e que pode resultar na emissão de comportamento de defesa (Pinto, 2001), por exemplo, a resposta de fuga ou congelamento, e assim se tornar acessível à observação experimental. $\mathrm{O}$ medo é aqui considerado, portanto, um produto da contingência ambiental proveniente de uma reação de defesa ao estímulo aversivo (Darwich \& Tourinho, 2005).
} 
condicionada a eventos aversivos, como a resposta de congelamento, seria mediado pela substância cinzenta periaquedutal e controlado pela amígdala central (Cardinal et al., 2002). O núcleo central da amígdala, no entanto, não parece estar envolvido na organização das respostas comportamentais quando, na contingência, um animal é exposto ao seu predador natural (Canteras, 2003; Rosen, 2004; Takahashi, Nakashima, Hong, \& Watanabe, 2005).

A amígdala também parece ser necessária para que a experiência seja retida. $\mathrm{Na}$ literatura, o efeito chamado de facilitação da memória ${ }^{8}$, é caracterizado quando eventos emocionalmente fortes são lembrados mais facilmente do que os eventos neutros. Esse efeito dependeria da ação de hormônios do estresse, como o cortisol, e da adrenalina na amígdala basolateral (Paré, 2003), estrutura que apresenta conexões com a amígdala central, o hipocampo e o córtex pré-frontal (Davis \& Whalen, 2001).

A formação hipocampal é uma estrutura localizada abaixo do córtex do lobo temporal em humanos, que é constituída pelo hipocampo (propriamente dito), o giro denteado e o complexo subicular. O hipocampo propriamente dito, que apresenta o formato de um C, é dividido nas subáreas Cornus Ammonis 1, 2 e 3 (CA1, CA2 e CA3). Essas subáreas são conectadas entre si, com o giro denteado e com o córtex entorrinal, por meio de um circuito denominado de tri-sináptico, formado pelas fibras da via perforante, pelas fibras musgosas e da via colateral de Schaffer (Spencer \& Bland, 2007). A formação hipocampal é caracterizada por uma organização em camadas onde são identificados dois tipos principais de células, as células piramidais (hipocampo e

\footnotetext{
${ }^{8} \mathrm{Na}$ Análise do Comportamento, o termo memória tem cunho meramente descritivo, referindo-se ao controle do comportamento atual por contingências passadas (Jans \& Catania, 1980)). Nesse sentido, toda e qualquer aprendizagem envolve memória. No presente texto, eventualmente, são transcritas algumas considerações na perspectiva da neurofisiologia onde o conceito de memória apresenta outro tipo de conotação, analisada em paralelo à aprendizagem.
} 
complexo subicular), e as células granulares (giro denteado), este último em forma de um V em razão da união das lâminas de células supra e infrapiramidais (Spencer \& Bland, 2007). A formação hipocampal é comumente denominada de "hipocampo", como em Lathe (2001), pressupondo a inclusão do giro denteado em razão de sua posição muito próxima, o que será adotado nesse trabalho.

O hipocampo (ou formação hipocampal) é uma estrutura que tem se mostrado altamente sensível ao estresse, sendo considerada importante para a regulação da resposta a estímulos estressores (Kim \& Diamond, 2002; Sala et al., 2004) e para a plasticidade sináptica (Kim \& Diamond, 2002; Neves, Cooke, \& Bliss, 2008). Essa estrutura é muito estudada em razão das evidências de sua importância para os processos relativos à memória (Elzinga \& Bremner, 2002). Como mencionado anteriormente, as alterações no hipocampo têm sido relacionadas ao desenvolvimento do transtorno de estresse pós-traumático e da depressão (Bremner, Narayan, Staib, Southwick, McGlashan, \& Charney, 1999; Sala et al., 2004)

A pesquisa, até hoje, tem enfocado de forma predominante os prejuízos que os estímulos estressores podem causar à memória, embora se saiba que a exposição esses estímulos pode ter efeito contrário. Todos sabem que os eventos emocionalmente carregados são lembrados mais facilmente do que os eventos neutros e, por esta razão, acredita-se que a amígdala exerça um complexo efeito modulador sobre o hipocampo, de melhora ou supressão, a depender do modo como a mesma é ativada (Abe, 2001).

Estudos com lesões têm mostrado que a amígdala basolateral está envolvida na plasticidade hipocampal e que a estimulação dessa estrutura facilitaria a ocorrência da potenciação de longo prazo (do inglês, $L T P$ ) no giro denteado (Ikegaya, Saito, \& Abe, 1995; Abe, 2001). A potenciação de longo prazo é um efeito de melhora duradoura da 
eficácia sináptica provocada por estimulações elétricas tetânicas de curta duração que é aceito por muitos pesquisadores como modelo de aprendizagem e memória (Herrera \& Robertson, 1996; Lynch, 2004), ainda que também existam evidências de que esse efeito seja inadequado para essa finalidade (Shors \& Matzel, 1997).

Segundo Bliss, Collingridge e Morris (2003), uma questão importante que precisa ser respondida é se os mecanismos neurais envolvidos na potenciação de longo prazo seriam os mesmos da memória e aprendizado, ou se estariam sobrepostos a estes. Em outras palavras, questiona-se se o mecanismo da potenciação de longo prazo seria apenas um modelo neural ou seria o mecanismo realmente utilizado pelo cérebro para guardar as informações. Bliss et al. (2003) lembram que, como os processos envolvidos na plasticidade sináptica e expressão de proteínas são dinâmicos, a longevidade da potenciação de longo prazo ainda seria uma questão a ser respondida. Esses mecanismos precisariam sustentar o aumento da força sináptica por longos períodos para que possam ser aceitos como um modelo de memória válido (Bliss et al., 2003).

Atualmente a potenciação de longo prazo é dividida em três tipos de acordo com a duração. A LTP1 ou early LTP com duração de duas horas, a LTP2 com duração de quatro dias, e a LTP3 com duração de vinte e três dias, as duas últimas também denominadas de late-LTP (Abraham, 2003; Knapska \& Kaczmarek, 2004). Em 2002, no entanto, Abraham e colaboradores anunciaram a obtenção de uma potenciação de longo prazo estável no giro denteado do hipocampo que se prolongou por meses (Abraham, Logan, Greenwood, \& Dragunow, 2002; Abraham, 2003). Estudos como esse seriam importantes porque eles demonstram que o mecanismo da potenciação de longo prazo pode teoricamente sustentar uma expansão temporal da memória (Abraham, 2003), isto 
é, sustentar o aumento da força sináptica por longos períodos de tempo anteriormente mencionado por Bliss et al. (2003).

O córtex pré-frontal consiste de regiões altamente interconectadas, que incluem o cingulado anterior e os córtices pré-límbico e infralímbico, com características ideais para integrar informações. O córtex pré-frontal apresenta conexões recíprocas com os córtices sensório, motor e límbico, conexões que permitiriam o seu funcionamento independente do hipocampo (Frankland \& Bontempi, 2005). Localizado no lobo frontal, o córtex pré-frontal tem sido frequentemente relacionado aos processos de aprendizado e memória (Nestler et al., 2002; Jung, Baeg, Kim, Kim, \& Kim, 2008), isto é, à aquisição de novos repertórios comportamentais e o comportamento de lembrar, que seriam de grande relevância no aparecimento da ansiedade, da depressão e do transtorno de estresse pós-traumático (Bremner et al., 1999; Bremner, Innis, Southwick, Staib, Zoghbi, \& Charney, 2000; Nestler et al., 2002).

O córtex pré-frontal medial, que é localizado medialmente ao fórceps minor, seria uma região importante porque teria uma atuação reguladora e de interface entre as estruturas límbicas e corticais, modulando os sistemas envolvidos (Akirav \& Maroun, 2007) e mediando as respostas em situações de estresse (Maroun \& Richter-Levin, 2003). Há evidências que sugerem que o córtex pré-frontal medial possui um papel crítico para a retenção e extinção de memórias (Milad, Rauch, Pitman, \& Quirk, 2006; Akirav \& Maroun, 2007), as quais dependeriam de circuitos que podem estar morfológica e funcionalmente comprometidos nos indivíduos que sofrem do transtorno de estresse pós-traumático (Quirk, Garcia, \& González-Lima, 2006). Em outras palavras, o córtex pré-frontal medial seria importante para manutenção e a supressão das respostas condicionadas ao estímulo aversivo, que por sua vez dependeriam de circuitos neurais 
que podem estar morfologicamente alterados ou disfuncionais nos indivíduos traumatizados. A extinção da memória aversiva, ou seja, a supressão da resposta condicionada eliciada pelo estímulo aversivo, exigiria como pré-requisito um novo aprendizado envolvendo o córtex pré-frontal medial e suas projeções para a amígdala (Likhtik, Pelletier, Paz, \& Paré, 2005), e esse aprendizado dependeria da ocorrência de alterações plásticas em ambas as estruturas (Akirav \& Maroun, 2007).

Em termos neuroanatômicos, a existência de convergência e interação das projeções amigdalares e hipocampais no córtex pré-frontal foi evidenciada também em ratos (Ishikawa \& Nakamura, 2003, 2006), e alterações sinápticas no hipocampo de animais submetidos ao modelo do desamparo aprendido têm sido detectadas (Hajszan et al., 2009).

\subsection{GENES DE ATIVAÇÃO IMEDIATA}

Os genes de ativação imediata são uma classe de genes cuja indução ocorre de forma imediata e transiente após a estimulação extracelular (Sheng \& Greenberg, 1990), dando origem a proteínas que apresentam diversas funções celulares (Chaudhuri, Zangenehpour, Rahbar-Dehgan, \& Ye, 2000). A ativação desse tipo de gene foi inicialmente caracterizada em células não neuronais (Sheng \& Greenberg, 1990).

O significado funcional da expressão dos genes de ativação imediata no cérebro ainda é pouco conhecido (Thiriet, Zwiller, \& Ali, 2001), suas proteínas possivelmente regulam a transcrição de outros genes que, por sua vez, devem participar de mecanismos

que irão gerar mudanças celulares de longo prazo (Herdegen \& Leah, 1998; Lanahan \& 
Worley, 1998; Malkani \& Rosen, 2000; Davis, Bozon, \& Laroche, 2003). Em outras palavras, a sua indução, que ocorre em um grande número de situações, pode constituir uma ligação entre os estímulos externos e as alterações de longo prazo nos fenótipos celulares (Herrera \& Robertson, 1996; Thiriet et al., 2001). A expressão neural dos genes de ativação imediata, induzida pelo estresse e exploração de ambientes novos, produziria os fatores de transcrição (Gallitano-Mendel, Izumi, Tokuda, Zorumski, Howell, Muglia, Wozniak, \& Milbrandt, 2007), que seriam proteínas úteis para a reorganização plástica das conexões das sinapses (Lanahan \& Worley, 1998; Kaczmarek, 2000). A elucidação dos padrões individuais de expressão desses fatores de transcrição no sistema nervoso pode contribuir para a compreensão da capacidade dos neurônios de reagir aos estímulos ambientais com modificações na expressão dos genes (Herdegen, Kovary, Buhl, Bravo, Zimmermann, \& Gass, 1995), sendo as proteínas das famílias Fos (Finkel e Osteogenic Sarcoma) e Egr (Early Growth Response) exemplos desses fatores de transcrição (Herdegen et al., 1995).

Os genes de ativação imediata $c$-fos e egr-1, respectivamente das famílias Fos e Egr, estão amplamente distribuídos por todo o encéfalo e têm sido utilizados como marcadores funcionais da atividade dos neurônios (Dragunow \& Faull, 1989; Chaudhuri, 1997; Krukoff, 1998; Zangenehpour \& Chaudhuri, 2002; Davis et al., 2003), sendo ferramentas importantes para o estudo da atividade neuronal apesar da existência de certas limitações (Chaudhuri, 1997; Kovács, 2008). Numerosos trabalhos têm demonstrado a indução dos genes fos e egr-1 em determinadas áreas do encéfalo mesmo na ausência de qualquer estimulação intencional. A expressão desses genes em ratos não submetidos a tratamento sugere que seus fatores de transcrição têm papel funcional no encéfalo de animais não tratados (Herdegen et al., 1995). Atualmente sabe-se que a 
expressão desses genes está fortemente ligada à estimulação sináptica e que as suas proteínas podem ter participação em aspectos importantes do funcionamento normal da célula, embora os papéis fisiológicos precisos das proteínas ainda sejam desconhecidos (Chaudhuri et al., 2000).

O oncogene 'v-fos' foi isolado do vírus FBJ-MSV (Finkel-Biskis-Jinkins murine osteogenic sarcoma virus) em 1982, e a sua versão celular 'c-fos' descrita posteriormente (Herrera \& Robertson, 1996; Herdegen \& Leah, 1998). O protooncogene $c$-fos, um dos primeiros genes de ativação imediata a ser caracterizado (Sheng \& Greenberg, 1990), codifica para a proteína Fos que, juntamente com produtos da família Jun, fazem parte de um complexo proteico que se liga ao complexo AP-1 (activator-protein 1) presente em alguns genes de ativação tardia. Essa ligação permitiria a expressão dos produtos neuronais diferenciados desses genes, como os neurotransmissores e suas enzimas de síntese (Krukoff, 1998).

A função reguladora da proliferação celular do gene $c$-fos tem sido sugerida desde a observação de sua ativação por fatores de crescimento (Sheng \& Greenberg, 1990), e atualmente há evidências da participação de seu fator de transcrição nos mecanismos moleculares relacionados à proliferação, diferenciação celular, apoptose e transformação maligna, apresentando também várias funções biológicas (desenvolvimento e homeostase do tecido, respostas celulares) e de supressão de tumores em vários tipos de cânceres (Durchdewald, Angel, \& Hess, 2009).

O gene $c$-fos tem sido o marcador de atividade neuronal do sistema nervoso central mais amplamente utilizado na pesquisa, entre outras razões, por apresentar baixos níveis de expressão em condições basais e poder ser facilmente combinado com outros tipos de marcadores (Kovács, 2008). Há evidências que indicam que a expressão 
da proteína Fos pode estar estreitamente correlacionada às mudanças de longo prazo da função neuronal, de maneira que sua expressão pode ser um pré-requisito para esse tipo de alteração tanto nos neurônios como em outros tipos de células (Kaczmarek, 2000). O papel do gene $c$-fos no armazenamento da informação no sistema nervoso central foi proposto devido à sua rápida e transiente indução e a localização de seu produto no núcleo celular (Herrera \& Robertson, 1996). Mais recentemente, a importância do gene c-fos na consolidação da memória teria sido confirmada por meio de experiências com camundongos knockout e por meio de experimentos que bloquearam a tradução do seu RNA mensageiro (Kubik, Miyashita, \& Guzowski, 2007).

O gene egr-1 (também denominado de zif268, zenk, krox-24, TIS-8 e NGFI-A) é o membro da família Egr mais amplamente estudado em processos de plasticidade sináptica em contextos que envolvam o aprendizado (Poirier, Cheval, Mailhes, Garel, Charnay, Davis, \& Laroche, 2008). O gene zif268 foi identificado por Lau and Nathans em fibroblastos de camundongos em 1987 e, no mesmo ano, o gene NGFI-A (nerve growth factor-inducible gene A) foi isolado de células de rato por Milbrandt (Herdegen \& Leah, 1998; Knapska \& Kaczmarek, 2004).

O gene egr-1 pertence à categoria dos genes de ativação imediata porque é ativado na ausência de síntese de novas proteínas e codifica um fator de transcrição que apresenta um padrão distinto de expressão no encéfalo, sendo o mesmo considerado importante porque atuaria em conjunto com outros fatores de transcrição na modulação (ativando ou reprimindo) de outros genes (Knapska \& Kaczmarek, 2004). A expressão desse gene ocorreria in vivo em neurônios maduros do sistema nervoso adulto, sendo que o papel de sua proteína ainda não está claro; ela estaria envolvida no crescimento e 
diferenciação da célula, bem como nas mudanças metabólicas e estruturais da célula neuronal madura, fazendo parte de um complicado sistema regulador (Knapska \& Kaczmarek, 2004). Muitos autores têm proposto um papel direto da proteína Egr-1 no controle da proliferação celular, aumentando (Perez-Castillo, Pipaón, García, \& Alemany, 1993; Thiel \& Cibelli, 2002) ou reduzindo a crescimento das células (Huang, Liu, Fan, Mercola, \& Adamson, 1995; Liu, Adamson, \& Mercola, 1996). Há estudos demonstrando a atuação da proteína Egr-1 na regulação da proliferação celular, aumentando ou reduzindo a progressão de tumores (Calogero, Lombari, De Gregorio, Porcellini, Ucci, Arcella, Caruso, Gagliardi, Gulino, Lanzetta, Frati, Mercola, \& Ragona, 2004).

Estudos recentes mostram que o gene egr-1 é ativado após a estimulação tetânica indutora da potenciação de longo prazo, e que essa ativação seria essencial para a ocorrência de alterações plásticas neuronais na transição das memórias de curto para longo prazo (Jones, Errington, French, Fine, Bliss, Garel, Charnay, Bozon, Laroche, \& Davis, 2001), participando deste modo do mecanismo celular que preservaria as lembranças de forma duradoura (Davis et al., 2003; Bruel-Jungerman, Davis, Rampon, \& Laroche, 2006).

A expressão do gene de ativação imediata $\operatorname{egr}-1$ tem sido considerada essencial para a sobrevivência de memórias aversivas condicionadas, com estudos comportamentais e eletrofisiológicos realizados em camundongos mutantes (Jones et al., 2001) evidenciando de maneira direta o envolvimento do gene egr-l na plasticidade sináptica e memória (Bozon, Davis, \& Laroche, 2002). A participação do gene egr-1 nos mecanismos de plasticidade sináptica e consolidação da memória foi confirmada, por 
exemplo, por meio da deleção funcional do gene em camundongos testados em labirinto aquático (Kubik et al., 2007). Assim, ainda que os mecanismos moleculares específicos não estejam ainda definidos em razão da não identificação dos genes alvos no encéfalo, considera-se ser clara a função mediadora da proteína Egr-1 na expressão de genes em alguns processos de aprendizado e memória (Li, Carter, Gao, Whitehead, \& Tourtellotte, 2005).

Na presença de estimulação extracelular, as proteínas expressas pelos genes $c$-fos e egr-1 seriam as primeiras a aparecer após uma série de eventos que podem incluir a ligação do glutamato a receptores NMDA, ativação de canais de cálcio sensíveis a voltagem após despolarização da membrana, com consequente influxo de $\mathrm{Ca}^{2+}$ na célula e ativação de quinases que resultariam na produção de outros fatores de transcrição como o CREB (Chaudhuri, 1997; Chaudhuri et al., 2000). Estes fatores ativariam as regiões promotoras dos genes $c$-fos e egr-1 no núcleo da célula, produzindo o RNA mensageiro que, no citoplasma, daria origem às proteínas Fos e Egr-1. Essas proteínas, de volta ao núcleo, teriam influência sobre a expressão dos genes de resposta tardia (Chaudhuri, 1997).

Acredita-se que tanto o gene $c$-fos quanto o egr-1 participem de processos que envolvam a aprendizagem (Herdegen \& Leah, 1998; Tischmeyer \& Grimm, 1999; Davis et al., 2003; Kubik et al., 2007), ainda que a ativação do gene c-fos aparentemente não seja necessária para a potenciação de longo prazo, nem seja per se relacionada ao estresse, excitação ou estimulação sensória (Herrera \& Robertson, 1996). A expressão aumentada do gene $c$-fos tem sido detectada em resposta a uma variedade de estímulos, incluindo a potenciação de longo prazo, mas a sua associação a tantos tipos de 
estimulação leva à possibilidade de que a sua expressão seja relacionada à atividade neuronal e não à plasticidade sináptica (Alberini, 2009).

\subsection{MEMÓRIA E APRENDIZAGEM}

Diversas são as definições existentes para os termos memória e aprendizagem. Se em Análise do Comportamento memória refere-se a comportamentos controlados por experiências que ocorreram no passado (Jans \& Catania, 1980), ou seja, comportamentos aprendidos, nessa perspectiva pesquisar memória seria investigar os processos envolvidos na aquisição do comportamento, bem como na redução do seu controle pelas contingências passadas (Branch, 1977). Alguns analistas do comportamento distinguem memória de aprendizagem, tal qual Staddon (2003) que define que aprendizagem seria uma mudança no comportamento que ocorre com o tempo e a experiência, e memória um efeito de um evento que ocorreu no passado no comportamento futuro, uma mudança de estado causada por um estímulo associado a um evento que ocorreu previamente. Em uma perspectiva neurofisiológica cognitivista, o termo aprendizagem refere-se à aquisição de informação que decorre da experiência individual, em geral como resultado de um processo e não de uma mudança instantânea, enquanto memória refere-se à persistência da informação no sistema nervoso ao longo do tempo (Howard, 1995). Na definição de Kandel, Schwartz, e Jessell (2000) tanto a memória quanto a aprendizagem são processos. A memória seria o processo pelo qual o conhecimento é codificado, armazenado e posteriormente lembrado, e a aprendizagem o processo pelo qual o conhecimento é adquirido. Já Vanderwolf (2007) coloca que, “em 
termos comportamentais, aprendizagem e memória referem-se ao estabelecimento de mudanças adaptativas duradouras no comportamento que dependem da experiência que ocorre no tempo de vida de um indivíduo" 9 e que "em termos neurocientíficos, aprendizagem e memória referem-se ao estabelecimento e manutenção de mudanças dependentes da experiência na transmissão sináptica no sistema nervoso" ${ }^{10}$ (p. 67).

Do ponto de vista neurofisiológico, geralmente analisa-se a memória como um processo complexo que depende de diversas estruturas neuro-anatômicas, sendo didaticamente classificada em estágios, dos quais os principais seriam a aquisição, a consolidação e a evocação (Abel \& Lattal, 2001). Jans e Catania (1980) consideram que o episódio do lembrar incluiria ao menos três componentes, denominados na pesquisa da memória humana, de armazenamento, retenção e evocação.

Uma das funções do cérebro parece ser a de propiciar a adaptação do organismo ao ambiente, adaptação essa que se faz por meio do constante aprendizado. Os eventos aversivos normalmente deveriam ser adaptativos, entretanto, algumas vezes podem contribuir para o aparecimento de distúrbios psicológicos nos indivíduos, o que torna muito importante o entendimento dos princípios comportamentais e mecanismos neurais do aprendizado em condições aversivas (Kim \& Diamond, 2002; Maren, 2003; Akirav \& Maroun, 2007).

Os neurobiologistas atualmente acreditam que já compreendem como novas memórias são formadas, mas que ainda não descobriram como as mesmas se tornam

\footnotetext{
${ }^{9}$ Traduzido do original "In behavioral terms, learning and memory refer to the establishment and maintainance of long-lasting experience-dependent adaptive changes in behavior occurring within the lifetime of one individual"

10 Traduzido do original "In neuroscientific terms, learning and memory refer to the establishment and maintainance of experience-dependent changes in synaptic transmission in the nervous system".
} 
permanentes (Izquierdo \& Cammarota, 2004; Frankland \& Bontempi, 2005). Em outras palavras, supõe-se que os mecanismos celulares pelos quais as experiências são retidas pelo organismo no curto prazo já sejam conhecidos, embora ainda não tenham sido descobertos os mecanismos que promovem a retenção no longo prazo, mecanismos esses que levariam à persistência das respostas aos estímulos associados à experiência. Independentemente disso, está se tornando evidente que o processo necessário para assegurar a permanência das mesmas é tempo-dependente (Izquierdo \& Cammarota, 2004; Wiltgen, Brown, Talton, \& Silva, 2004).

Os neurocientistas referem-se com frequência à teoria de consolidação, que defende que há dois tipos de consolidação necessários à estabilização da memória, isto é, dois tipos de mudanças morfológicas nos circuitos sinápticos para que a experiência seja retida pelo organismo. O primeiro tipo de modificação morfológica, a consolidação sináptica, mais rápida, envolveria a estabilização de alterações nas conexões sinápticas de circuitos localizados. As mudanças morfológicas nos circuitos hipocampais seriam um exemplo deste tipo de consolidação. A ativação sináptica decorrente do estímulo iniciaria uma cascata neuroquímica que provocaria a ativação de segundo mensageiros, de fatores de transcrição e síntese das proteínas necessárias às mudanças estruturais (Frankland \& Bontempi, 2005; Bruel-Jungerman et al., 2006). Segundo Alberini (2008) há evidências fortes e consistentes que levam à conclusão de que a síntese de proteínas específicas é essencial para a ocorrência de plasticidade sináptica duradoura e formação da memória de longo prazo (Bozon et al., 2002).

O segundo tipo de alteração, a consolidação no sistema, envolveria a reorganização sináptica em regiões encefálicas corticais específicas, e ocorreria de uma maneira mais prolongada e gradual (Frankland \& Bontempi, 2005). Esse processo, no 
qual o córtex pré-frontal parece ter um papel privilegiado, pode seguir um princípio geral entre as espécies (Frankland \& Bontempi, 2005). A teoria de consolidação assume que a sucessiva reativação da rede de conexões hipocampo-corticais, que ocorreria de forma rápida e temporária, teria como consequência um progressivo, mas lento e duradouro, fortalecimento das conexões entre as áreas corticais, o que permitiria que novas memórias se tornassem independentes do hipocampo ao serem gradualmente integradas às regiões corticais (Wiltgen et al., 2004; Frankland \& Bontempi, 2005).

Outra teoria, proposta em 1997 e denominada de teoria dos múltiplos traços $^{11}$, defende que a reativação das memórias (isto é, o comportamento de lembrar/recordar) iniciaria um processo de reorganização das conexões sinápticas também no hipocampo, e não somente nas redes corticais como defende a teoria da consolidação (Frankland \& Bontempi, 2005). A possibilidade de que a ocorrência de diferentes formas de plasticidade resulte nas diferenças que têm sido observadas entre o hipocampo e o neocórtex, inclusive na formação de novas conexões entre neurônios anteriormente não conectados, também existe (Frankland \& Bontempi, 2005). Uma nova hipótese, que aventa a possibilidade de que a evocação de uma lembrança possa permitir que a mesma seja modificada, tem sido denominada de reconsolidação (Abel \& Lattal, 2001).

\subsection{O DESAMPARO APRENDIDO E OS GENES C-FOS E EGR-1}

A expressão neuronal do gene $c$-fos no modelo animal do desamparo aprendido

11 Para maiores detalhes, consultar Nadel, L., \& Moscovitch, M. (1997). Memory consolidation, retrograde amnesia and the hippocampal complex. Current Opinion in Neurobiology, 7(2), 217-227. 
tem sido o objeto de estudo de alguns artigos científicos, sendo estes caracterizados pela diversidade principalmente em relação à metodologia e/ou enfoque científico. Estudos que pesquisem a atividade neuronal do gene egr-l ou a expressão simultânea das proteínas Fos e Egr-1 no modelo do desamparo aprendido não foram encontrados. Embora a expressão dos genes c-fos e egr-1 se sobreponha ao longo do tempo (Zangenehpour \& Chaudhuri, 2002), características distintas em sua ocorrência têm sido observadas em outros estudos (Wisden, Errington, Williams, Dunnett, Waters, Hitchcock, Evan, Bliss, \& Hunt, 1990), tornando interessante que o estudo da expressão desses genes seja realizado de maneira simultânea. Os estudos sobre a imunorreatividade para a proteína Fos que apresentaram características mais próximas a este estudo estão descritos a seguir.

Steciuk, Kram, Kramer, e Petty (1999) examinaram a imunorreatividade para a proteína Fos em regiões do encéfalo de ratos machos expostos a procedimento para indução do desamparo aprendido. No primeiro dia do experimento, dois grupos não receberam choques. Um grupo permaneceu no biotério e o outro foi colocado nos tubos de restrição. Outro grupo de animais foi igualmente colocado em tubos de restrição, recebendo, através da cauda, 100 choques randômicos de $1 \mathrm{~mA}$, duração de 5 s. No segundo dia todos os sujeitos foram submetidos a 30 choques, ministrados no piso da caixa experimental (shuttlebox) com duração de 30 s cada. Os choques eram desligados após uma resposta de correr ao compartimento oposto da caixa (FR1) nas 5 primeiras tentativas e após duas respostas, ir e vir (FR2), nas 25 tentativas subsequentes. Os animais do grupo que recebeu choques no tratamento foi separado em dois subgrupos, um composto pelos animais que apresentaram desamparo, e outro dos que não apresentaram esse efeito, sendo essa divisão realizada pela aplicação de um critério 
baseado nas latências dos animais ingênuos no teste. No terceiro dia todos os sujeitos (ingênuo, restrição, grupos com e sem desamparo) receberam 20 minutos de choques na cauda e, duas horas após o início da sessão, foram anestesiados com pentobarbital e perfundidos. Secções coronais de 50 micrômetros $(\mu \mathrm{m})$ dos encéfalos foram obtidas em micrótomo sob congelamento, tratadas para imunodetecção de Fos por meio do método ABC Elite e revelação com diaminobenzidina (DAB). As estimativas dos núcleos positivos para Fos foram realizadas no córtex pré-frontal medial, núcleo septal lateral, núcleo paraventricular hipotalâmico, córtex amigdalóide, núcleo amigdalóide medial e núcleo amigdalóide basolateral. Os resultados evidenciaram uma maior imunorreatividade para a proteína Fos no núcleo paraventricular hipotalâmico e na amígdala para os animais ingênuos. O principal resultado encontrado foi uma significativa redução da imunorreatividade observada no núcleo septal lateral dos sujeitos do grupo com desamparo. Os autores concluíram que a área septal é importante na mediação das respostas comportamentais ao estresse inescapável.

Huang, Cheng, Hong, e Tsai (2004) pesquisaram a expressão do gene $c$-fos em camundongos machos em áreas do encéfalo consideradas de interesse para o estudo da depressão e estresse. Foram estudados três grupos de animais, um grupo controle que permaneceu na gaiola, e outros dois grupos que foram expostos a uma pré-sessão de choques $(0,6 \mathrm{~mA}, 5 \mathrm{~s}$ de duração a cada $6 \mathrm{~s})$ em uma shuttlebox. O propósito da présessão de choques nesse primeiro dia era de selecionar os animais com menos de 10 falhas em 30 tentativas. Os animais selecionados, do segundo ao quarto dia, foram presos pela cauda a uma grade de inox recebendo 300 choques nas patas $(0,6 \mathrm{~mA}, 10 \mathrm{~s}$ de duração, intervalo médio de 45 s). No quinto dia cada camundongo foi submetido ao teste de fuga (30 tentativas, 0,6 mA, $5 \mathrm{~s}$ de duração máxima, intervalo médio de $30 \mathrm{~s}$ ), 
em seguida anestesiado com pentobarbital e perfundido. Os sujeitos com mais de 20 falhas de resposta foram considerados com desamparo (LH) e aqueles com 10 ou menos falhas considerados sem desamparo (NLH). Secções coronais de $30 \mu \mathrm{m}$ obtidas em criostato foram tratadas para Fos por meio do método $\mathrm{ABC}$ Elite e reveladas com DAB. As estimativas dos núcleos imunorreativos para Fos foram efetuadas no córtex préfrontal medial, áreas CA1, CA2, CA3 e DG do hipocampo, núcleo septal lateral, núcleo accumbens, amígdalas basolateral e central, e núcleo hipotalâmico paraventricular. Os resultados mostraram uma menor imunorreatividade no giro denteado do hipocampo, no córtex pré-frontal medial e no núcleo septal lateral para o grupo LH na comparação com o grupo NLH e uma maior imunorreatividade no CPFm para os sujeitos NLH em comparação com o grupo controle. Também foi encontrada uma maior imunorreatividade no núcleo paraventricular hipotalâmico para o grupo LH em comparação com o grupo NLH. Os pesquisadores concluíram que o núcleo septal lateral, o núcleo paraventricular hipotalâmico e o giro denteado do hipocampo estão associados ao desenvolvimento do desamparo aprendido em camundongos.

Castro-Alamancos, Borrell, e Garcia-Segura (1992) investigaram a expressão do gene $c$-fos no córtex motor e no hipocampo de ratos machos. O objetivo dos autores deste trabalho era estudar os efeitos do aprendizado sob estimulação aversiva onde a resposta de pressão à barra desligava o choque (fuga). Os animais foram divididos em três grupos. O grupo controle participou de todo o experimento, porém sem levar choques. Os outros dois grupos, um que podia desligar o choque (TR) e o outro acoplado (YK), participaram de treinamento sob contingência de esquiva sinalizada com duas luzes, uma de cada lado da barra, com uma sessão por dia durante 6 dias consecutivos. $\mathrm{O}$ animal acoplado recebia choques da mesma intensidade, duração e frequência que o 
animal do grupo TR, sem a possibilidade de desligá-los. A cada sessão os animais foram expostos a 30 tentativas espaçadas entre si por $5 \mathrm{~s}$, cada uma iniciando com as luzes que permaneciam por $3 \mathrm{~s}$ seguidas de um choque $(0,3 \mathrm{~mA})$ liberado através do piso da caixa experimental por $15 \mathrm{~s}$. Se a resposta de pressão à barra ocorresse durante as luzes, elas eram desligadas e o choque não era apresentado (esquiva). Caso a resposta não ocorresse no período de $3 \mathrm{~s}$ de luz, o choque era liberado, podendo ser desligado com a resposta de pressão à barra ou, em sua ausência, após $15 \mathrm{~s}$ do início do choque, iniciando-se novo intervalo entre tentativas. No sétimo dia esses animais foram expostos à mesma contingência, desta vez com 50 tentativas, enquanto o animal controle permanecia na caixa, sem levar choques. Três horas após a sessão, todos os animais foram anestesiados com pentobarbital e perfundidos. Secções coronais de $70 \mu \mathrm{m}$ obtidas em micrótomo foram submetidas à reação para Fos (Fos-like) utilizando o método ABC Elite e revelação com $\mathrm{DAB}$. Os resultados evidenciaram maior imunorreatividade nas áreas motoras, mas o resultado não mostrou diferenças significantes no giro denteado do hipocampo entre os grupos TR e YK. Os autores chegaram à conclusão de que a expressão do gene $c$-fos no giro denteado do hipocampo se deve à apresentação de estímulos sensoriais e não a ativação específica associada a processos de memória e aprendizagem. 


\section{OBJETIVOS}

O propósito principal do presente experimento foi investigar os padrões de ativação neuronal em diferentes áreas do encéfalo de ratos submetidos ao modelo do desamparo aprendido, avaliando se a imunorreatividade para as proteínas Fos e Egr-1 está diferencialmente alterada quando é constatada a não aprendizagem como função de choques incontroláveis (desamparo aprendido). O experimento examinou a ativação neuronal na amígdala, córtex pré-frontal medial e hipocampo, que são citadas na literatura como funcionalmente importantes para os mecanismos neurobiológicos da memória e aprendizagem, em razão das evidências da participação dos genes $c$-fos e $e g r$ 1 em tais mecanismos. Também foi examinada a ativação neuronal no núcleo septal lateral, estrutura associada ao desamparo aprendido por Steciuk et al. (1999) e Huang et al. (2004).

Os objetivos específicos deste trabalho foram de analisar (1) as estimativas do número de núcleos imunorreativos para as proteínas Fos e Egr-1 no hipocampo, córtex pré-frontal medial, amígdala e núcleo septal lateral, e as possíveis alterações decorrentes da exposição aos choques inescapáveis; (2) as estimativas do número de núcleos imunorreativos para a proteína Egr-1 comparativamente aos dados obtidos para a proteína Fos nas estruturas ou áreas estudadas; (3) os resultados significantes de imunorreatividade para a proteína Fos comparativamente aos resultados publicados em outros estudos que tenham em comum com este trabalho o gene marcador de ativação neuronal, as áreas encefálicas e o modelo animal. 


\section{MÉTODO}

\subsection{SUJEITOS}

Foram utilizados 50 ratos albinos (Rattus norvegicus) da linhagem Wistar, machos, experimentalmente ingênuos, provenientes do biotério do Instituto de Ciências Biomédicas da Universidade de São Paulo (ICB/USP). Os animais foram transportados para o biotério do Instituto de Psicologia da Universidade de São Paulo (IP/USP) com a idade aproximada de 45 dias, sendo mantidos em gaiolas coletivas até a idade aproximada de 90 dias, quando foram transferidos para gaiolas suspensas individuais. Esse biotério funcionava com sistema de controle da temperatura ambiente $\left(22 \pm 1{ }^{\circ} \mathrm{C}\right) \mathrm{e}$ renovação contínua do ar, com ciclo de 12 horas luz/escuro (7 às 19 horas). Os sujeitos foram identificados, pesados e mantidos em suas gaiolas por um período mínimo de 7 dias antes do início dos procedimentos experimentais, que ocorreram durante o período de luz. As sessões de tratamento e teste de fuga foram realizadas entre 8 e 14 horas. Os animais foram alimentados com ração seca balanceada (Nuvital ${ }^{\circledR}$ ) e água ad libitum. Pesagens semanais foram realizadas com a finalidade de acompanhar a saúde dos sujeitos. Os procedimentos experimentais utilizados neste trabalho, identificado sob o número de protocolo 010/2008, foram aprovados pela Comissão de Ética em Pesquisa com Animais (CEPA) do Instituto de Psicologia da Universidade de São Paulo (Anexo A). 


\subsection{EQUIPAMENTOS}

\subsubsection{Desamparo Aprendido}

Para a realização do procedimento de indução do desamparo aprendido, que ocorreu no Laboratório de Análise Biocomportamental (IP/USP), foram utilizados dois tipos de caixas experimentais. A caixa utilizada no tratamento era cúbica, medindo 21,5 X 21,5 X 21,5 cm (comprimento, largura e altura), com a parte frontal em acrílico transparente e as demais em alumínio, apresentando um orifício de $3 \mathrm{~cm}$ de diâmetro localizado a $6 \mathrm{~cm}$ do piso na sua parede lateral direita. $O$ piso dessa caixa era composto por barras de latão de $0,3 \mathrm{~mm}$ de diâmetro, distantes $1,3 \mathrm{~cm}$ entre si, conectadas a um estimulador elétrico (Solid State Shocker Scrambler) Lehig Valley 113-33. Ao ser acionado o estimulador de choques, o piso dessa caixa se tornava eletrificado.

A caixa utilizada nos testes de aprendizagem, usualmente denominada de shuttlebox, era alongada, medindo 50,0 X 15,5 X 20,0 cm (comprimento, largura e altura). Essa caixa, que pode ser observada na Figura 1, era construída em acrílico preto fosco, excetuando a parede frontal que era transparente. Uma divisória de acrílico dividia a caixa em dois compartimentos de medidas iguais. Na divisória, um orifício de $7,5 \mathrm{~cm}$ de altura e $6,0 \mathrm{~cm}$ de largura nesta parede, localizada a $8,0 \mathrm{~cm}$ acima do piso, possibilitava ao animal passar de um compartimento ao outro por meio da resposta de saltar. O piso de ambos os compartimentos, bem como a superfície inferior do orifício da divisória, eram constituídos de barras de latão de $0,3 \mathrm{~mm}$ de diâmetro, distantes 1,3 cm entre si, conectadas a um gerador de choques elétricos em corrente alternada, ligado a um alternador de polaridades (shock scrambler), ambos de marca BRS Foringer, 
modelo 901. Os pisos dos dois compartimentos podiam ser inclinados nos extremos da caixa, com movimentos independentes entre si. Como o piso de cada compartimento era sustentado por molas laterais, o peso do rato promovia a inclinação apenas do piso do compartimento no qual ele se encontrava. Essa inclinação acionava um microswitch que registrava automaticamente a sua presença nesse compartimento. Os choques eram liberados nas barras da divisória e no piso do compartimento onde o animal estivesse situado. Dessa forma, ao transpor a barreira divisória e chegar no compartimento oposto, o animal tocava em piso não eletrificado.

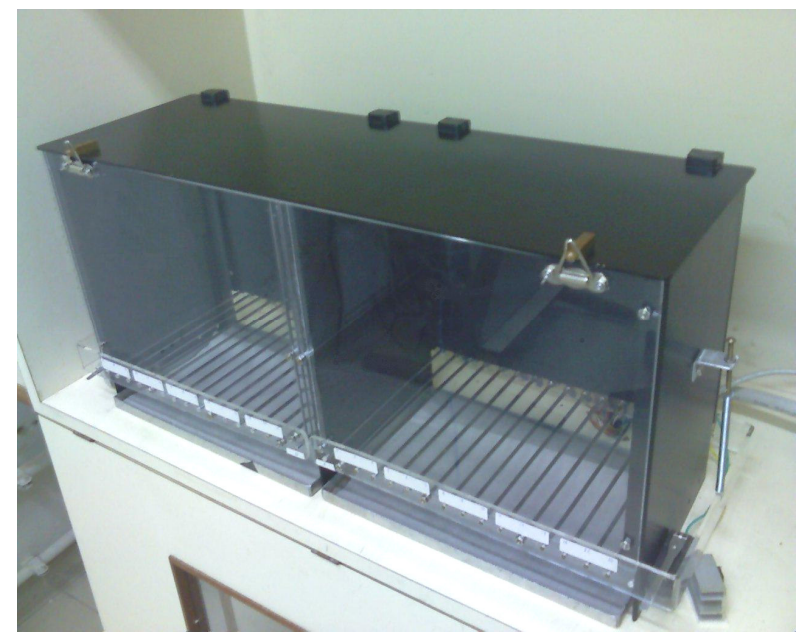

Figura 1 - Caixa de teste de aprendizagem de fuga (shuttlebox) utilizada durante o experimento. A caixa distingue-se das usualmente citadas na literatura em função do orifício que permite a passagem entre os compartimentos ser elevado, exigindo a resposta de saltar, ao invés da resposta de correr registrada nas caixas onde a abertura fica ao nível do piso (ver Hunziker \& Santos, 2007).

A umidade do ar no laboratório onde os experimentos ocorreram foi mantida automaticamente entre 40 e $70 \%$ por meio de um desumidificador Arsec Mod 160 M3$U$, e o valores de umidade aferidos com o uso de um higrômetro (Präzisions 
Hygrometer, West Germany). Um equipamento de ar condicionado mantinha a temperatura ambiente.

O controle e os registros de dados das sessões foram realizados por um microcomputador 486 IBM (International Business Machines Corp., Armonk, NY, USA) controlado por programa em linguagem Delphi 6.0 (Borland Software Corp., Scotts Valley, CA, USA), especialmente desenvolvido para este tipo de pesquisa.

\subsubsection{Perfusão Transcardíaca}

O procedimento de perfusão transcardíaca foi realizado em capela de exaustão com a utilização de uma bomba de pressão Masterflex ${ }^{\circledR}$ (Cole Parmer Instrument Company., Chicago, IL, USA) e instrumentos cirúrgicos.

\subsubsection{Imuno-histoquímica}

As secções dos encéfalos foram obtidas por meio de micrótomo de deslizamento Leica $^{\circledR}$ SM 2000R (Leica Instruments, Germany). Durante o tratamento imunohistoquímico, as secções foram lavadas sob agitação em mesas agitadoras de Kline modelo NT 151 (Nova Técnica, Piracicaba, SP, Brasil) e incubadas em rotor RotoTorque $^{\circledR}$ modelo 7637 (Cole-Parmer Instrument Company, Chicago, IL, USA). Visando sua preservação, os materiais foram mantidos a $4{ }^{\circ} \mathrm{C}$ em refrigeradores (Metalfrio, São Paulo, SP, Brasil), ou em solução antifreeze a $-20^{\circ} \mathrm{C}$ em freezer Electrolux ${ }^{\circledR}$ modelo FE22 (Electrolux, São Paulo, SP, Brasil), a $-70^{\circ} \mathrm{C}$ em freezer $\mathrm{REVCO}^{\circledR}$ (Thermo Fisher Scientific Inc., Waltham, MA, USA), ou a $-80^{\circ} \mathrm{C}$ em freezer NuAire ${ }^{\circledR}$ (NuAire Inc., Plymouth, MN, USA). As secções dos encéfalos foram montadas sobre lâminas 
gelatinizadas e secas em placa quente a $40^{\circ} \mathrm{C}$ (Slide Warmer Fisher Scientific, Pittsburg, $P A, U S A)$. As reações para revelação dos núcleos imunorreativos, intensificação da reação e desidratação das lâminas ocorreram em capelas de exaustão adequadas para esse fim.

\subsubsection{Quantificação da Imunorreatividade}

A estimativa do número de núcleos imunorreativos foi realizada por meio de microscópio de luz Leitz Aristoplan (Leica Instruments, Germany) conectado a um microcomputador Macintosh ${ }^{\circledR}$ (Apple Computer Inc., Cupertino, CA, USA) equipado com o programa NIH Image versão 1.59 (W. Rasband, National Institutes of Health, Bethesda, MD, USA). A identificação das estruturas encefálicas foi realizada por meio de atlas estereotáxico de encéfalo de rato (Paxinos \& Watson, 2005). Imagens digitais para ilustração foram obtidas por meio de câmera digital Nikon DXM 1200 acoplada a um microscópio Nikon Eclipse E1000 (Nikon Corporation, Tokyo, JP).

\subsection{PROCEDIMENTO}

\subsubsection{Adaptação}

O experimento iniciou-se pelo período de adaptação dos animais às caixas experimentais, o que ocorreu durante três dias consecutivos. Em cada um dos três dias de adaptação, o animal era trazido do biotério para o laboratório onde permanecia durante 30 minutos na caixa a ser utilizada posteriormente no tratamento, 30 minutos na 
caixa a ser utilizada posteriormente no teste (shuttlebox) e, por último, por outros 30 minutos na sala onde posteriormente seria submetido à anestesia. Durante o tempo em que permanecia nas duas caixas o animal não era exposto a qualquer manipulação. $\mathrm{Na}$ sala de anestesia, durante os 30 minutos do período de adaptação, cada animal era manipulado da mesma forma que durante o experimento, excetuando-se a administração do anestésico, que não era simulada. Essa manipulação consistia na imobilização necessária à aplicação do anestésico e colocação na caixa de acrílico com maravalha onde, durante o experimento propriamente dito, o animal anestesiado seria transportado. Cumprido o período de 30 minutos nessa sala, o animal era recolocado em sua gaiolaviveiro e devolvido ao biotério. Esse procedimento de adaptação dos animais às condições laboratoriais e experimentais foi considerado necessário para evitar que a expressão dos genes de ativação imediata $c$-fos e egr-l ocorresse em decorrência da exposição dos animais a estímulos novos, não relacionados ao tratamento experimental em estudo (Tischmeyer \& Grimm, 1999).

\subsubsection{Indução do Desamparo Aprendido}

Os animais foram divididos em quatro grupos, sendo apenas dois deles expostos aos choques. No tratamento, os animais do grupo Incontrolável (INC) foram submetidos a 60 choques inescapáveis de 1,0 mA, com duração fixa de $10 \mathrm{~s}$, distribuídos a intervalos médios de 60 s, amplitude de variação de 10-110 s. Nesta mesma etapa os animais do grupo Ingênuo (ING) permaneceram na caixa experimental sem receber choques.

No teste, conduzido 24 horas após o início do tratamento, os animais de ambos os grupos foram expostos individualmente a uma contingência de fuga na qual 
receberam 30 choques com características iguais às dos choques anteriores, com exceção de que eram escapáveis, ou seja, eram interrompidos imediatamente após o sujeito saltar de um compartimento para o outro da caixa. Cada choque correspondia a uma tentativa, sendo o tempo decorrido entre o início e o término do choque considerado como latência da resposta na tentativa. Se a resposta de saltar não ocorresse, o choque era automaticamente desligado após $10 \mathrm{~s}$ do seu início. Neste caso, seria caracterizada uma falha. As respostas que ocorressem no intervalo entre tentativas não tinham conseqüência programada, nem eram registradas. Ao final de cada sessão, os dejetos eram retirados e a caixa experimental era limpa com toalhas de papel e solução hidroalcoólica, com a finalidade de reduzir, para o sujeito posteriormente colocado nessa caixa, os estímulos olfativos relacionados à condição de estresse à qual o sujeito anterior tinha sido submetido.

Os animais do grupo denominado Adaptação (ADA) permaneceram nas caixas experimentais durante os períodos correspondentes ao tratamento e ao teste, porém sem receber choques. Os animais do grupo denominado Biotério (BIO) permaneceram no biotério durante essas etapas.

\subsubsection{Anestesia}

Imediatamente após o teste de fuga os animais eram levados para a sala de anestesia onde uma mistura de cetamina $\left(10 \mathrm{mg} / \mathrm{kg}\right.$, Dopalen ${ }^{\circledR} 116 \mathrm{mg} / \mathrm{mL}$, Vetbrands) e xilazina ( $8 \mathrm{mg} / \mathrm{kg}$, Anasedan ${ }^{\circledR} 23 \mathrm{mg} / \mathrm{mL}$, Vetbrands) era administrada uma hora após o início do teste. Uma vez sedados, os animais eram transportados para o Laboratório de Neurobiologia Celular (ICB/USP) para que procedimento de perfusão transcardíaca 
pudesse ser realizado e o encéfalo extraído. Todos os animais, incluindo os sujeitos dos grupos $\mathrm{BIO}$ e ADA, foram anestesiados, perfundidos e seus encéfalos coletados para posterior utilização.

\subsubsection{Perfusão Transcardíaca}

Após a chegada do animal ao Laboratório de Neurobiologia Celular (ICB/USP), se necessária, era administrada dose adicional de anestésico intraperitoneal (cetamina + xilazina) e/ou por inalação (halotano, Tanohalo ${ }^{\circledR}$, Cristália), para que a perfusão transcardíaca fosse realizada durante anestesia profunda, garantindo a não ocorrência de sofrimento para o animal.

Logo no início da perfusão os animais recebiam injeção intracardíaca do anticoagulante heparina (Liquemine ${ }^{\circledR} 5.000$ UI/mL, Roche). Em seguida, eram perfundidos com $400 \mathrm{~mL}$ de solução fisiológica tamponada $(\mathrm{NaCl}$ 0,9\%, pH 7,4) e 400 mL de solução de paraformaldeído (PFA) a 4\% em tampão fosfato $0,1 \mathrm{M}(\mathrm{PB} ; \mathrm{pH} 7,4)$ visando à preservação do encéfalo. Após a perfusão das soluções, os encéfalos eram extraídos e pós-fixados por 4 horas em PFA 4\%. Essa solução era então substituída por sacarose $30 \%$ em $\mathrm{PB} \quad 0,1 \mathrm{M}$ a $4^{\circ} \mathrm{C}$ para assegurar crioproteção. Os encéfalos permaneceram em solução de sacarose sob refrigeração até serem seccionados.

\subsubsection{Critérios de Seleção}

Considerando-se que a literatura descreve que alguns animais apresentam falhas de aprendizagem mesmo sem serem submetidos a choques inescapáveis, não sendo esse o padrão típico dos animais ingênuos (Maier e Seligman, 1976; Hunziker, 2003), foram 
selecionados para a etapa seguinte da pesquisa apenas os sujeitos do grupo ING que apresentaram evidências de aprendizagem de fuga. Como essa aprendizagem é caracterizada pela redução sistemática das latências da resposta de fuga ao longo da exposição sucessiva ao reforçamento negativo, foram adotados os seguintes critérios para selecionar os sujeitos que aprenderam: (1) latências menores que 5 s no teste de fuga em pelo menos 20 das 30 tentativas, (2) e/ou latência média individual menor que 6 s nas 30 tentativas (isto é, a adição de um desvio de $10 \%$ da latência máxima por tentativa à latência média de corte mencionada anteriormente) com latências decrescentes ao longo do teste, sendo essa tendência analisada através de regressão linear.

Os animais do grupo INC também tiveram o seu padrão de aprendizagem analisado e, de acordo com o desempenho no teste de fuga, foram divididos entre dois novos grupos: desamparo (DES) e não desamparo (NDE). Foram selecionados como tendo evidências de desamparo aprendido (DES) os animais que mostraram: (1) $20 \mathrm{ou}$ mais tentativas com latência maior ou igual ao valor da soma da latência média do grupo ING adicionado ao desvio padrão dessa média, (2) e respostas cujas latências apresentassem linha de tendência ascendente ou estável ao longo da sessão de fuga, sendo essa tendência também analisada através de regressão linear. Foram agrupados como NDE os sujeitos que não preencheram os critérios estabelecidos para inclusão no grupo DES, desde que apresentassem (1) latência média individual maior ou igual ao valor da soma, porém com tendência decrescente em análise de regressão linear, (2) ou latência média individual menor que valor da média das latências do grupo ING adicionada ao desvio padrão. Os encéfalos dos animais do grupo INC que não atingiram 
os critérios para inclusão no grupo DES ou NDE não foram utilizados nas fases posteriores do experimento.

\subsubsection{Imuno-histoquímica}

Secções coronais dos encéfalos congelados por contato com placa circundada por gelo seco, com 30 micrômetros $(\mu \mathrm{m})$ de espessura, foram obtidas com o auxílio do micrótomo de deslizamento. As secções foram lavadas sob agitação em solução de tampão fosfato (PB) $0,1 \mathrm{M}$ por três vezes, 10 minutos a cada vez, antes de serem incubadas por 12 a 16 horas (overnight) à temperatura ambiente $\left(22^{\circ} \mathrm{C}\right)$ com os anticorpos policlonais de coelho contra a proteína Fos (Calbiochem, EMD Biosciences, Inc. La Jolla, CA, USA) e Egr-1 (Santa Cruz Biotechnology, Santa Cruz, CA, USA). As diluições dos anticorpos primários foram, respectivamente, 1:2.000 - 1:1.000 e 1:500 em Triton X-100 0,3\% em PB 0,1 M. Ao término de cada etapa da reação de imunohistoquímica foram realizadas novas lavagens com PB 0,1M. A seguir, as secções foram incubadas por 2 horas com anticorpo secundário anti-coelho biotinilado (Vector Laboratories, Burlingame, CA, USA) diluído 1:200 em Triton X-100 0,3\% em PB 0,1 M e, posteriormente, incubadas por mais 2 horas com o complexo avidina-biotinaperoxidase (ABC Elite kit, Vector Laboratories, Burlingame, CA, USA) diluído 1:100 em Triton X-100 ABC em PB 0,1M, para amplificação e posterior revelação do complexo. A revelação dos sítios antigênicos ocorreu por meio de reação do substrato cromogênico 3,3'-tetracloreto de diaminobenzidina (DAB) com peróxido de hidrogênio a $0,01 \%$, que resulta em um produto de oxidação polimérico insolúvel de cor marrom (Sita \& Bittencourt, 2007). As secções foram montadas em lâminas de vidro gelatinizadas que 
permaneceram em placa quente para secagem pelo tempo mínimo de 48 horas. Ao término desse período, as lâminas foram submetidas a banho de intensificação em tetróxido de ósmio $0,05 \%$ em água e, em seguida, banhos para desidratação em bateria de álcool (a 70\%, a 90\% e 100\%) e xilol. As lâminas já desidratadas foram cobertas com Permount (Fisher Scientific, Pittsburg, PA, USA) e lamínulas para proteção. Após período de secagem, quando as lamínulas estivessem firmemente aderidas, as lâminas foram limpas com xilol e disponibilizadas para observação ao microscópio.

\subsubsection{Estimativa da Imunorreatividade}

As lâminas previamente preparadas com as secções de encéfalo foram analisadas ao microscópio para identificação histológica das estruturas e determinação do tamanho e o formato das áreas a serem quantificadas. Para realização da leitura, a lâmina com as secções foi colocada no microscópio de maneira a expor a estrutura ou região de interesse na tela do monitor do microcomputador. Um retângulo ou quadrado de tamanho previamente determinado em micrômetros $(\mu \mathrm{m})$ era então posicionado sobre a mesma, sendo a leitura realizada dentro dos limites da área especificada.

O número de núcleos imunorreativos para as proteínas Fos e Egr-1 foi estimado no córtex pré-frontal medial (CPFm), hipocampo (HIP), amígdala (AMI) e núcleo septal lateral (NSL). A inclusão do NSL no estudo deveu-se aos dados publicados por Steciuk et al. (1999) em relação a esta estrutura, como citado na Introdução. No hipocampo foram realizadas estimativas em três diferentes áreas: Cornus Ammonis 1 (CA1), Cornus Ammonis 3 (CA3) e giro denteado (GD). Na amígdala as áreas selecionadas foram a amígdala central (ACe) e basolateral (ABL). As dimensões das áreas de leitura foram 
fixadas em 0,0729 $\mathrm{mm}^{2}$ para a ABL e ACe, em 0,280 $\mathrm{mm}^{2}$ para o CPFm, em 0,060 $\mathrm{mm}^{2}$ para as áreas CA1, CA3 e GD, e em 0,090 $\mathrm{mm}^{2}$ para o NSL. Para cada secção do encéfalo foram realizadas 02 (duas) leituras no CPFm, CA3, ABL, ACe e NSL, 04 (quatro) leituras no CA1, e 06 (seis) leituras no GD. Para a definição do número de leituras foi analisada a representatividade do quadrado ou retângulo em relação ao tamanho ou formato da estrutura. Os valores foram considerados válidos para posterior análise estatística se provenientes de, no mínimo, o correspondente a quatro secções do encéfalo de cada animal. Os grupos experimentais foram formados por 34 encéfalos, relativos aos grupos $\mathrm{BIO}(n=7), \operatorname{ADA}(n=6), \operatorname{ING}(n=7), \operatorname{NDE}(n=6)$ e DES $(n=8)$, conforme mostrado no Quadro I que apresenta o resumo do procedimento.

Quadro I - Representação esquemática do experimento. Grupos com ou sem adaptação, com ou sem tratamento com choques, com ou sem teste de aprendizagem de fuga. IET, intervalo entre tentativas médio; R, resposta; SN, se necessário; BIO, Biotério; ADA, Adaptação; ING, Ingênuo; INC, Incontrolável; NDE, Não desamparado; DES, Desamparado.

\begin{tabular}{|c|c|c|c|c|c|c|c|c|}
\hline Grupos & $\begin{array}{l}\text { Adaptação } \\
\left(1^{\circ}-3^{\circ} \text { dia }\right)\end{array}$ & $\begin{array}{l}\text { Tratamento } \\
\quad\left(4^{\circ} \mathrm{dia}\right)\end{array}$ & $\begin{array}{l}\text { Tempo } \\
\text { após }\end{array}$ & $\begin{array}{c}\text { Teste de } \\
\text { Aprendizagem }\end{array}$ & $\begin{array}{l}\text { Anestesia e } \\
\text { Transporte }\end{array}$ & $\begin{array}{c}\text { Obtenção } \\
\text { do }\end{array}$ & \multicolumn{2}{|c|}{$\begin{array}{c}\text { Imuno-histoquímica } \\
\text { (Fos e Egr-1) }\end{array}$} \\
\hline $\mathrm{BIO}$ & - & - & - & - & \multirow{4}{*}{$\begin{array}{c}\text { Anestesia } \\
\text { com } \\
\text { cetamina }+ \\
\text { xilazina } \\
\downarrow \\
\text { Transporte } \\
\text { em gaiola } \\
\text { acrílica } \\
\text { com } \\
\text { maravalha }\end{array}$} & \multirow{4}{*}{$\begin{array}{c}\text { Anestesia } \\
\text { cetamina } \\
+ \text { xilazina } \\
\text { e/ou } \\
\text { halotano } \\
\text { (SN) }\end{array}$} & \multirow{4}{*}{$\begin{array}{l}\text { Reação de } \\
\text { Imuno- } \\
\text { histoquímica } \\
\text { Método } \\
\text { ABC Elite }\end{array}$} & \multirow{4}{*}{$\begin{array}{l}\text { Estimativa do } \\
\text { número de } \\
\text { núcleos } \\
\text { imunorreativos }\end{array}$} \\
\hline $\mathrm{ADA}$ & \multirow{3}{*}{$\begin{array}{l}\text { Caixa de } \\
\text { Tratamento } \\
(30 \text { min) } \\
\text { Caixa de } \\
\text { Teste (30 } \\
\text { min) } \\
\text { Sala de } \\
\text { Anestesia } \\
\text { (30 min) }\end{array}$} & \multirow[t]{2}{*}{$\begin{array}{l}\text { Permanência } \\
\text { na caixa } \\
\text { experimental } \\
\text { sem choques }\end{array}$} & \multirow[t]{3}{*}{$24 \mathrm{~h}$} & $\begin{array}{l}\text { Permanência } \\
\text { na shuttlebox } \\
\text { sem choques }\end{array}$ & & & & \\
\hline ING & & & & $\begin{array}{l}30 \text { choques } \\
\text { escapáveis }\end{array}$ & & & & \\
\hline $\begin{array}{l}\text { INC } \\
\text { (NDE } \\
\text { e DES) }\end{array}$ & & $\begin{array}{c}60 \text { choques } \\
\text { inescapáveis, } \\
1 \mathrm{~mA}, 10 \mathrm{~s} \\
\text { IET } 60 \mathrm{~s} \\
(10-110 \mathrm{~s})\end{array}$ & & $\begin{array}{c}\text { 1mA, máx. 10s } \\
\text { IET } 60 \mathrm{~s}(10- \\
110 \mathrm{~s}) \\
(\mathrm{R}=\text { Fuga })\end{array}$ & & & & \\
\hline
\end{tabular}


Os grupos para análise estatística foram formados por seis sujeitos, excetuandose o grupo DES que apresentou oito sujeitos. As áreas avaliadas nos ensaios imunohistoquímicos estão sinalizadas com quadrados ou retângulos na Figura 2.

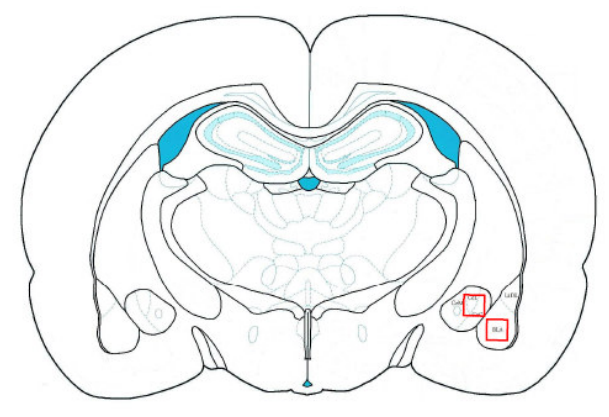

A

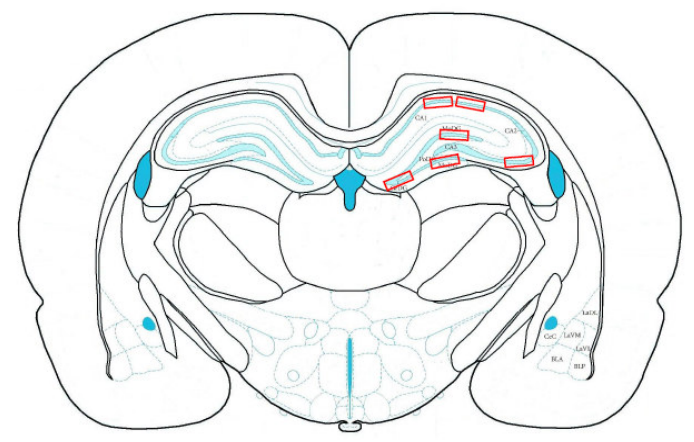

C

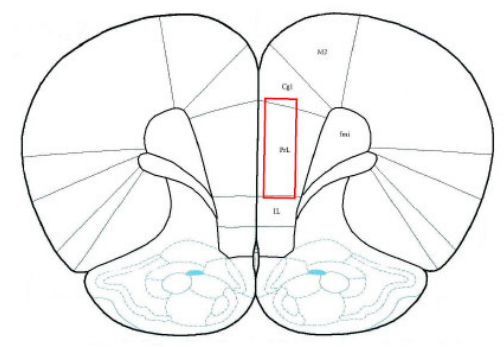

B

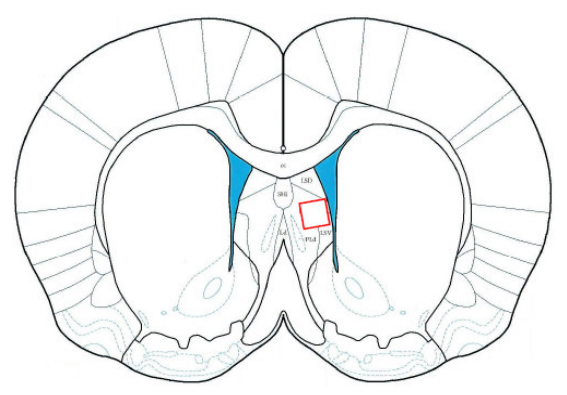

D

Figura 2 - Localização das áreas avaliadas nos ensaios imuno-histoquímicos (ilustrações modificadas de Paxinos \& Watson, 2005). A. Amígdala, central e basolateral; B. Córtex pré-frontal medial; C. Hipocampo, CA1, CA3 e giro denteado; D. Núcleo septal lateral.

\subsubsection{Análise Estatística}

A análise dos dados sobre aprendizagem de fuga foi realizada pela comparação das latências das sessões de teste apresentadas pelos animais dos grupos ING, NDE e DES. De uma maneira geral reduções sistemáticas das latências ao longo das tentativas 
caracterizaram a aprendizagem de fuga, enquanto que latências altas durante a sessão de teste caracterizaram a não aprendizagem de fuga. A diferença entre essas latências caracterizou o desamparo aprendido, sendo essa diferença determinada por meio de análise de variância de duas vias (two-way ANOVA) para medidas repetidas com teste post-hoc de Bonferroni. A análise dos dados de peso dos animais foi realizada por meio de análise de variância de uma via (one way ANOVA). O índice de significância foi estabelecido em $5 \%$.

A análise estatística dos dados sobre núcleos imunorreativos incluiu a identificação e eliminação de dados discrepantes (outliers) pela regra de Tukey $\left(\mathrm{Y}<\mathrm{Q}_{1}\right.$ $1,5 \mathrm{D}_{\mathrm{Q}}$ ou $>\mathrm{Q}_{3}+1,5 \mathrm{D}_{\mathrm{Q}}$; onde $\mathrm{Y}=$ outlier, $\mathrm{Q}_{1}=$ primeiro quartil, $\mathrm{Q}_{3}=$ terceiro quartil, $\mathrm{D}_{\mathrm{Q}}$ = distância interquartil) e análise de variância de uma via (one-way ANOVA) com posterior comparação múltipla pelo teste de Tukey-Kramer HSD. Para análise das diferenças entre duas condições também foi aplicado o teste $t$ de Student. A análise das semelhanças na distribuição dos escores foi realizada por meio do cálculo do coeficiente de correlação de Pearson. O índice de significância foi estabelecido em 5\%.

As análises estatísticas foram realizadas com a utilização dos programas GraphPad Prism 5 (GraphPad Software, San Diego, CA, EUA) e Statistica v. 8 (StatSoft Inc., Tulsa, OK, USA). 


\section{RESULTADOS}

\subsection{DESAMPARO APRENDIDO}

A Figura 3 mostra as latências médias (s), em blocos de 5 tentativas, das respostas de saltar no teste de fuga apresentadas pelos sujeitos do grupo ING. Todos os sujeitos deste grupo preencheram o critério de seleção que exigia respostas com latências menores que $5 \mathrm{~s}$ no teste de fuga em pelo menos 20 das 30 tentativas, exceto o Sujeito 5, que preencheu o critério que exigia latência média das respostas menor que $6 \mathrm{~s}$ nas 30 tentativas, e tendência decrescente das latências na análise por regressão linear (latência média $=5,87 \mathrm{~s}, \mathrm{y}=-100,17 \mathrm{x}+7420,9)$. Observa-se que a maioria dos sujeitos do grupo respondeu com latências médias mais altas no início do que no final da sessão. Com exceção dos Sujeitos 2 e 4, que apresentaram latências baixas durante toda a sessão, houve uma queda acentuada das latências do primeiro para o segundo bloco e um decréscimo mais gradual a seguir. As latências baixas ou em queda das respostas de saltar caracterizam respostas operantes controladas por reforço negativo, e esses dados indicam aprendizagem de fuga por todos os sujeitos desse grupo. 

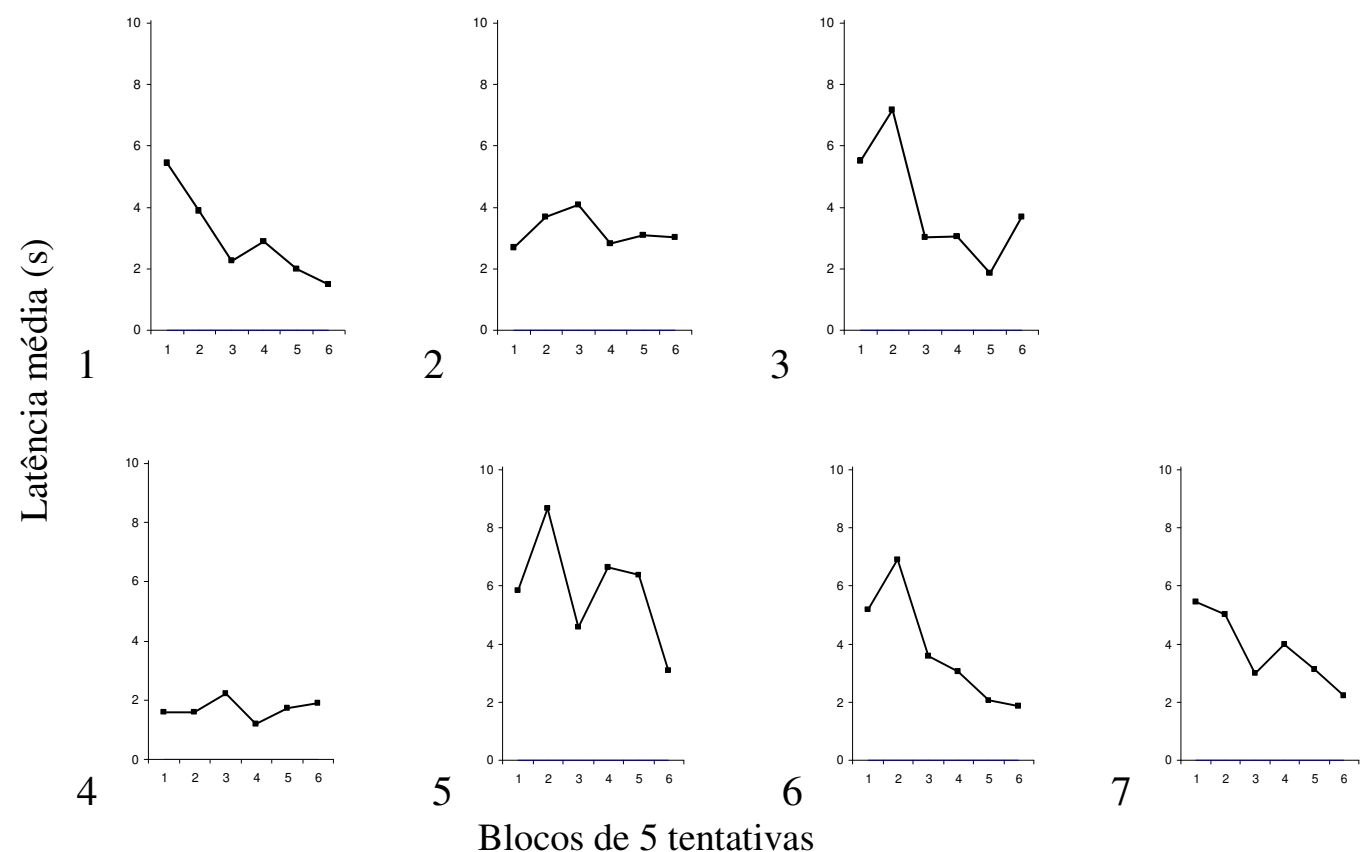

Figura 3 - Latências médias, em segundos (s), da resposta de fuga de saltar, agrupadas em blocos de 5 tentativas, apresentadas na sessão de teste pelos sujeitos do grupo ING.

Conforme descrito na seção de Método, a partir dos dados de latência das respostas dos sujeitos do grupo ING foi calculado o valor da latência média desse grupo, que foi de 3,63 s. A este valor foi adicionado o desvio padrão da média, 1,26 s. O valor da soma, 4,89 s, foi utilizado para avaliar o desempenho dos sujeitos do grupo INC no teste de fuga, alocando-os nos grupos denominados DES ou NDE. Os resultados na sessão de teste, dos sujeitos já subdivididos nesses dois grupos, são apresentados nas Figuras 4 e 5, respectivamente. 


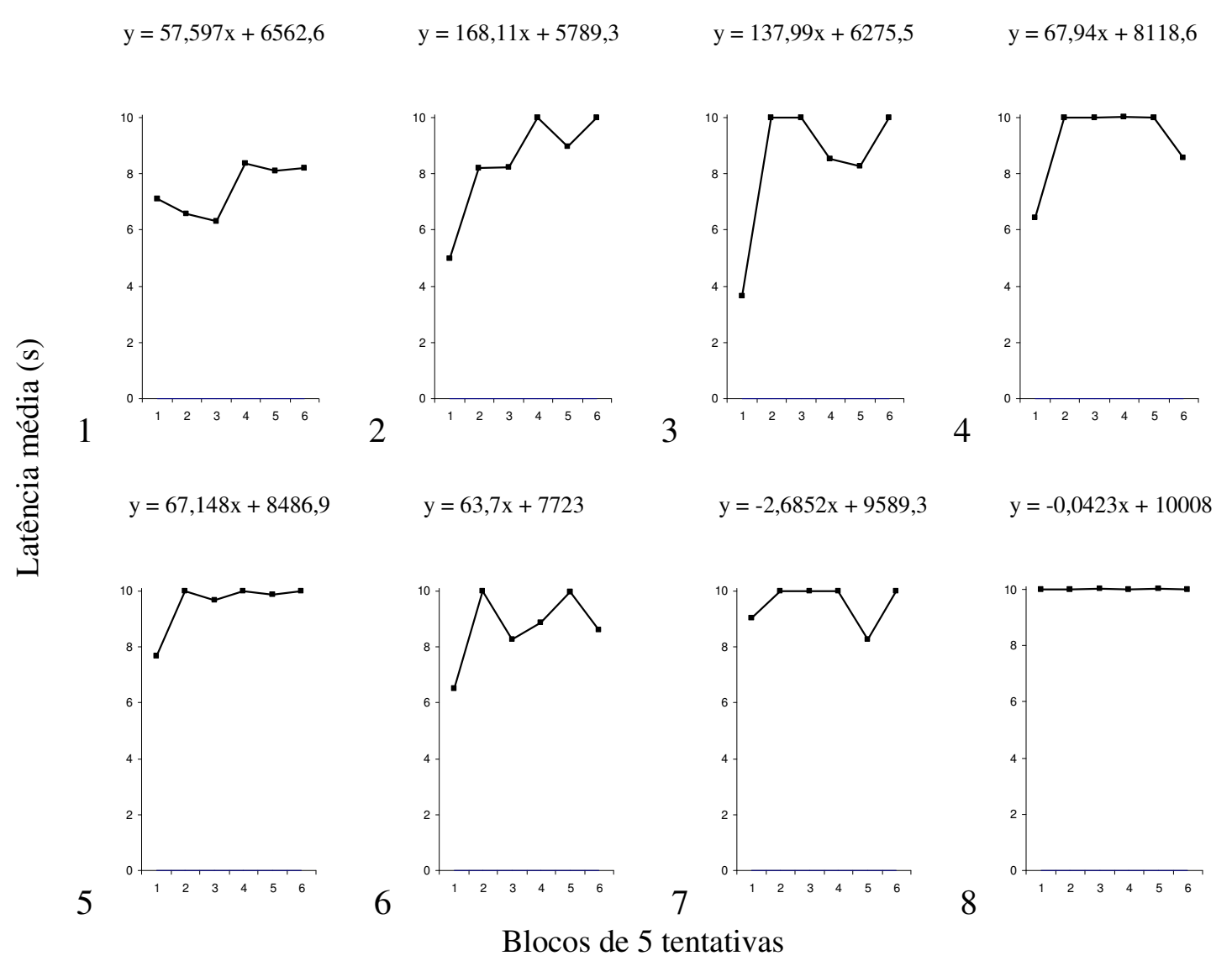

Figura 4 - Latências médias, em segundos (s), da resposta de fuga de saltar, agrupadas em blocos de 5 tentativas, apresentadas na sessão de teste pelos sujeitos do grupo DES, e as equações das retas de tendência ascendente ou estável.

A Figura 4 mostra as latências médias (s), em blocos de 5 tentativas, das respostas de saltar no teste de fuga apresentadas pelos sujeitos que preencheram os critérios para inclusão no grupo DES. Esses sujeitos apresentaram, no teste de fuga, 20 ou mais tentativas com latências maiores ou iguais a 4,89 s, latências que mostraram tendência ascendente ou estável em análise de regressão linear. As equações que definem as tendências das retas referentes ao desempenho de cada sujeito são apresentadas na parte superior do gráfico relativo ao seu desempenho. Considerando que latências de $10 \mathrm{~s}$ indicam ausência da resposta de fuga, pode-se verificar que, comparativamente aos sujeitos do grupo ING (Figura 3), os sujeitos do grupo DES 
(Figura 4) emitiram poucas respostas ao longo da sessão, ou até mesmo nenhuma resposta de fuga como ocorreu com o Sujeito 8. Nos blocos de tentativas em que respostas de fuga foram emitidas, elas ocorreram com latências médias muito elevadas, próximas ao valor máximo de 10 s. Esse desempenho caracteriza a não aprendizagem de fuga, ou seja, que a exposição ao reforço negativo não produziu redução sistemática das latências de fuga dos sujeitos do grupo DES. Os valores médios das latências dos grupos ING e DES estão disponíveis para comparação na Tabela 1 do Apêndice. Os animais que não preencheram os critérios estabelecidos para inclusão no grupo DES foram alocados no grupo NDE, exceto quando a latência média individual foi maior ou igual a 4,89 s. Nesse caso, para que a inclusão nesse grupo ocorresse, as respostas do sujeito deveriam apresentar latências sucessivas com linha de tendência decrescente em análise de regressão linear. Os animais que não preencheram os critérios para inclusão nos grupos DES ou NDE foram descartados, não participando das fases posteriores do experimento.

A Figura 5 mostra, em blocos de 5 tentativas, as latências dos sujeitos que preencheram os critérios para inclusão no grupo NDE. As equações que definem a linha de tendência decrescente das latências das respostas dos sujeitos que apresentaram latência média superior a 4,89 s (Sujeito $1=6,18 \mathrm{~s}$; Sujeito $2=5,78 \mathrm{~s}$; Sujeito $5=5,73$ s; Sujeito $6=6,03$ ) estão disponíveis na mesma figura. Observa-se que, para a maioria dos sujeitos, as latências médias das tentativas foram altas no início da sessão com queda sucessiva ao longo dos blocos de tentativas. Entre as exceções estão os Sujeitos 3 e 4 que, apesar de terem recebido choques inescapáveis no tratamento, apresentaram latências médias mais baixas que os demais sujeitos do grupo desde as tentativas iniciais, mantendo-as em patamares baixos até o final da sessão. O Sujeito 5, mesmo não 
apresentando latências em queda ao longo das tentativas, foi incluído no grupo NDE visto que preencheu os critérios estabelecidos. Esses dados mostram uma grande heterogeneidade intra-grupo das latências das respostas de fuga apresentadas ao longo das tentativas. Os valores médios das latências dos grupos NDE e DES e dos grupos ING e NDE estão disponíveis para comparação, respectivamente, nas Tabelas 2 e 3 do Apêndice.

$y=-173,24 x+8865,9$

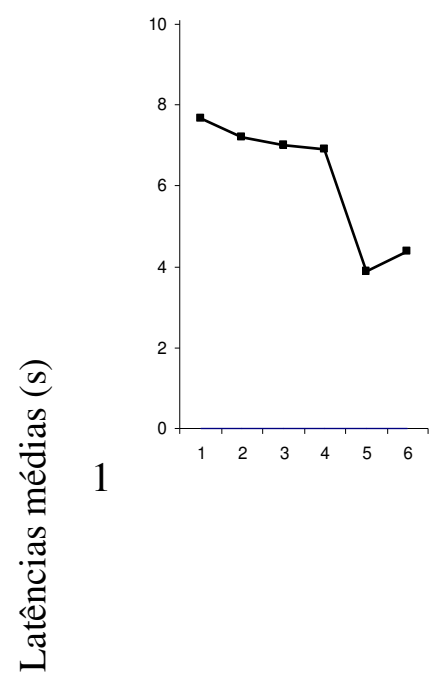

$$
4
$$

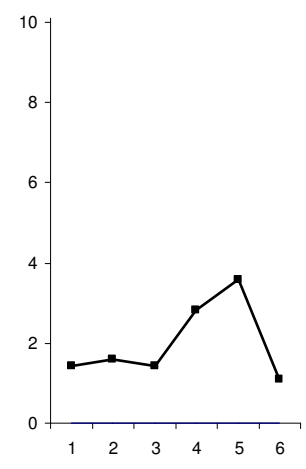

$y=-95,464 x+7258$

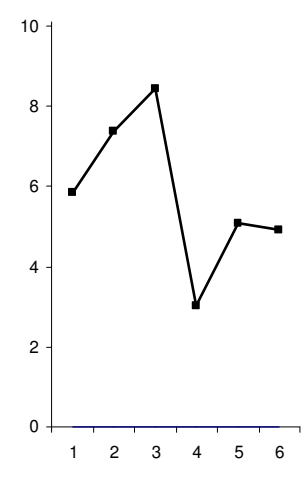

$y=-43,851 x+6408,7$

3

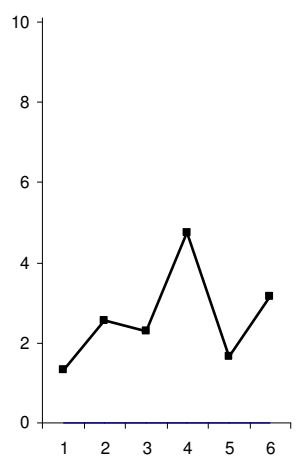

$y=-157,11 x+8460,9$

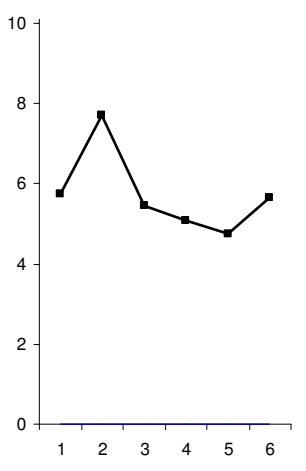

5

Blocos de 5 tentativas

Figura 5 - Latências médias, em segundos (s), da resposta de fuga de saltar, agrupadas em blocos de 5 tentativas, apresentadas na sessão de teste pelos sujeitos do grupo NDE, e as equações das retas de tendência decrescente dos sujeitos que apresentaram latência média superior a $4,89 \mathrm{~s}$. 
As latências médias de emissão da resposta de fuga saltar, apresentadas pelos três grupos, são mostradas na Figura 6. Esses dados indicam que, em média, os animais do grupo ING foram os mais rápidos durante toda a sessão de teste, acompanhados de perto pelos animais do grupo NDE, que mostram respostas com latências levemente mais elevadas em todos os blocos de tentativas. Ambos os grupos de sujeitos mostram decréscimos sucessivos das latências ao longo das tentativas, padrão esse considerado típico de aprendizagem de fuga. Diferentemente, o grupo DES apresentou latências médias ascendentes do primeiro para o segundo bloco de tentativas, e manutenção das mesmas em altos patamares durante toda a sessão. Esse padrão caracteriza a não aprendizagem de fuga.

A descrição feita por inspeção visual foi confirmada pela análise estatística. A análise de variância de duas vias para medidas repetidas (two-way ANOVA repeated measures) indicou existirem diferenças significantes no desempenho dos sujeitos nos grupos $\left(\mathrm{F}_{2,522}=32,72, \mathrm{p}<0,0001\right)$ nas latências ao longo das tentativas sucessivas $\left(\mathrm{F}_{29,522}=2,383, \mathrm{p}<0,0001\right)$, e que houve interação entre grupo e tentativas $\left(\mathrm{F}_{58,522}=\right.$ 1,461, $\mathrm{p}=0,0184)$. O teste post-hoc de Bonferroni mostrou haver diferenças significantes quando as latências do grupo DES são comparadas às latências dos grupos ING e NDE, que não diferem entre si (Apêndice, Tabelas 1- 3). Portanto, essa etapa do experimento permitiu a seleção de três tipos distintos de relação organismo/ambiente: animais ingênuos com padrão típico de aprendizagem (ING), animais que expostos a choques incontroláveis apresentaram o padrão típico de desamparo aprendido (DES) e outros que, a despeito dessa história com incontrolabilidade, aprenderam fuga normalmente, ou seja, não apresentaram o efeito de desamparo aprendido (NDE). 


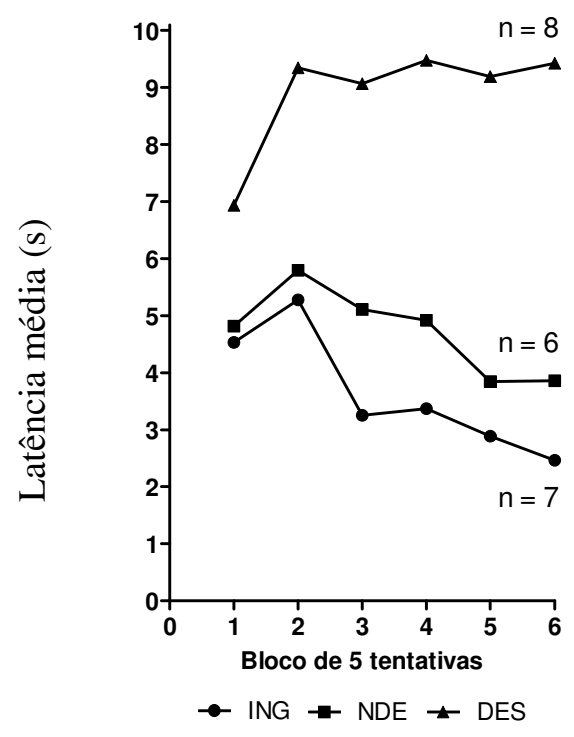

Figura 6 - Latências médias, em segundos (s), das respostas de saltar apresentadas pelos animais dos grupos ING, NDE e DES, em blocos de 5 tentativas. Os grupos diferem entre si quanto ao número de sujeitos (n indicado na figura).

Para verificar se houve algum viés em termos de peso na divisão dos animais em grupos, variável que poderia se correlacionar com as latências da resposta de saltar, a distribuição desses pesos foi também analisada. A Figura 7 mostra o peso individual de cada sujeito dos cinco grupos no dia anterior ao teste, ou o correspondente para os controles (BIO e ADA) não expostos a choques, e o peso médio ( - ) de cada grupo. O peso médio geral $( \pm \mathrm{dpm})$ para todos os sujeitos foi calculado em $386,74( \pm 69,9)$ g. A análise de variância (ANOVA) não encontrou diferenças significantes entre os pesos dos animais dos diferentes grupos que foram submetidos ao teste de fuga $\left(F_{2,18}=0,1544, p\right.$ $=0,8580$ ), indicando que, em relação a essa variável, os animais estavam distribuídos de forma equitativa entre os grupos. 


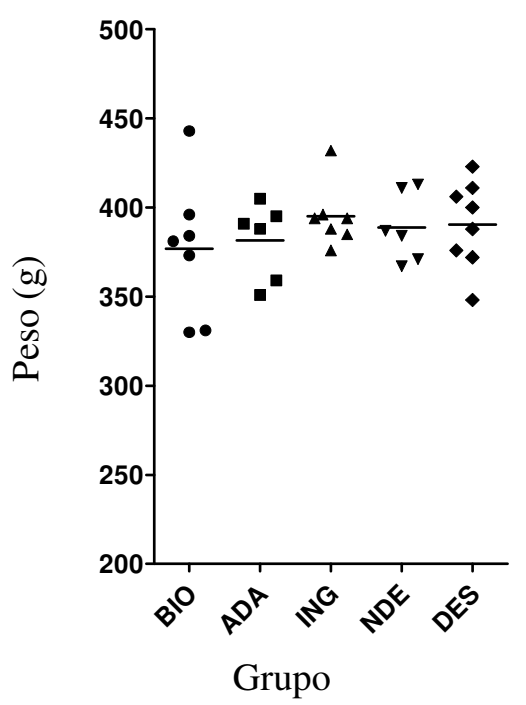

Figura 7 - Peso, em gramas (g), dos sujeitos dos grupos BIO, ADA, ING, NDE e DES no dia do tratamento ou o correspondente, e as médias (-) de cada grupo.

\subsection{EXPRESSÃO DE FOS E EGR-1}

\subsubsection{Amígdala Basolateral}

A Figura 8 mostra os valores médios de densidade de núcleos imunorreativos por milímetro quadrado de área $\left(\mathrm{mm}^{2}\right)$ para Fos e Egr-1 estimados na amígdala basolateral (ABL). No caso da imunorreatividade para Fos, o maior valor médio foi estimado para o grupo ING e o menor valor para o grupo BIO. A ANOVA de uma via (one-way ANOVA), entretanto, não indicou a presença de diferença significante entre os grupos $\left(\mathrm{F}_{4,27}=1,420, \mathrm{p}=0,2540\right) . \mathrm{O}$ maior valor médio de núcleos imunorreativos para Egr-1 na $\mathrm{ABL}$ foi encontrado no grupo DES e os menores valores médios nos grupos BIO e ING. A ANOVA indicou a presença de diferença relevante entre as médias dos grupos $\left(\mathrm{F}_{4,27}=3,449, \mathrm{p}=0,0212\right)$ sendo que a comparação múltipla pelo teste de Tukey-Kramer 
mostrou serem significantes as diferenças entre as médias dos grupos BIO e DES ( $\mathrm{p}<$ $0,05)$ e ING e DES $(\mathrm{p}<0,05)$. O teste $t$ de Student para amostras relacionadas evidenciou diferença significante $\left(t_{31}=2,545, p=0,0161\right)$ quando realizada a comparação das densidades médias totais de núcleos imunorreativos para Fos e Egr-1 estimadas na ABL, sendo a média para Egr-1 maior do que a média para Fos (ver gráfico menor).

ABL Fos

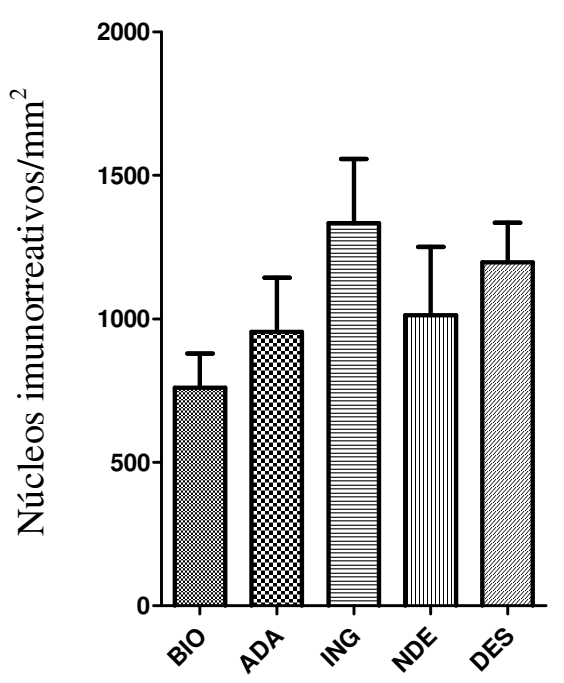

ABL Egr-1

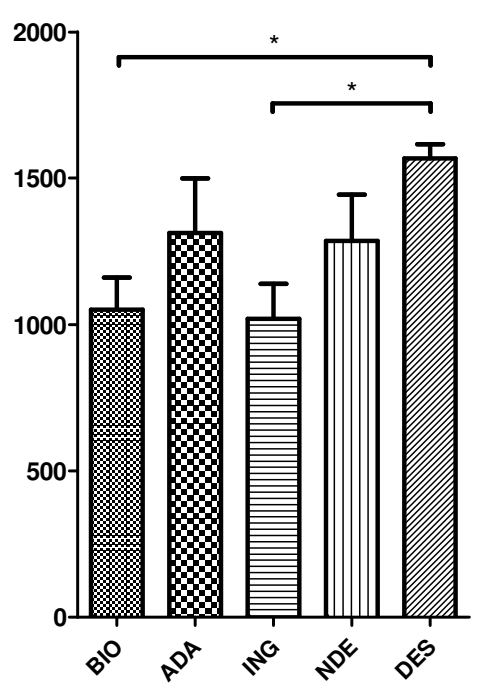

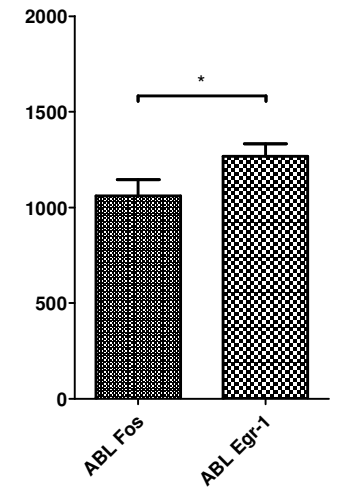

Grupo

Figura 8 - Valores médios $( \pm$ epm) de densidade de núcleos imunorreativos para Fos e Egr-1 na amígdala basolateral (ABL) dos grupos Biotério (BIO), Adaptação (ADA), Ingênuo (ING), Não Desamparado (NDE) e Desamparado (DES), e as médias totais dos marcadores para a estrutura. A análise estatística mostrou diferenças significantes na imunorreatividade para Egr-1 entre os grupos e entre as médias totais dos marcadores $(* \mathrm{p}<0,05)$.

As diferenças encontradas entre o grupo DES e os grupos BIO e ING na densidade de marcação para Egr-1 na ABL podem ser observadas nas imagens digitais da Figura 9. As duas primeiras imagens, respectivamente dos grupos BIO e ING, apresentam uma menor densidade de núcleos imunorreativos quando comparadas à imagem que representa o grupo DES. 

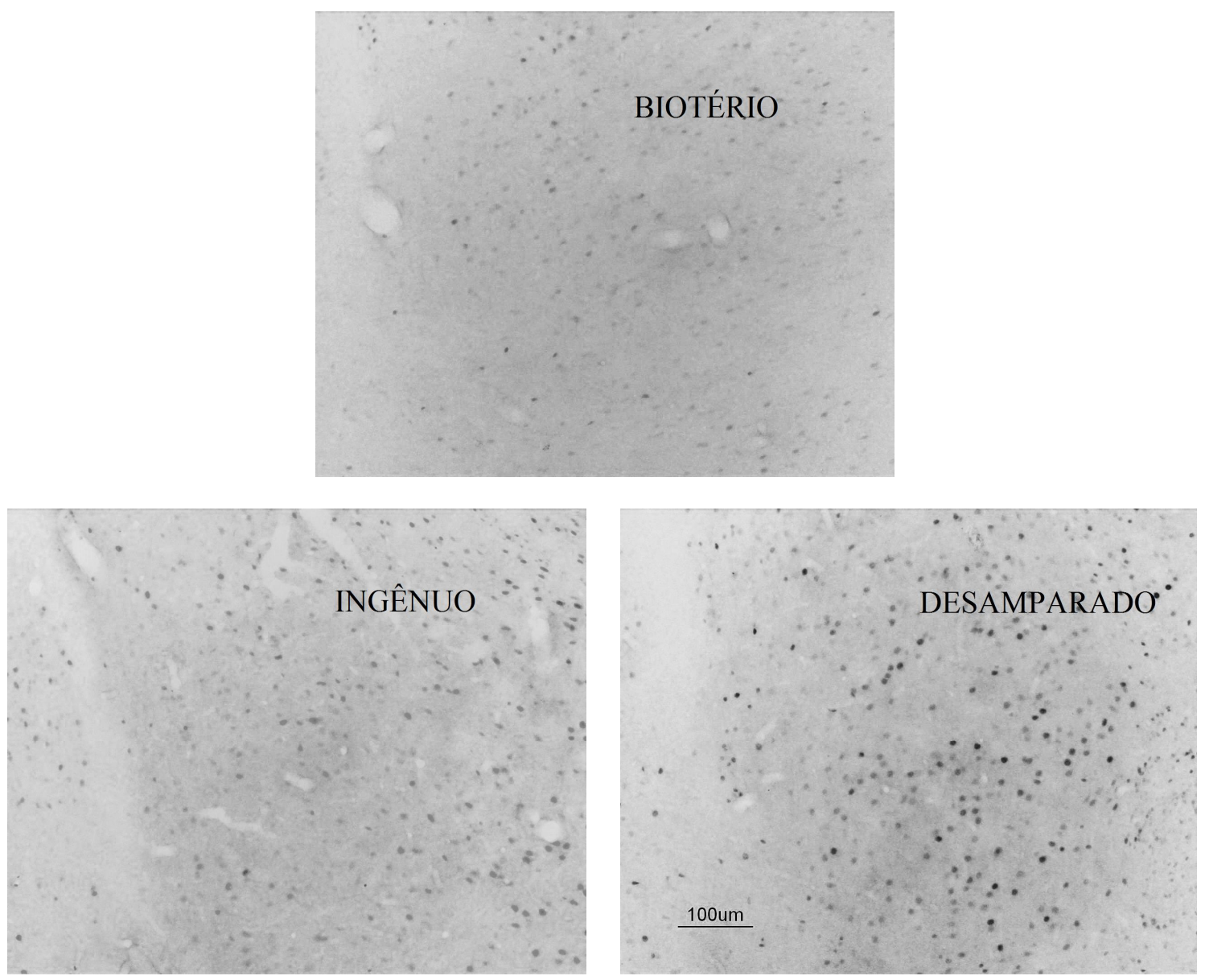

Figura 9 - Imagens digitais de secções de encéfalo que ilustram a densidade de marcação para Egr-1 encontrada na amígdala basolateral para os grupos Biotério, Ingênuo e Desamparado.

\subsubsection{Amígdala Central}

A descrição gráfica dos valores médios de densidade de núcleos imunorreativos para Fos e Egr-1 estimados na amígdala central (ACe) está disponível na Figura 10. Considerando a proteína Fos, o maior valor médio de densidade de núcleos imunorreativos foi encontrado no grupo ING e o menor valor médio estimado no grupo BIO. A ANOVA, entretanto, não indicou existirem diferenças significantes entre os grupos $\left(\mathrm{F}_{4,26}=1,792, \mathrm{p}=0,1608\right)$. No caso da proteína Egr-1, o grupo DES apresentou o 
maior valor médio e os grupos BIO e ING os menores valores. A ANOVA indicou a presença de diferença significante $\left(\mathrm{F}_{4,27}=3.108, \mathrm{p}=0,0317\right)$ que o teste de múltiplas comparações identificou ocorrer entre os grupos ING e DES $(p<0,05)$. Não foi encontrada diferença significante (gráfico menor) quando as densidades médias totais para Fos e Egr-1 na ACe foram comparadas $\left(\mathrm{t}_{30}=1,451, \mathrm{p}=0,1573\right)$.
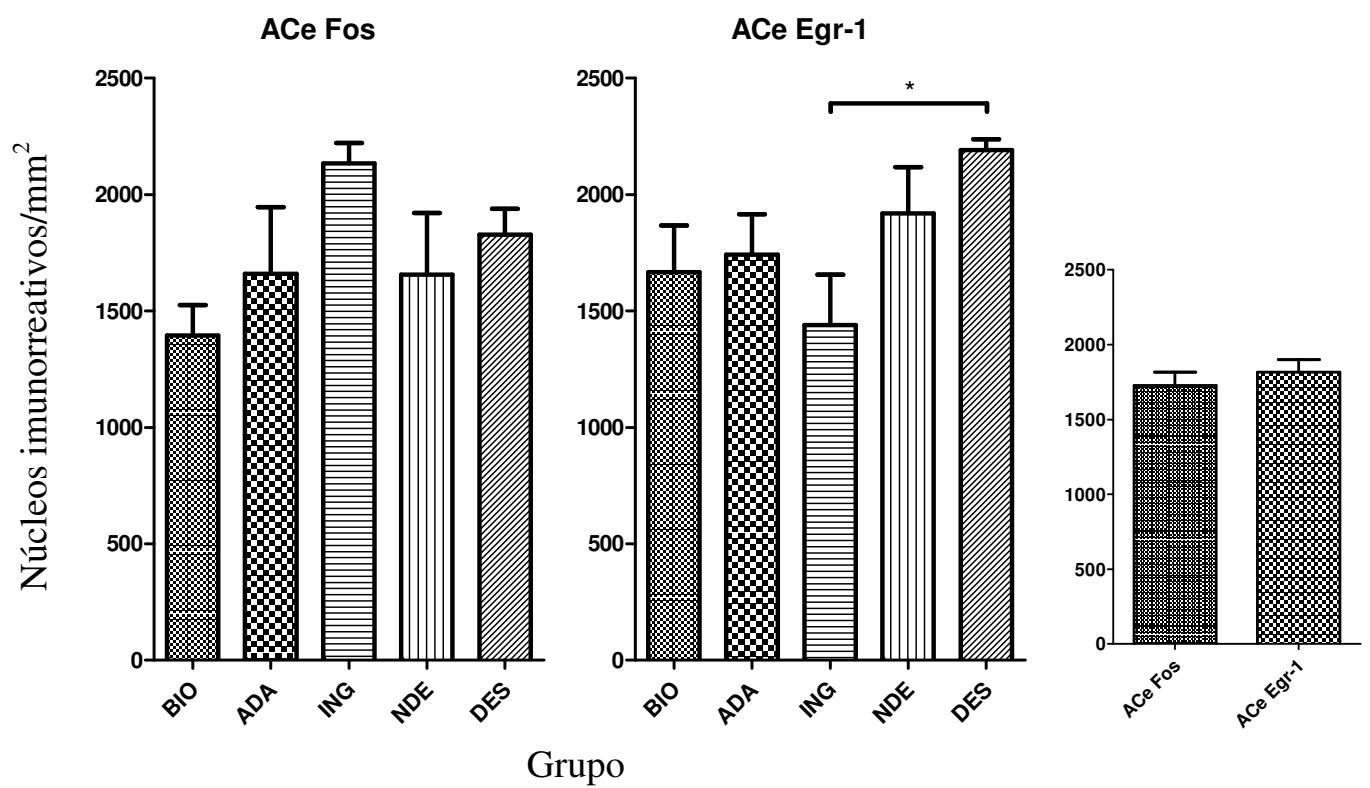

Figura 10 - Valores médios ( \pm epm) de densidade de núcleos imunorreativos para Fos e Egr-1 na amígdala central (ACe) dos grupos Biotério (BIO), Adaptação (ADA), Ingênuo (ING), Não Desamparado (NDE) e Desamparado (DES), e as médias totais dos marcadores para a estrutura. A análise estatística mostrou diferença significante somente na imunorreatividade para Egr-1 entre os grupos ING e DES $(* p<0,05)$.

\subsubsection{Córtex Pré-frontal Medial}

Na Figura 11 são apresentados os valores médios das densidades de núcleos imunorreativos para Fos e Egr-1 estimados no córtex pré-frontal medial (CPFm). A ANOVA indicou existirem diferenças significativas entre os valores dos grupos para Fos $\left(\mathrm{F}_{4,27}=13,73, \mathrm{p}<0,0001\right)$ e a comparação múltipla evidenciou diferenças significantes 
entre o grupo ING e os valores de todos os demais grupos (para todos, $p<0,001$ ). Não foram encontradas diferenças significantes entre os valores médios dos grupos para Egr$1\left(\mathrm{~F}_{4,27}=1,866, \mathrm{p}=0,1454\right)$, porém a diferença entre os valores de densidade média total de núcleos imunorreativos para Fos e Egr-1 (gráfico menor) na estrutura foi significante $\left(\mathrm{t}_{31}=13,07, \mathrm{p}<0,0001\right)$.
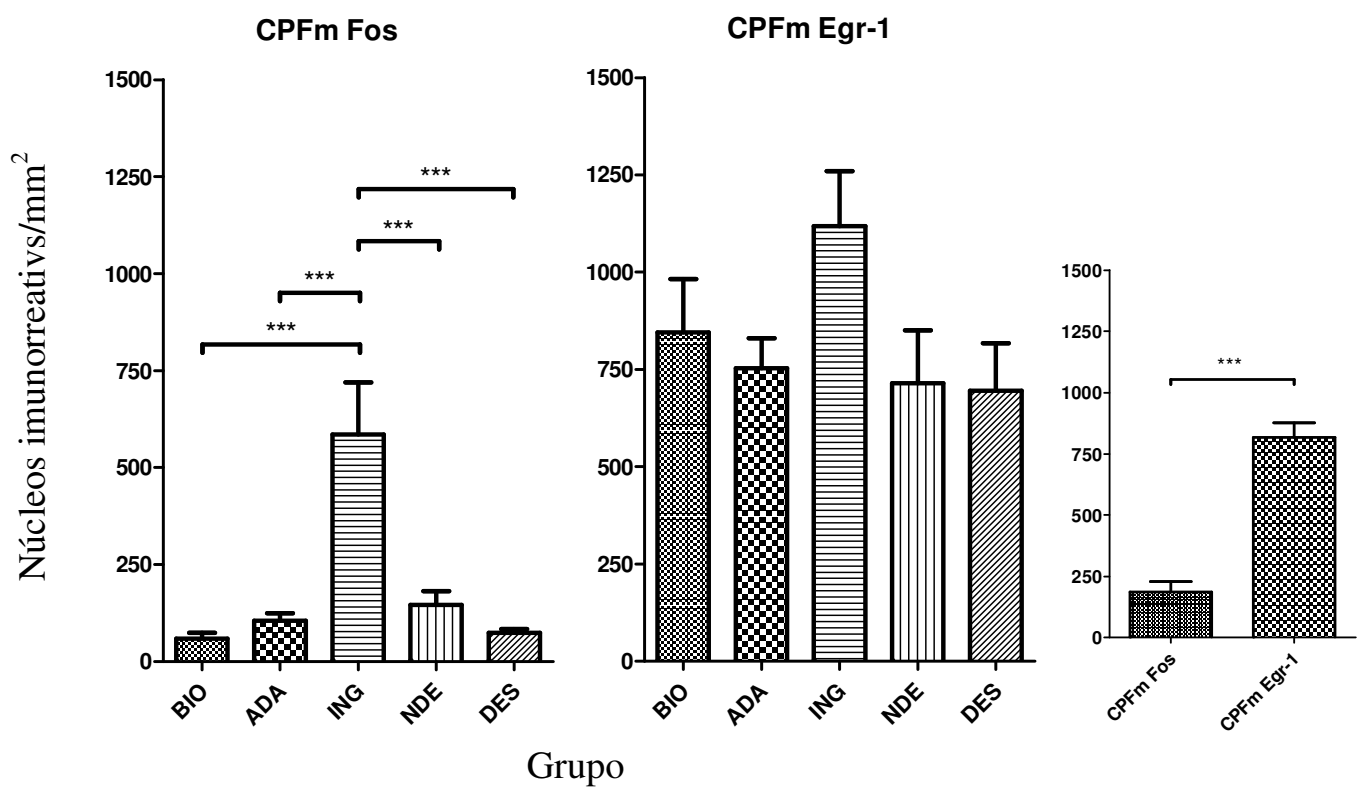

Figura 11 - Valores médios ( \pm epm) de densidade de núcleos imunorreativos para Fos e Egr-1 no córtex pré-frontal medial (CPFm) dos grupos Biotério (BIO), Adaptação (ADA), Ingênuo (ING), Não Desamparado (NDE) e Desamparado (DES), e as médias totais dos marcadores para a estrutura. A análise estatística mostrou diferenças significantes para Fos entre os grupos e entre as médias totais dos marcadores $(* * * \mathrm{p}<$ $0,001)$.

\subsubsection{Hipocampo, área Cornus Ammonis 1}

A Figura 12 apresenta os valores médios de densidade de núcleos imunorreativos para Fos e Egr-1 estimados no hipocampo, área Cornus Ammonis 1 (CA1). Observa-se que o maior valor para Fos ocorreu no grupo ING. A ANOVA indicou a presença de 
diferenças entre as médias dos grupos para este marcador $\left(\mathrm{F}_{4,27}=12,92, \mathrm{p}<0,0001\right)$ e a comparação múltipla evidenciou que a média do grupo ING diferiu de todas as demais médias (BIO, $\mathrm{p}<0,001$; ADA, $\mathrm{p}<0,01$; NDE, $\mathrm{p}<0,001$; DES, $\mathrm{p}<0,001$ ). As médias de imunorreatividade para Egr-1 na área CA1 não apresentaram diferenças significantes entre os grupos $\left(\mathrm{F}_{4,27}=1,407, \mathrm{p}=0,2585\right)$, porém a diferença entre o total de núcleos marcados para Fos e Egr-1 (gráfico menor) foi significante $\left(\mathrm{t}_{31}=26,86, \mathrm{p}<0,0001\right)$.
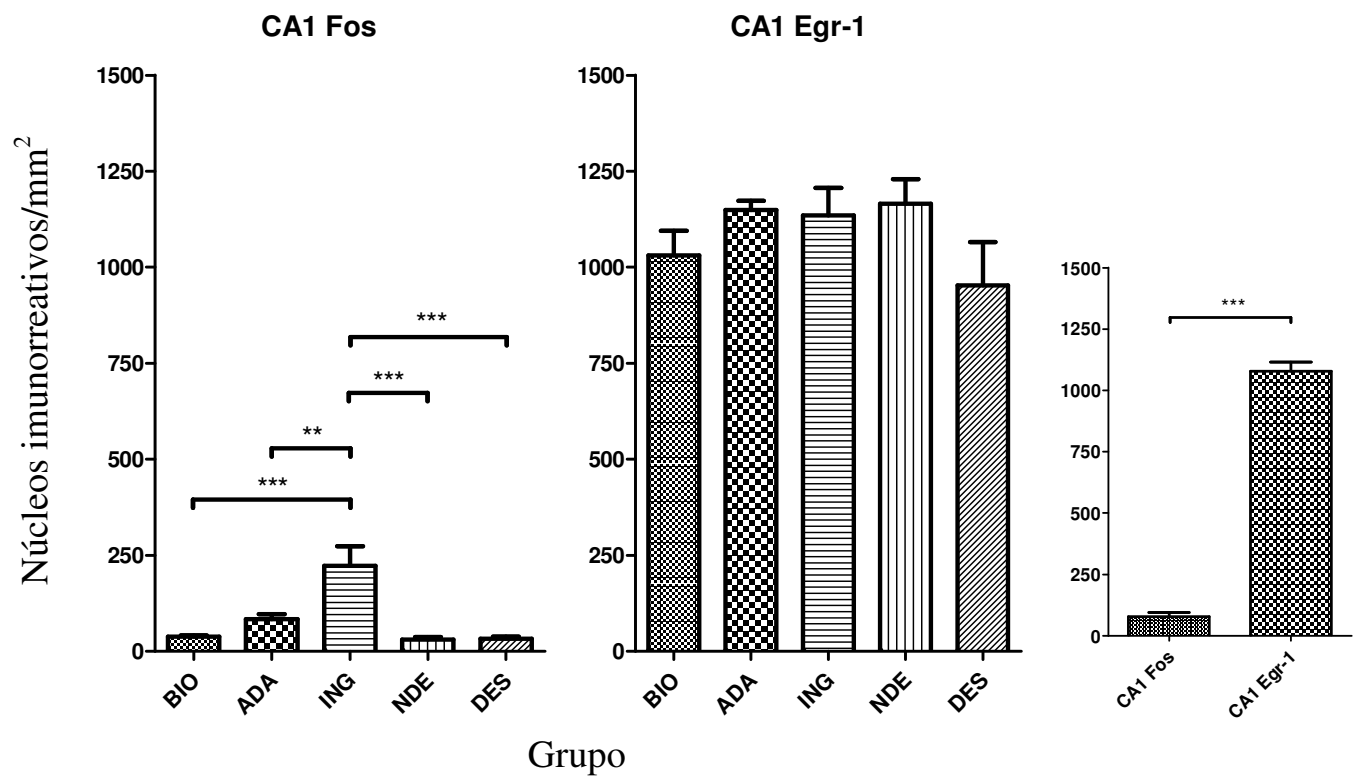

Figura 12 - Valores médios ( \pm epm) de densidade de núcleos imunorreativos para Fos e Egr-1 no hipocampo, área Cornus Ammonis 1 (CA1) dos grupos Biotério (BIO), Adaptação (ADA), Ingênuo (ING), Não Desamparado (NDE) e Desamparado (DES) e as médias totais dos marcadores para a estrutura. A análise estatística mostrou diferenças significantes na imunorreatividade para Fos entre os grupos e entre as médias totais dos marcadores $(* * \mathrm{p}<0,01, * * * \mathrm{p}<0,001)$.

\subsubsection{Hipocampo, área Cornus Ammonis 3}

Os valores médios de densidade de núcleos imunorreativos para Fos e Egr-1 estimados no hipocampo, área Cornus Ammonis 3 (CA3) são apresentados na Figura 13. 
A ANOVA indicou não existirem diferenças significantes entre os grupos com relação ao marcador Fos $\left(\mathrm{F}_{4,27}=2,321, \mathrm{p}=0,0825\right)$. $\mathrm{O}$ mesmo teste, quando realizado para Egr1, também não encontrou diferenças que fossem relevantes entre os grupos $\left(\mathrm{F}_{4,27}=\right.$ 0,2796, $\mathrm{p}=0,8886)$. No caso da análise das densidades médias totais de núcleos imunorreativos para Fos e para Egr-1 (gráfico menor) foi encontrada uma pequena diferença significante $\left(t_{31}=2,334, p=0,0262\right)$.

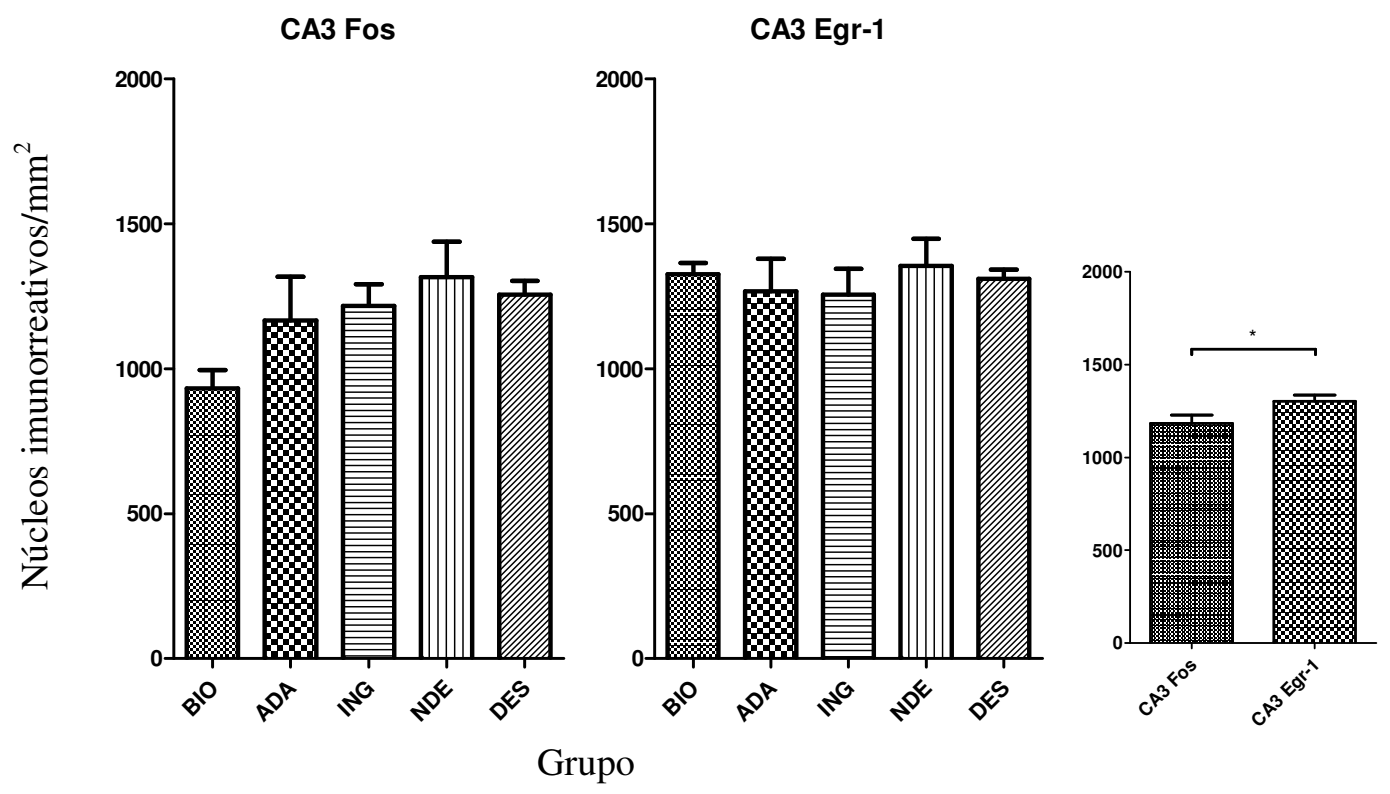

Figura 13 - Valores médios ( \pm epm) de densidade de núcleos imunorreativos para Fos e Egr-1 no hipocampo, área Cornus Ammonis 3 (CA3) dos grupos Biotério (BIO), Adaptação (ADA), Ingênuo (ING), Não Desamparado (NDE) e Desamparado (DES), e as médias totais dos marcadores nessa estrutura. A análise estatística evidenciou diferença significante somente entre as médias totais dos marcadores $(* \mathrm{p}<0,05)$.

\subsubsection{Hipocampo, área do Giro Denteado}

Na Figura 14 estão disponíveis os gráficos com os valores médios de densidade de núcleos imunorreativos para Fos e Egr-1 estimados no hipocampo, na área do giro denteado (GD). No caso da imunorreatividade para Fos, os valores encontrados para os 
diferentes grupos experimentais foram bastante semelhantes, não apresentando diferenças que pudessem ser consideradas significantes $\left(F_{4,27}=0,8358, p=0,5144\right)$. A ANOVA dos valores médios de imunorreatividade para Egr-1, por sua vez, indicou existirem diferenças significantes entre os grupos $\left(F_{4,27}=7,995, p=0,0002\right)$. A comparação múltipla revelou que o grupo DES, que apresentou o maior valor médio de imunorreatividade, diferiu estatisticamente dos grupos BIO $(p<0,001)$, ADA $(p<0,01)$ e NDE $(\mathrm{p}<0,05)$. A exceção refere-se ao valor médio do grupo ING, cuja diferença com o grupo DES não foi significante. $\mathrm{O}$ mesmo não ocorreu com a diferença entre as densidades médias totais de núcleos imunorreativos para Fos e para Egr-1 (gráfico menor), que foi significante $\left(\mathrm{t}_{31}=4,938, \mathrm{p}<0,0001\right)$.
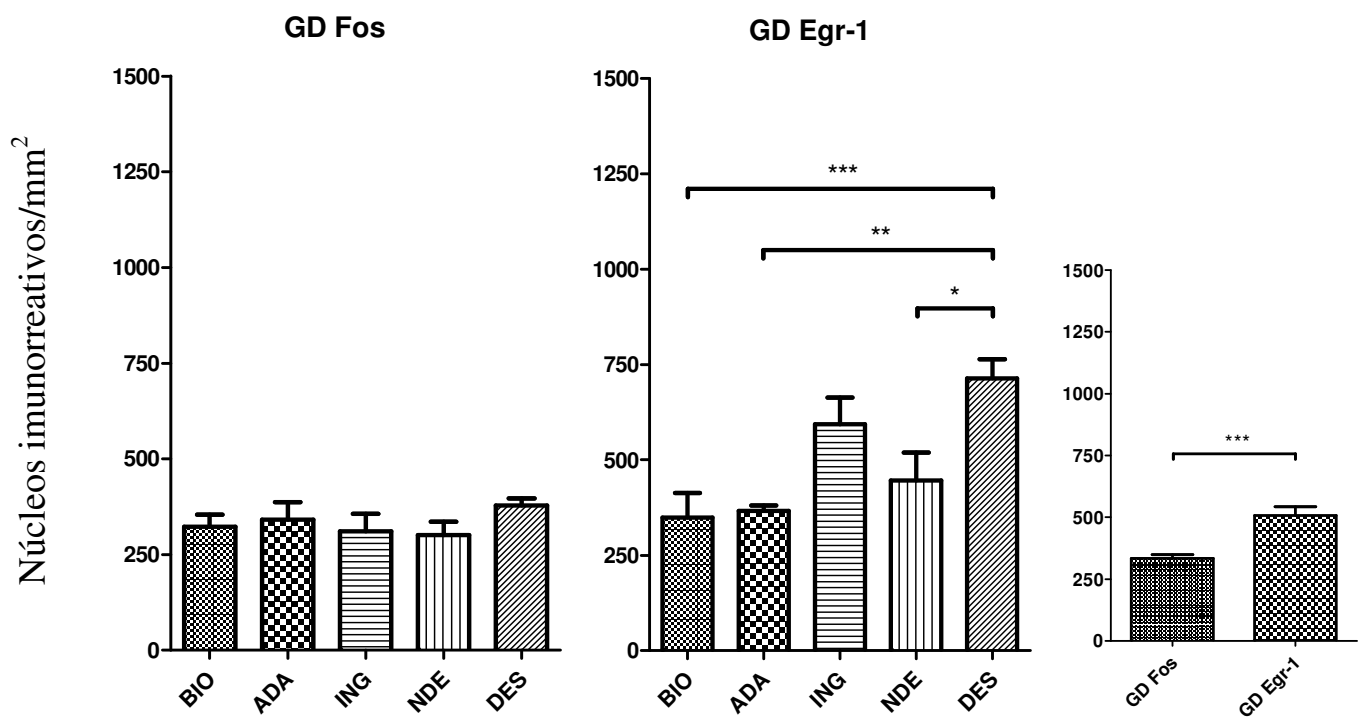

Grupo

Figura 14 - Valores médios ( \pm epm) de densidade de núcleos imunorreativos para Fos e Egr-1 no hipocampo, área do giro denteado (GD) dos grupos Biotério (BIO), Adaptação (ADA), Ingênuo (ING), Não Desamparado (NDE) e Desamparado (DES), e as médias totais dos marcadores para essa estrutura. A análise estatística evidenciou diferenças significantes na imunorreatividade para Egr-1 entre os grupos e entre as médias totais dos marcadores $\left(* \mathrm{p}<0,05,{ }^{* *} \mathrm{p}<0,01, * * * \mathrm{p}<0,001\right)$. 
As diferenças entre os grupos na densidade de marcação para Egr-1 no GD do HIP podem ser observadas nas imagens digitais da Figura 15. Observa-se nas imagens que os grupos $\mathrm{BIO}, \mathrm{ADA}$ e NDE apresentaram menor densidade de núcleos marcados quando comparados ao grupo DES.
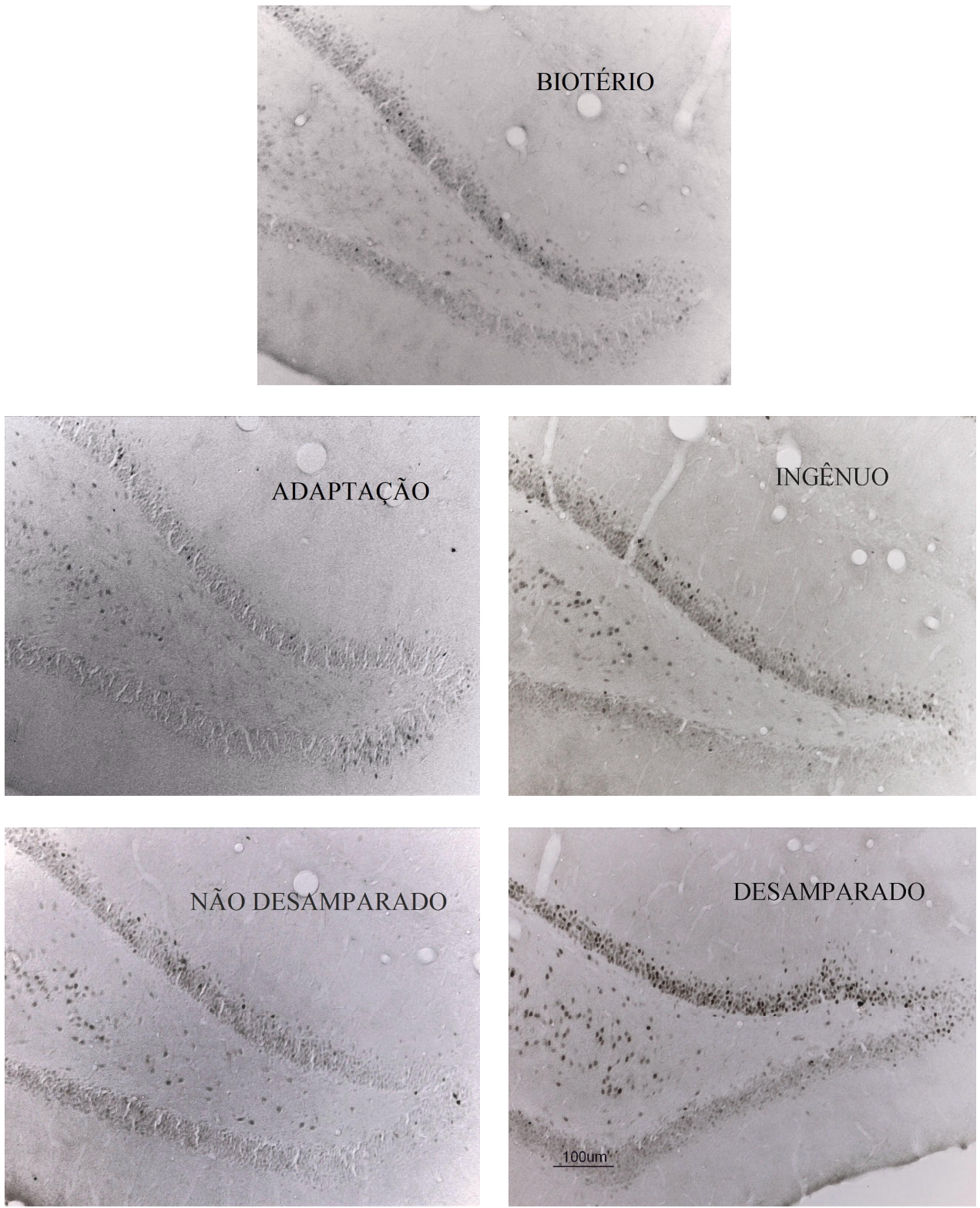

Figura 15 - Imagens digitais das secções de encéfalo que ilustram a densidade de marcação para Egr-1 observada no hipocampo, área do giro denteado, para os cinco grupos estudados no experimento. 


\subsubsection{Núcleo Septal Lateral}

Na Figura 16 são apresentados os resultados de imunorreatividade para Fos e Egr-1 no núcleo septal lateral (NSL). Embora seja possível observar diferenças entre as médias de densidade de núcleos imunorreativos para Fos estimados para os grupos nessa região, essas diferenças não se mostraram significantes quando realizada a análise de variância $\left(\mathrm{F}_{4,27}=2,385, \mathrm{p}=0,0761\right)$, o mesmo ocorrendo com relação aos valores médios de densidade de núcleos imunorreativos para Egr-1 entre os grupos $\left(\mathrm{F}_{4,27}=\right.$ 1,344, $\mathrm{p}=0$,2794). Já a diferença entre a densidade total de núcleos marcados para Fos em comparação com Egr-1 no NSL (gráfico menor) foi significante $\left(\mathrm{t}_{31}=7,182\right.$, $\mathrm{p}<$ $0,0001)$.
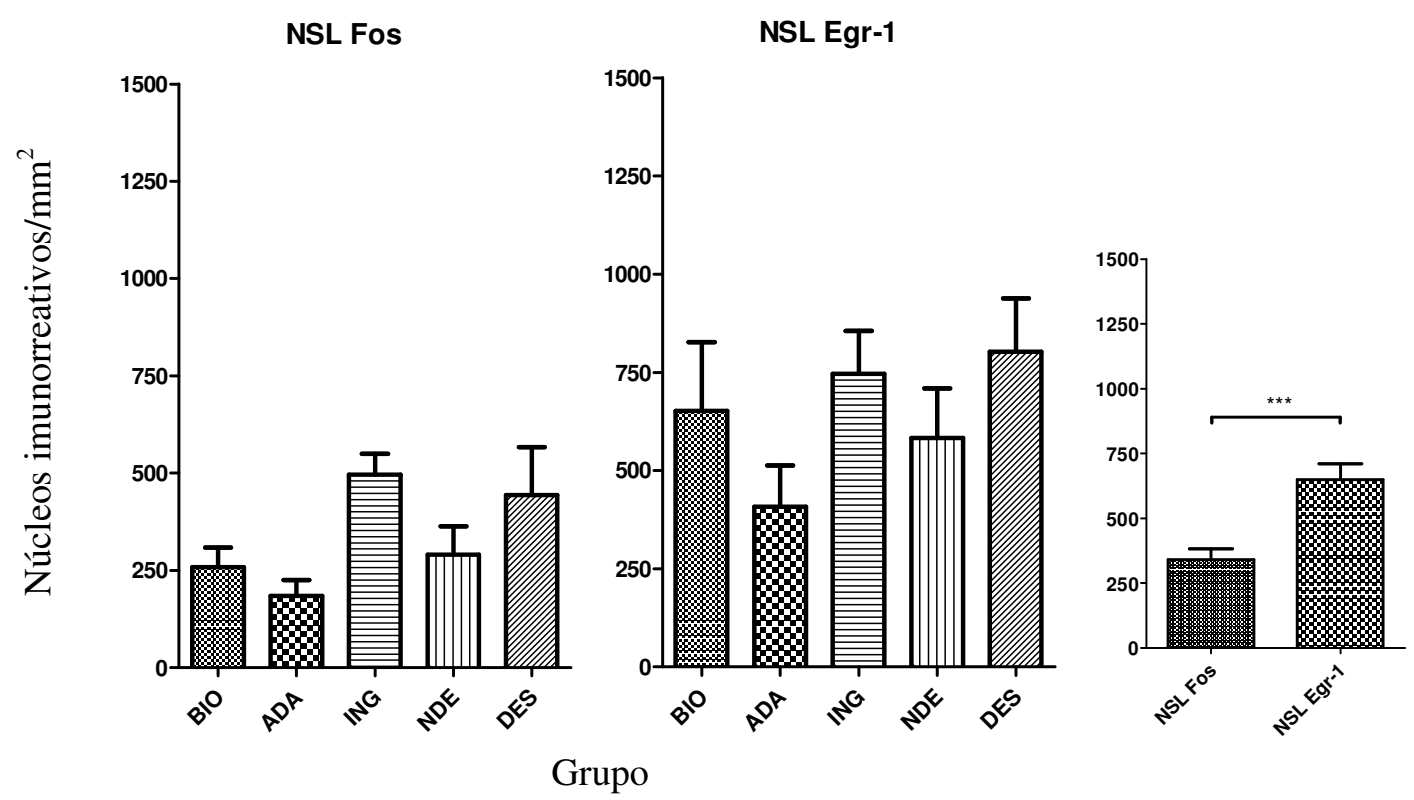

Figura 16 - Valores médios ( \pm epm) de densidade de núcleos imunorreativos para Fos e Egr-1 no núcleo septal lateral (NSL) dos grupos Biotério (BIO), Adaptação (ADA), Ingênuo (ING), Não Desamparado (NDE) e Desamparado (DES), e as médias totais dos marcadores para essa estrutura. A análise estatística mostrou diferença significante somente entre as médias totais dos marcadores $(* * * \mathrm{p}<0,001)$. 


\subsubsection{Análise Restrita aos Grupos BIO, ADA, NDE e DES}

Os sujeitos do grupo ING foram expostos a estímulo novo quando submetidos a choque no teste de fuga e, por esta razão, novas análises dos dados experimentais foram realizadas, desta vez excluindo esse grupo. A ANOVA seguida de comparação múltipla dos dados dos grupos BIO, ADA, NDE e DES mostraram existirem diferenças significantes entre os grupos. Foram significantes as diferenças na $A B L\left(F_{3,22}=2,986, p\right.$ $=0,0532)$ entre BIO e DES para Egr-1 $(p<0,05)$, no CPFm $\left(F_{3,22}=3,473, p=0,0333\right)$ entre BIO e NDE para Fos $(\mathrm{p}<0,05)$, no CA1 $\left(\mathrm{F}_{3,22}=10,24, \mathrm{p}=0,0002\right)$ entre BIO e ADA $(\mathrm{p}<0,01)$, ADA e NDE $(\mathrm{p}<0,001)$ e ADA e DES $(\mathrm{p}<0,001)$ para Fos, e no GD $\left(\mathrm{F}_{3,22}=10,70, \mathrm{p}=0,0002\right)$ entre BIO e DES $(\mathrm{p}<0,001)$, ADA e DES $(\mathrm{p}<0,001)$ e NDE e DES ( $\mathrm{p}<0,01)$ para Egr-1. Esses resultados estão descritos graficamente na Figura 17. 


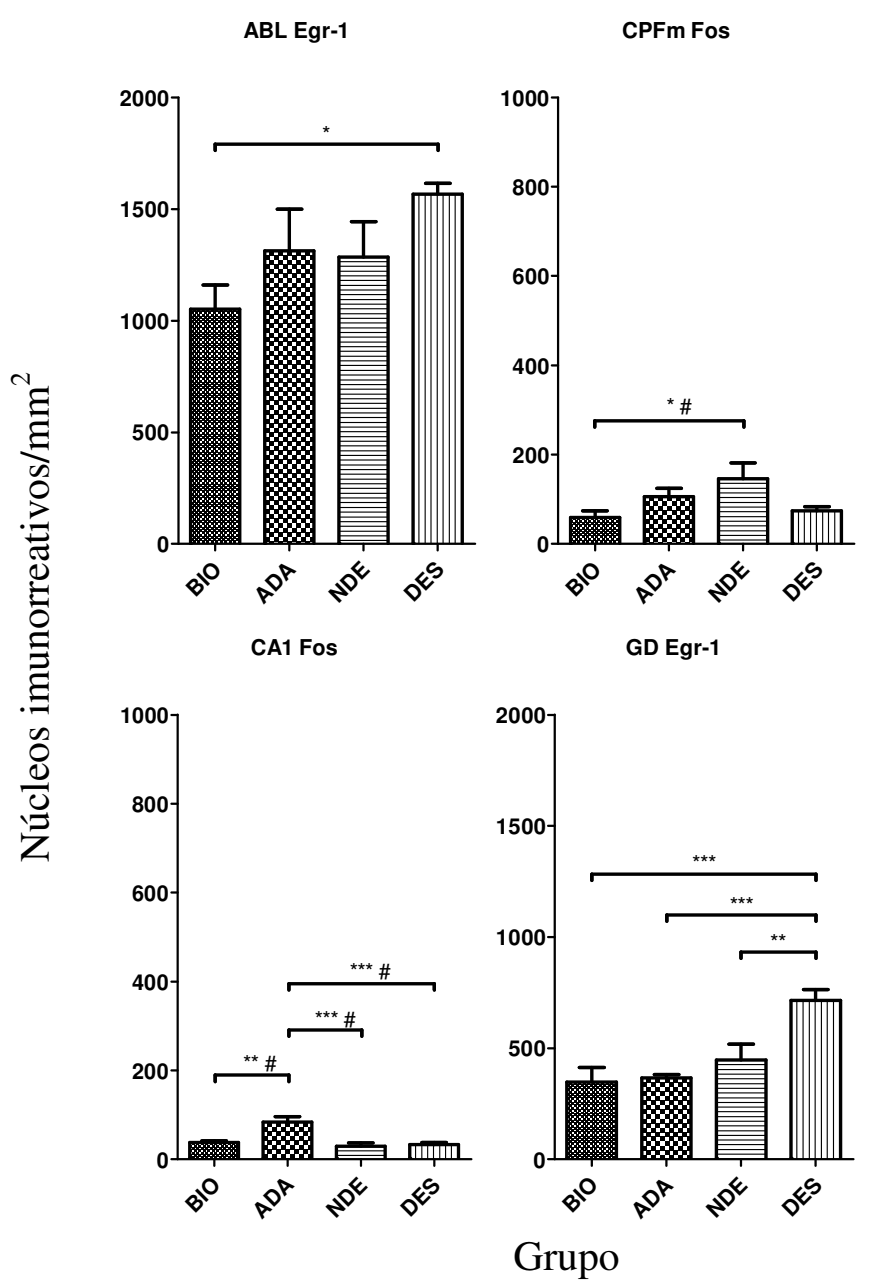

Figura 17 - Valores médios $( \pm$ epm) de densidade de núcleos imunorreativos para Fos ou Egr-1 na ABL, CPFm, CA1 e GD dos grupos Biotério (BIO), Adaptação (ADA), Não Desamparado (NDE) e Desamparado (DES). A análise estatística evidenciou diferenças significantes na imunorreatividade para Fos ou para Egr-1 entre os grupos $(* p<0,05$, $* * \mathrm{p}<0,01, * * * \mathrm{p}<0,001, \#$ novo dado significante).

\subsubsection{Análise Restrita aos Grupos ING, NDE e DES}

Os grupos ING, NDE e DES também foram analisados separadamente por serem os grupos típicos do modelo do desamparo aprendido, apresentando em comum o fato de terem sido submetidos ao teste de fuga na shuttlebox. Os gráficos da Figura 18 ilustram as diferenças significantes encontradas nessa análise. 


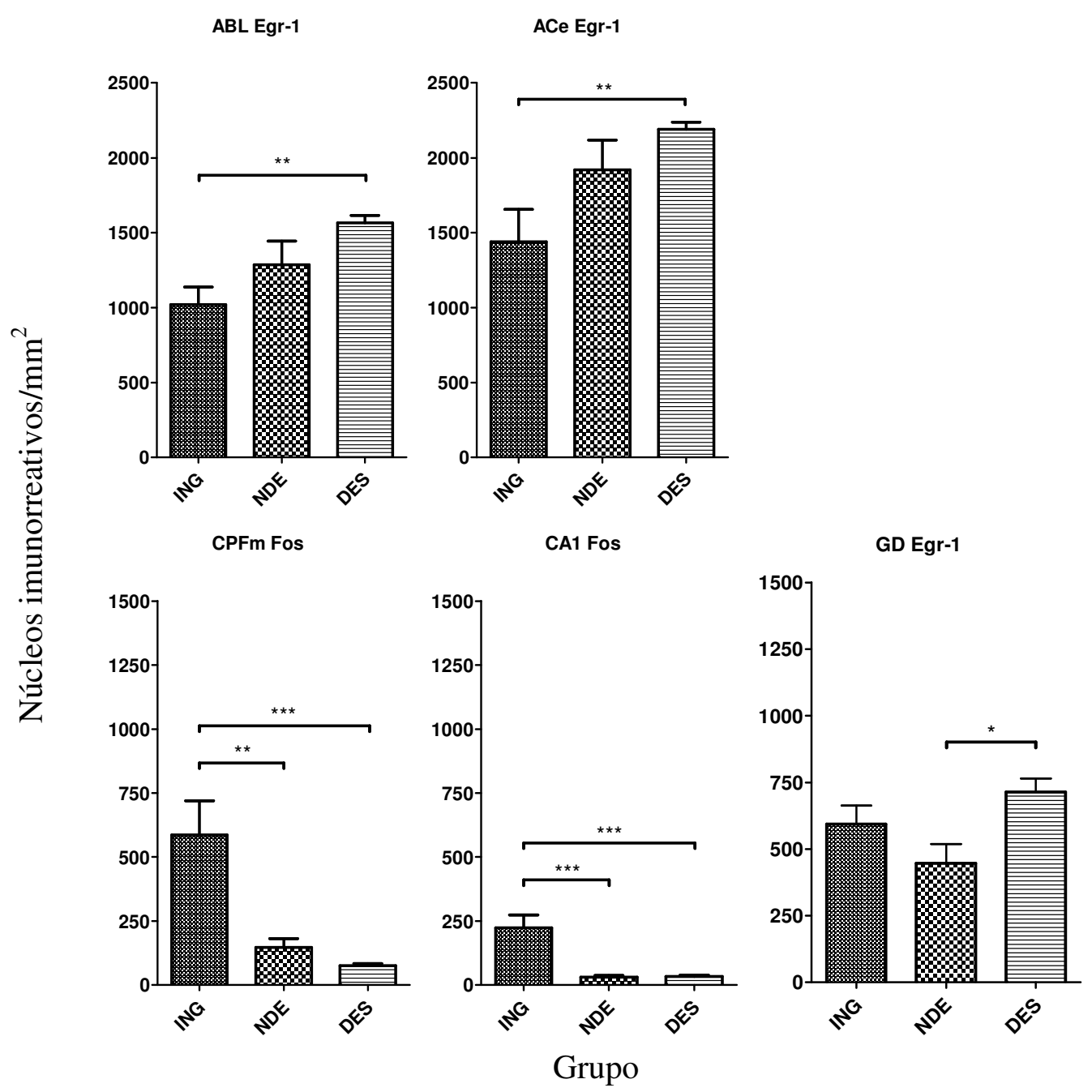

Figura 18 - Valores médios ( \pm epm) de densidade de núcleos imunorreativos para Fos ou Egr-1 na ABL, ACe, CPFm, CA1 e GD dos grupos Ingênuo (ING), Não Desamparado (NDE) e Desamparado (DES). A análise estatística evidenciou diferenças significantes na imunorreatividade para Fos ou para Egr-1 entre os grupos $\left({ }^{*} p<0,05\right.$, $* * \mathrm{p}<0,01, * * * \mathrm{p}<0,001)$.

Entre os grupos ING, NDE e DES, a ANOVA seguida de comparação múltipla evidenciou diferenças significantes entre os grupos na ABL $\left(F_{2,17}=6,777, p=0,0069\right)$ entre ING e DES $(\mathrm{p}<0,01)$ para Egr-1, na ACe $\left(\mathrm{F}_{2,17}=6,128, \mathrm{p}=0,01907\right)$ entre ING e DES $(p<0,01)$ também para Egr-1, no CPFm $\left(F_{2,17}=14,61, p=0,0002\right)$ entre ING e $\operatorname{NDE}(\mathrm{p}<0,01)$ e ING e DES $(\mathrm{p}<0,001)$ para Fos, no CA1 $\left(\mathrm{F}_{2,17}=16,04, \mathrm{p}=0,0001\right)$ 
entre ING e NDE $(\mathrm{p}<0,001)$ e ING e DES $(\mathrm{p}<0,001)$ também para Fos, e no GD $\left(\mathrm{F}_{2,17}\right.$ $=4,728, \mathrm{p}=0,0233)$ entre NDE e DES $(\mathrm{p}<0,05)$ para Egr-1.

Na Figura 19 imagens digitais ilustram a densidade de marcação para Egr-1 encontrada na ACe para os grupos ING e DES. Observa-se que a densidade de núcleos imunorreativos é maior na imagem que representa o grupo DES.
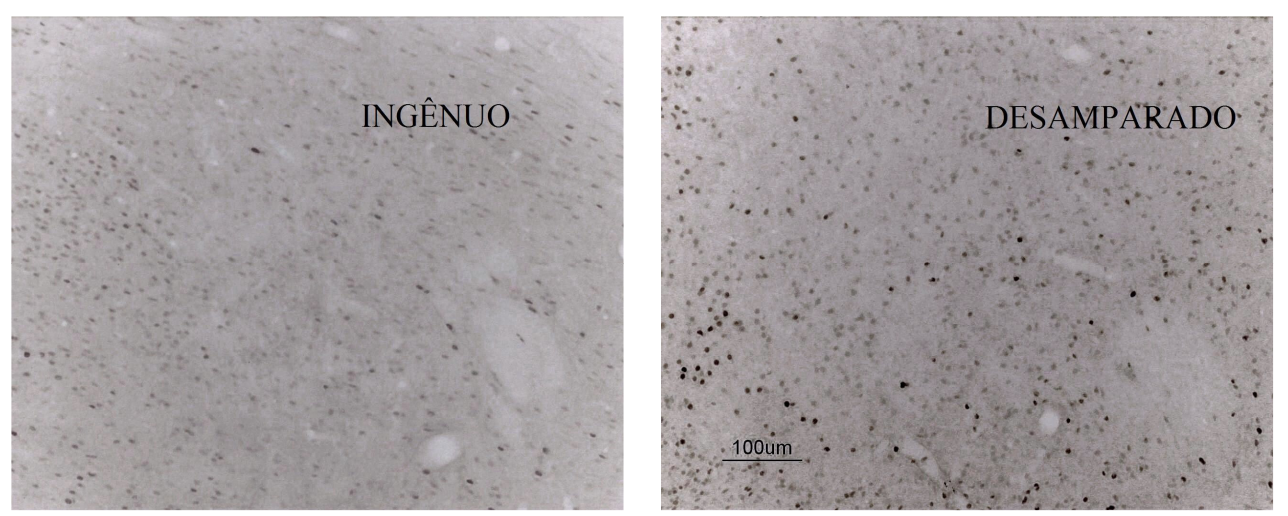

Figura 19 - Imagens digitais das secções de encéfalo que ilustram a densidade de marcação para Egr-1 observada na ACe para os grupos Ingênuo e Desamparado, cujas médias apresentaram diferença significante.

\subsubsection{Análise Restrita aos Grupos NDE e DES}

A Figura 20 mostra os resultados significantes obtidos na comparação das densidades médias de núcleos imunorreativos dos grupos NDE e DES nas diversas estruturas. Os grupos NDE e DES apresentam em comum o fato de terem sido expostos a duas sessões de choque, no tratamento e no teste de fuga. A comparação das duas condições, realizada por meio do teste $t$ de Student para amostras independentes mostrou existirem diferenças significantes entre as médias das densidades para Fos no CPFm $\left(\mathrm{t}_{12}\right.$ $=2,264, \mathrm{p}=0,0429)$ e no GD para Egr-1 $\left(\mathrm{t}_{12}=3,153, \mathrm{p}=0,0083\right)$. 

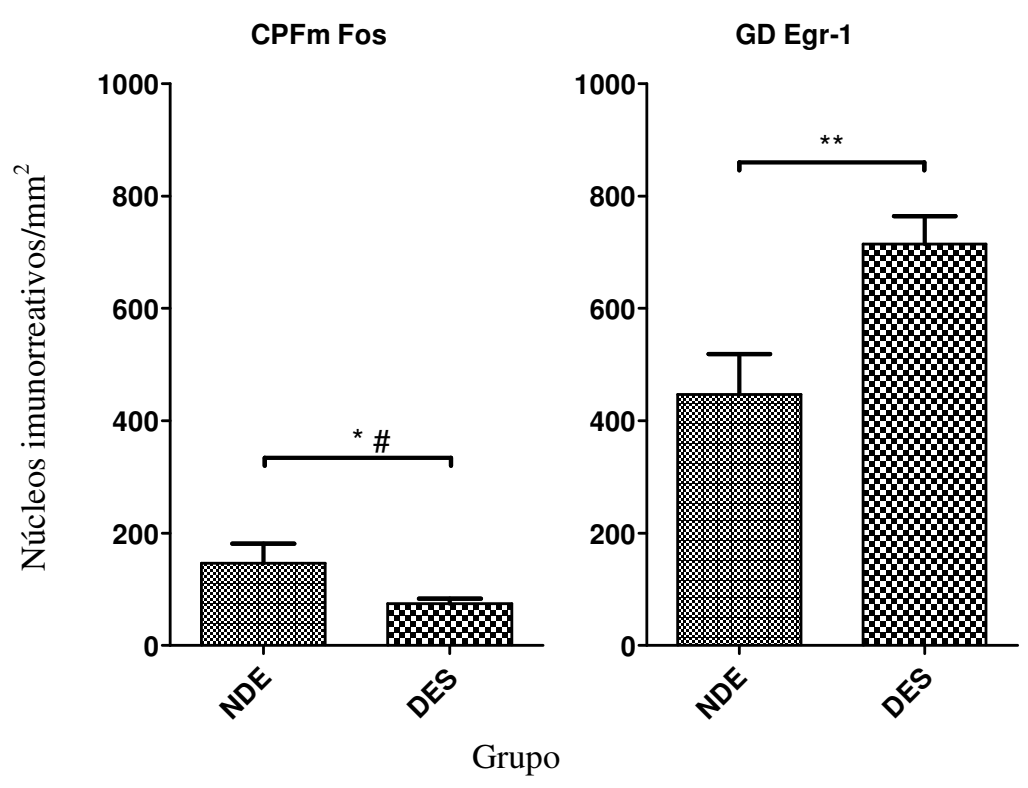

Figura 20 - Valores médios ( \pm epm) de densidade de núcleos imunorreativos para Fos e Egr-1 nas estruturas CPFm e GD, respectivamente, para os grupos NDE e DES. A análise estatística evidenciou diferenças significantes na imunorreatividade para Fos no CPFm, e para Egr-1 no GD (*p $<0,05, * * p<0,01$, \# novo dado significante).

Na Figura 21 estão disponíveis as imagens digitais que ilustram a densidade de marcação para Fos no CPFm dos grupos NDE e DES. Observa-se que a densidade de núcleos imunorreativos é menor na imagem que representa o grupo DES.
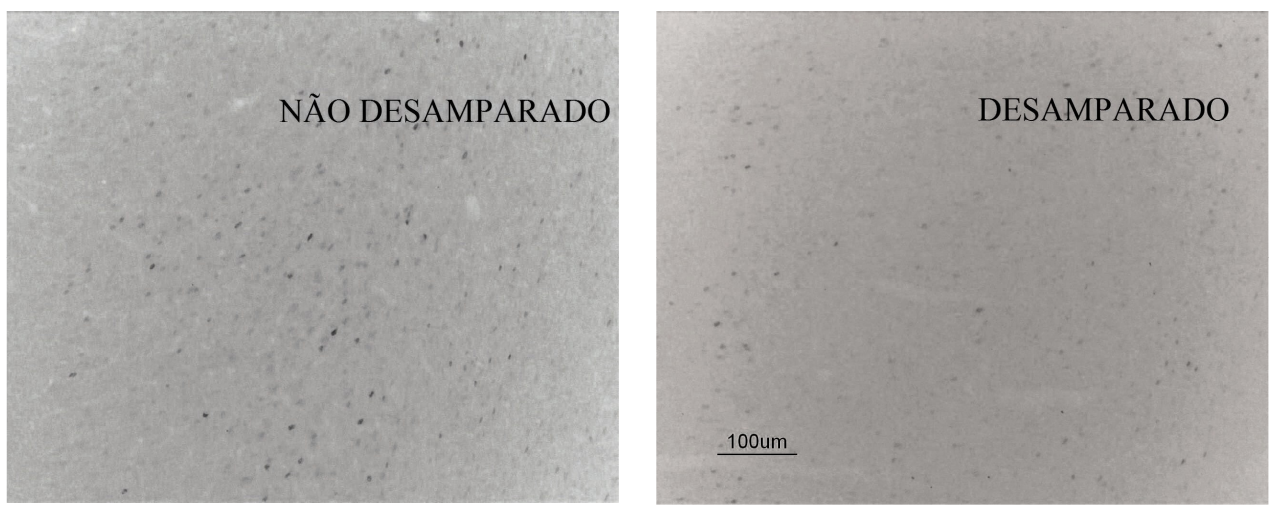

Figura 21 - Imagens digitais das secções de encéfalo que ilustram a diferença na densidade de marcação para Fos observada no CPFm entre os grupos NDE e DES, cujas médias apresentaram diferença significante. 


\subsubsection{Análise Restrita aos Grupos BIO e ADA}

A comparação das densidades médias de núcleos imunorreativos entre os grupos $\mathrm{BIO}$ e ADA, que não foram expostos a choque, mostrou haver diferença significante na imunorreatividade para Fos na área CA1 do hipocampo $\left(\mathrm{t}_{10}=3,457, \mathrm{p}=0,0062\right)$. Não foi encontrada diferença significante entre as densidades médias para Egr-1 dos dois grupos.

\subsubsection{Análise Restrita ao Grupo BIO - Expressão Basal}

Herdegen e Leah (1998) definem que a 'expressão basal' é aquela causada por sinais exógenos ao organismo não estimulado intencionalmente. Conforme mencionado em Método, os sujeitos do grupo BIO não foram submetidos à adaptação, a tratamento ou a teste e, portanto, representam o grupo não estimulado intencionalmente neste estudo. A Figura 22 mostra os resultados da comparação das densidades médias de núcleos imunorreativos para Fos e Egr-1 do grupo BIO. Observa-se na figura que as médias de densidade de núcleos imunorreativos para Egr-1 foram sempre maiores que as médias para Fos. Foram significantes as diferenças encontradas nas estruturas ABL $\left(t_{5}=\right.$ $3,211, \mathrm{p}=0,0237), \mathrm{CPFm}\left(\mathrm{t}_{5}=5,753, \mathrm{p}=0,0022\right), \mathrm{CA} 1\left(\mathrm{t}_{5}=15,21, \mathrm{p}<0,0001\right), \mathrm{CA} 3$ $\left(t_{5}=11,43, p<0,0001\right)$ e NSL $\left(t_{5}=3,062, p=0,0280\right)$. Não foram significantes as diferenças encontradas nas estruturas ACe $\left(t_{5}=1,483, p=0,1983\right)$ e GD $\left(t_{5}=0,3714, p\right.$ $=0,7256)$. 


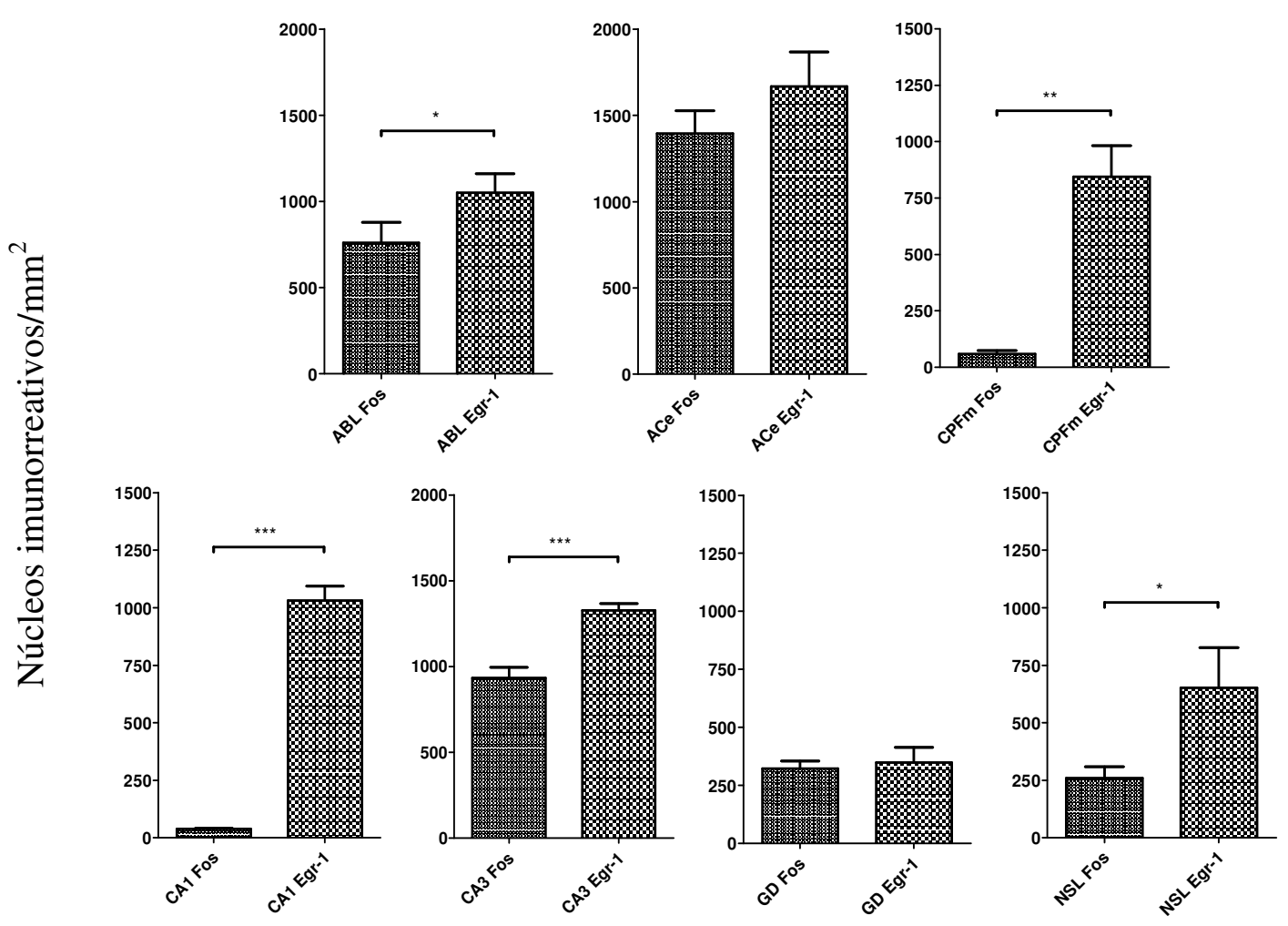

Grupo

Figura 22 - Valores médios ( \pm epm) de densidade de núcleos imunorreativos para Fos e Egr-1 nas estruturas estudadas para o grupo Biotério (BIO). A análise estatística evidenciou diferenças significantes na expressão basal dos marcadores Fos e Egr-1 nas estruturas $(* \mathrm{p}<0,05, * * \mathrm{p}<0,01, * * * \mathrm{p}<0,001)$.

\subsection{COVARIAÇÃO DOS DADOS DE IMUNORREATIVIDADE}

A covariação dos dados de imunorreatividade para Fos e Egr-1 foi avaliada por meio do cálculo do coeficiente de correlação (r) de Pearson. No Apêndice do trabalho estão disponíveis os coeficientes de correlação e os níveis de significância que resultaram dessa avaliação (Quadros II e III, respectivamente). Na Figura 23 são apresentados os diagramas de dispersão dos dados de imunorreatividade que resultaram em coeficientes de correlação significantes maiores que 0,6, e que foram as seguintes: 
ACe Fos e ABL Fos ( $r=0,9482, p<0,0001)$, ACe Egr-1 e ABL Egr-1 ( $r=0,9017, p<$ 0,0001), CA1 Fos e CPFm Fos $(r=0,7253, p<0,0001)$, NSL Fos e NSL Egr-1 ( $r=$ 0,7188, $\mathrm{p}<0,0001)$, NSL Fos e GD Egr-1 ( $\mathrm{r}=0,6801, \mathrm{p}<0,0001)$, NSL Egr-1 e GD Egr-1 $(r=0,6382, p<0,0001)$, e ABL Egr-1 e CA3 Egr-1 $(r=0,6170, p=0,0002)$
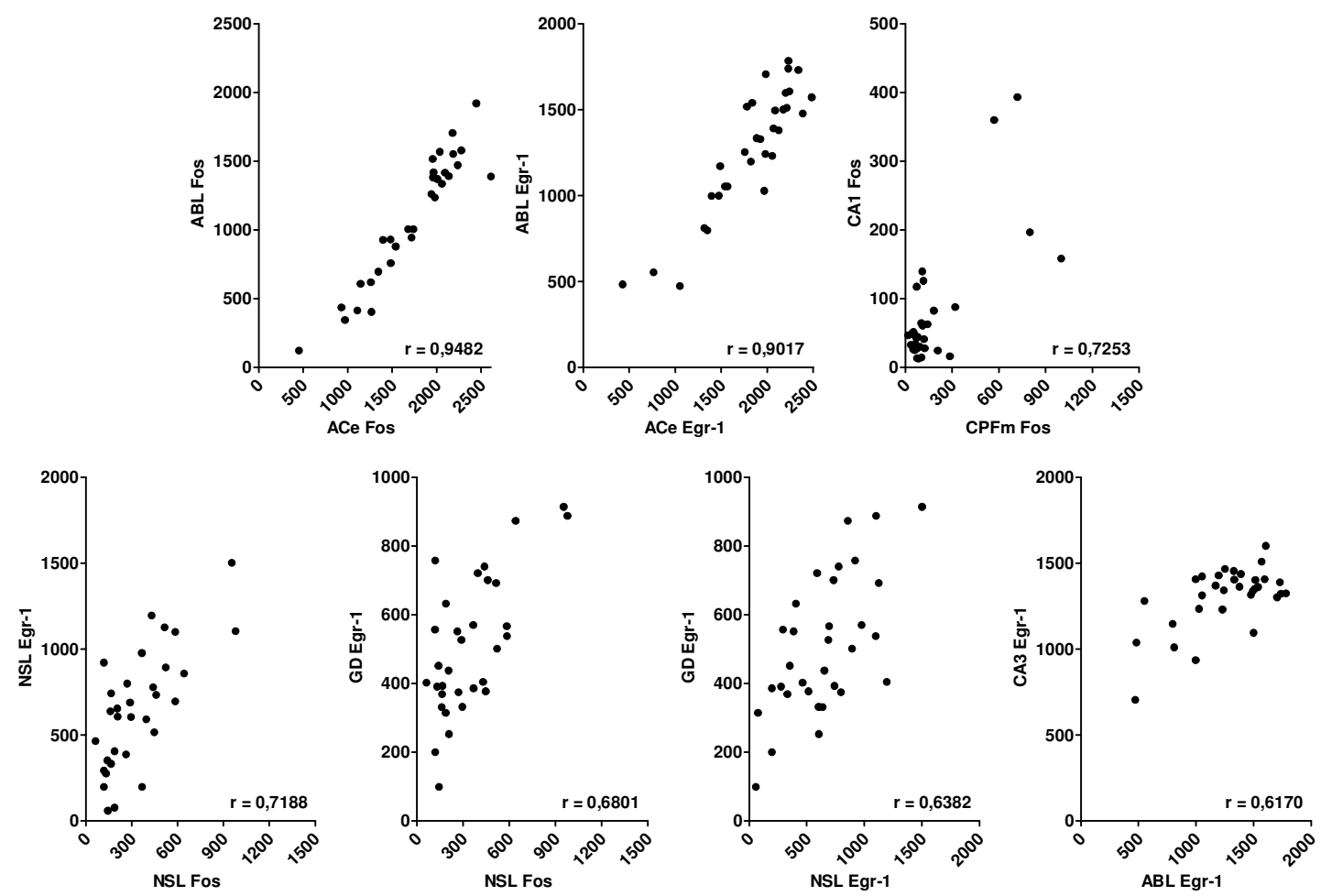

Figura 23 - Diagramas de dispersão dos dados de imunorreatividade das estruturas que resultaram em coeficientes de correlação de Pearson (r) significantes superiores a 0,6.

A Figura 24 apresenta os resultados da análise das densidades médias totais de núcleos imunorreativos para Fos e Egr-1 em cada um dos grupos. Observa-se na figura que os valores médios de densidade de núcleos imunorreativos para Fos foram menores do que os valores para Egr-1 nas cinco condições experimentais, com diferenças significantes em todas as comparações realizadas $\left(\mathrm{BIO}, \mathrm{t}_{41}=7,321, \mathrm{p}<0,0001\right.$; ADA, 
$\mathrm{t}_{41}=4,319, \mathrm{p}<0,0001 ; \mathrm{ING}, \mathrm{t}_{40}=2,532, \mathrm{p}=0,0154 ; \mathrm{NDE}, \mathrm{t}_{41}=5,863, \mathrm{p}<0,0001 ;$ DES, $\left.\mathrm{t}_{55}=8,595, \mathrm{p}<0,0001\right)$.
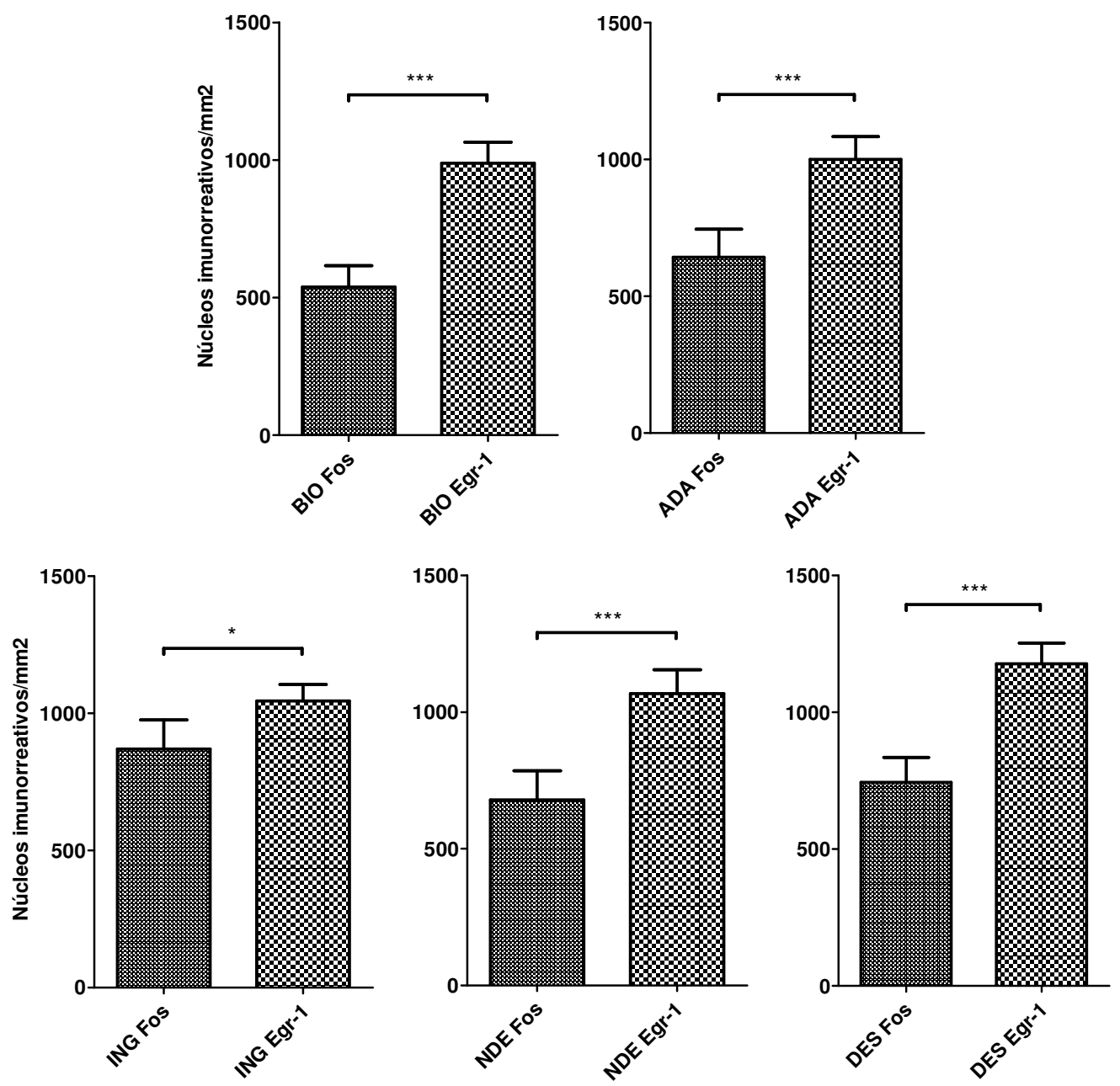

Figura 24 - Comparação dos valores médios ( \pm epm) de densidade de núcleos imunorreativos para Fos e Egr-1 nos cinco grupos experimentais. A análise estatística evidenciou diferenças significantes entre as médias para Fos e Egr-1 em todos os grupos $(* \mathrm{p}<0,05,(* * * \mathrm{p}<0,001)$

Na Figura 25 são apresentados os diagramas de dispersão dos dados de imunorreatividade para Fos e Egr-1 de cada grupo, para todos os grupos experimentais. A figura mostra coeficientes de correlação altos para todos os grupos. O menor coeficiente foi encontrado no grupo ADA $(r=0,6236, p<0,0001)$ e o maior no grupo 
DES $(r=0,8322, p<0,0001)$. Os grupos BIO, ING e NDE apresentaram valores intermediários $(\mathrm{BIO}, \mathrm{r}=0,6819, \mathrm{p}<0,0001$; ING, $\mathrm{r}=0,7210, \mathrm{p}<0,0001$; NDE, $\mathrm{r}=$ $0,7817, \mathrm{p}<0,0001)$.
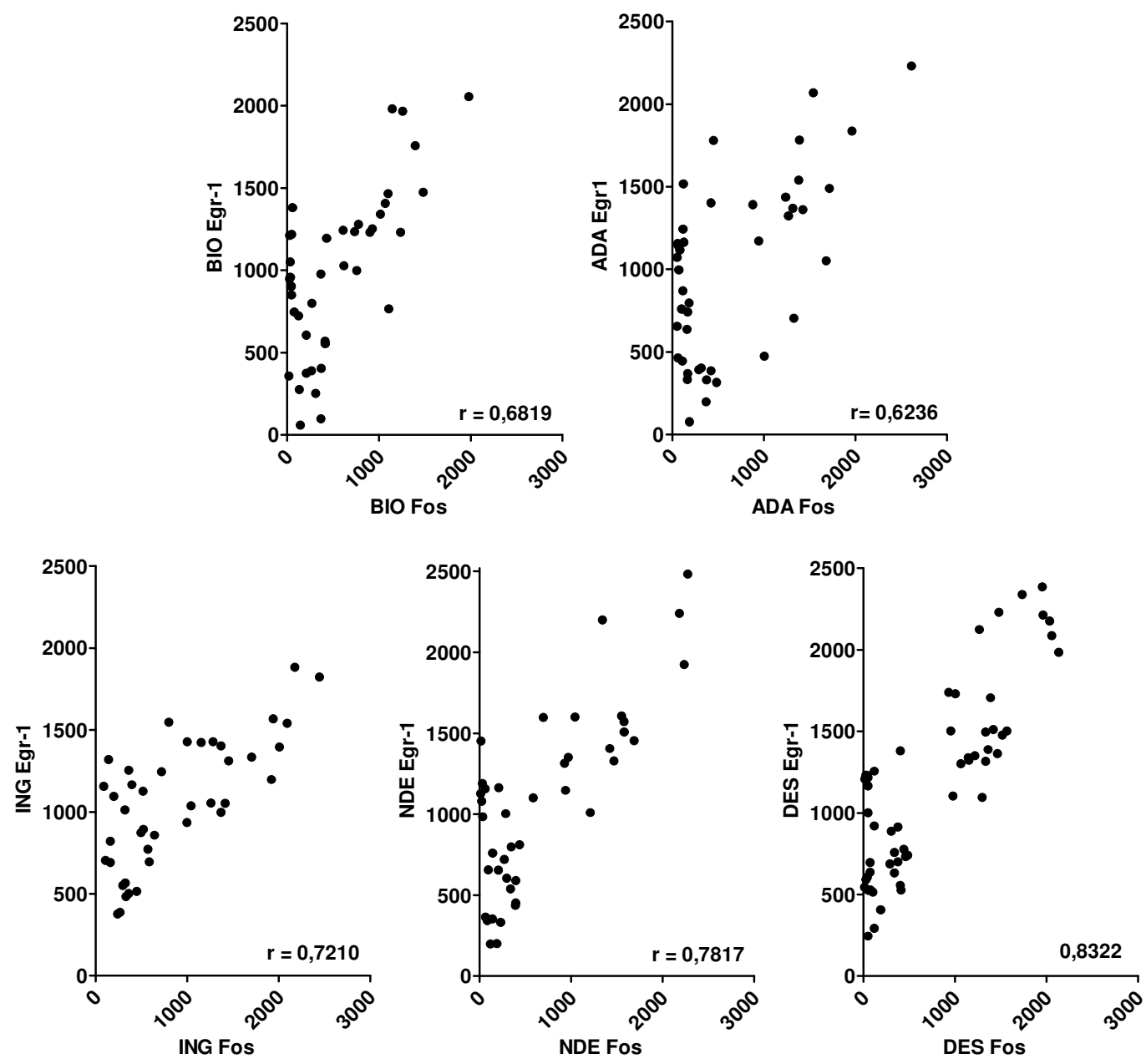

Figura 25 - Diagramas de dispersão dos dados de imunorreatividade dos marcadores Fos e Egr-1 dos cinco grupos experimentais, com os respectivos valores de correlação de Pearson (r).

A Figura 26 apresenta os resultados quando os dados são agrupados em grupo Fos e grupo Egr-1. O valor da densidade média de núcleos imunorreativos para Fos foi menor que o valor médio das estimativas para Egr-1, e a diferença encontrada entre os 
valores significante $\left(t_{222}=12,27, p<0,0001\right)$. $O$ alto coeficiente de correlação entre os dois grupos indica haver covariação entre os dados de imunorreatividade dos dois marcadores $(r=0,7281, p<0,0001)$.

A

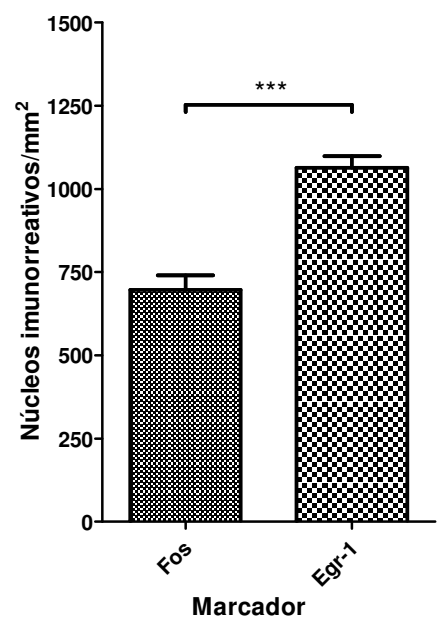

B

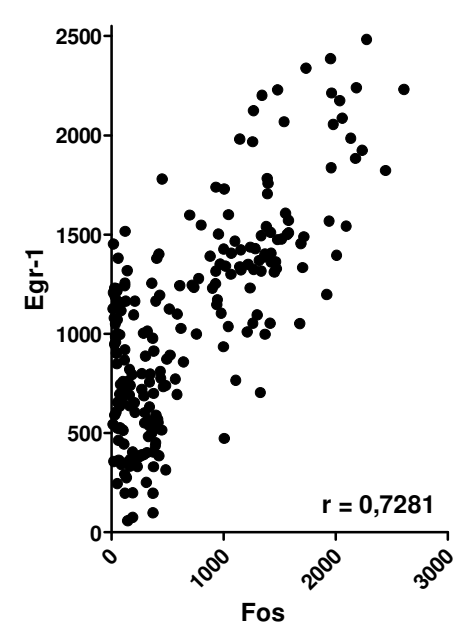

Figura 26 - Comparação dos valores de densidade média total $( \pm$ epm) de núcleos imunorreativos para Fos e Egr-1, que apresentou diferença significante (A, ***p < 0,001 ), e o diagrama de dispersão dos dados das duas proteínas com o respectivo coeficiente de correlação (B, $r=0,7281, p<0,0001)$.

As diferenças entre as densidades médias de núcleos imunorreativos para Fos e Egr-1 nas estruturas estudadas também podem ser visualizadas na Figura 27, onde os valores médios estimados para um mesmo grupo são colocados lado a lado. A figura revela que as maiores densidades de imunorreatividade, tanto para Fos como para Egr-1 foram encontradas na ACe em todos os grupos. Observa-se que os valores médios de densidade de núcleos imunorreativos para Fos são, em geral, menores que os valores médios para Egr-1 para todos os grupos e estruturas, sendo exceções a ABL e a ACe no grupo ING, para as quais os valores de imunorreatividade para Fos foram maiores do que os valores para Egr-1. A figura mostra ainda que os menores valores médios para Egr-1 foram estimados em sua maioria no GD, e que entre as estruturas que apresentam 
os valores mais baixos para Fos encontra-se o CA1. É também na área CA1 que foi observada a maior variação entre as estimativas para Fos e Egr-1. Nota-se que os valores médios dos grupos BIO, ADA e NDE apresentaram, para Fos, a mesma sequência de estruturas $(\mathrm{CA} 1<\mathrm{CPFm}<\mathrm{NSL}<\mathrm{GD}<\mathrm{ABL}<\mathrm{CA} 3<\mathrm{ACe})$. Sequência igual foi apresentada também pelos grupos BIO e NDE para Egr-1 (GD $<$ NSL $<$ CPFm $<$ CA1 $<$ $\mathrm{ABL}<\mathrm{CA} 3<\mathrm{ACe})$ porém a sequência do grupo ADA apresentou diferenças $(\mathrm{GD}<$ $\mathrm{NSL}<\mathrm{CPFm}<\mathrm{CA} 1<\mathrm{CA} 3<\mathrm{ABL}<\mathrm{ACe})$. Não foram detectadas semelhanças entre as sequências apresentadas pelos grupos ING e DES.

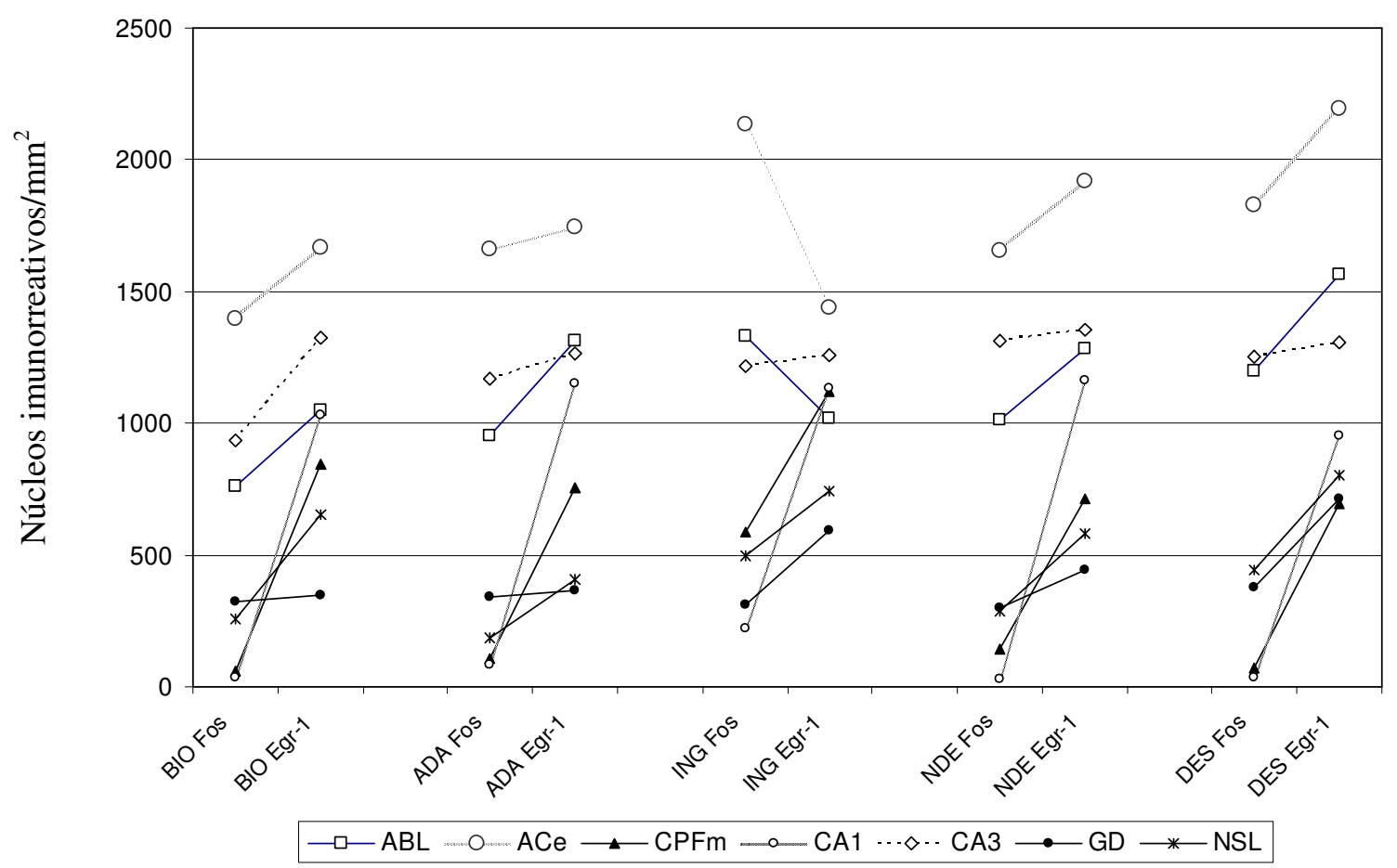

Figura 27 - Valores médios de densidade de núcleos imunorreativos por estrutura e marcador nos vários grupos. 


\section{DISCUSSÃO}

Este estudo procurou investigar os padrões de ativação neuronal em diferentes áreas do encéfalo de ratos submetidos ao modelo do desamparo aprendido, avaliando se a imunorreatividade para as proteínas Fos e Egr-1 estava diferencialmente alterada quando era constatada a não aprendizagem como função de história com estímulos aversivos incontroláveis, ou seja, o efeito de desamparo aprendido.

Conforme foi estabelecido nos objetivos deste trabalho, foram realizadas estimativas do número de núcleos imunorreativos para as proteínas Fos e Egr-1, prioritariamente para o hipocampo, córtex pré-frontal medial e amígdala. Os resultados gerais do experimento evidenciam diferenças estatisticamente significantes entre os grupos experimentais nas três estruturas selecionadas.

\subsection{CONSIDERAÇÕES GERAIS}

O modelo do desamparo aprendido utilizado neste trabalho originou-se do procedimento básico desenvolvido por Seligman e Maier (1967) que, posteriormente, na década de 80, sofreu alterações que aprimoraram a análise efetiva da aprendizagem operante na fase de teste (Hunziker, 2003). O procedimento modificado tem sido empregado regularmente no Laboratório de Análise Biocomportamental, nas pesquisas sobre as relações do organismo com aspectos incontroláveis do ambiente e suas influências em aprendizagens futuras. Os dados disponíveis na literatura, com os quais 
muitas vezes os resultados obtidos foram comparados, são provenientes de procedimentos com características diferentes do aqui utilizado, em especial no que diz respeito à variável dependente, ou seja, aprendizagem de fuga. As repercussões que essas mudanças têm para a análise do desamparo aprendido foram analisadas em detalhe em diversos trabalhos experimentais (Hunziker, 1981, 2003, 2005; Hunziker \& Santos, 2007). Como ponto central, esses estudos sugerem que, diferentemente da maioria dos trabalhos descritos na literatura (Maier \& Seligman, 1976; Peterson, Maier, \& Seligman, 1993) que avaliam mais provavelmente o déficit motor decorrente da incontrolabilidade dos choques, o procedimento aqui empregado demonstra que a variável dependente em estudo é a aprendizagem operante, ou seja, a mudança no comportamento do sujeito em função do reforço negativo. Com isso, pode-se analisar o efeito do desamparo como uma provável alteração nessa relação básica à adaptação dos organismos ao ambiente (a sensibilidade às suas consequências) como função de uma história com eventos aversivos intensos e incontroláveis.

Neste trabalho, por dificuldades técnicas de implantar o delineamento de tríades, foi utilizado o delineamento de duplas. Porém, como a literatura já demonstrou exaustivamente que os efeitos obtidos são decorrentes da incontrolabilidade dos choques, e não dos choques em si, considera-se que o presente estudo pode ser somado ao conjunto de trabalhos relativos aos múltiplos efeitos da aversividade incontrolável. Também por razões técnicas, a meta inicialmente estabelecida de oito sujeitos por grupo, que é o convencional em estudos sobre o desamparo aprendido, não foi atingida. Entretanto, o mínimo aqui utilizado $(n=6)$ é suficiente para que as análises dos dados comportamentais e imuno-histoquímicos sejam aceitáveis estatisticamente.

A técnica de imuno-histoquímica que foi utilizada para obtenção dos dados é 
uma ferramenta amplamente empregada na pesquisa básica para o estudo da expressão de proteínas com os mais diferentes propósitos nas diferentes estruturas biológicas (Bernardo, Lourenço, Cruz, Monteiro-Leal, Silva, Camisasca, Farina, \& Lins, 2009). O mecanismo básico desta técnica está no reconhecimento, de maneira específica, do antígeno (proteína) por um anticorpo. A interação entre o antígeno, que está sendo pesquisado, e o anticorpo é posteriormente visualizada por meio da formação de um complexo da enzima peroxidase e um agente cromógeno que irá catalisar o aparecimento da cor. Esta técnica indireta, isto é, que envolve duas reações antígenoanticorpo, é considerada bastante sensível em razão da amplificação do sinal que ocorre durante a reação dos anticorpos secundários com os diferentes sítios antigênicos do anticorpo primário. Além da sensibilidade dada pela amplificação, seriam algumas das vantagens da técnica o custo razoável, facilidade de utilização e a possibilidade de combinação com outras técnicas (Krukoff, 1998). Entretanto, também existem desvantagens que podem afetar a qualidade do trabalho. Entre os inúmeros fatores que podem afetar esse tipo de técnica temos a fixação do tecido, o tipo e duração do antígeno, a especificidade do anticorpo, a diluição do anticorpo, o sistema utilizado para detecção, entre outros (Walker, 2006). Em razão de sua sensibilidade, essa técnica semiquantitativa de imunomarcação tem sido amplamente utilizada para avaliações quantitativas, porém essas análises apresentam certas limitações (Walker, 2006) visto que as estimativas dependem da habilidade visual humana em conjunto com análise de imagem computadorizada ou contagem manual (Bernardo et al., 2009). No caso específico dos fatores de transcrição Fos e Egr-1, é grande o número de propósitos para os quais os mesmos têm sido aplicados, e a interpretação dos resultados deverá sempre levar em conta o contexto no qual esses produtos foram induzidos (Chaudhuri, 1997). 
O coeficiente de correlação de Pearson é amplamente utilizado em estudos de diversas áreas e pode ser interpretado como uma medida do grau de proximidade entre duas variáveis (Falk \& Well, 1997). Neste estudo o coeficiente de correlação de Pearson foi utilizado como medida da covariabilidade dos dados de imunorreatividade, entretanto, ainda que o mesmo possa ser útil para que alguns aspectos do estudo não passem despercebidos, quaisquer inferências devem ser realizadas com reserva.

\subsection{CARACTERÍSTICAS DA EXPRESSÃO DOS GENES}

A comparação dos dados de imunorreatividade para as proteínas Fos e Egr-1 mostra que os valores médios encontrados para Fos são, em geral, menores que os valores médios para Egr-1 para todos os grupos e estruturas, sendo as diferenças encontradas não significantes em alguns casos, mas significantes em sua maioria. Os valores apresentados na Figura 27 mostram uma imunorreatividade maior para Fos e menor para Egr-1 na ABL e na ACe do grupo ING. Esses valores muito provavelmente se devem à exposição aos choques do teste de fuga, que para os sujeitos desse grupo tiveram o efeito de uma novidade. Os resultados são consistentes com os dados da literatura que relatam que a expressão do gene egr-1 aparentemente requer uma exposição a estímulos mais específicos.

A avaliação da covariabilidade dos dados de imunorreatividade para Fos e Egr-1 por meio do cálculo do coeficiente de correlação (r) de Pearson evidenciou uma alta covariação dos dados gerais dos marcadores (Figura 26). Esse alto valor de correlação pode ser explicado pelo fato das estimativas para Fos e Egr-1, terem sido obtidas nos 
encéfalos dos mesmos sujeitos que estavam expostos aos mesmos estímulos ambientais. Os diagramas de dispersão da Figura 25 mostram que o índice de correlação entre os dois marcadores foi menor para os grupos que não receberam choques, aumentando com a exposição aos choques e com o efeito de dificuldade de aprendizagem, demonstrando a ocorrência de um direcionamento da expressão dos genes nos grupos experimentais.

Em relação aos coeficientes de correlação obtidos a partir dos valores para Fos e Egr-1 nas estruturas (Figura 23), observa-se que os maiores coeficientes foram obtidos entre os dados da ABL e ACe para o mesmo marcador, excetuando-se os valores para Fos e Egr-1 estimados no NSL que apresentaram alta correlação entre si e com os dados do GD para Egr-1. O NSL foi incluído no estudo em razão dos resultados de alguns trabalhos que evidenciaram uma redução na expressão do gene $c$-fos para o grupo dos animais com desamparo nesta estrutura (Steciuk et al., 1999; Ronan, Steciuk, Kramer, Kram, \& Petty, 2000; Huang et al., 2004), porém esses resultados não foram replicados no presente estudo (Figura 16). A não replicação dos resultados no NSL provavelmente se deve às diferenças existentes entre os delineamentos experimentais. Os altos coeficientes de correlação evidenciam existir uma covariabilidade entre os dados do GD para Egr-1 e os dados do NSL para ambos os marcadores, o que pode indicar interação funcional entre o NLS e o GD. Frey, Bergado e Frey (2003) observaram que a estimulação da ABL dentro de uma determinada janela de tempo pode transformar uma LTP temporária (early-LTP) em uma LTP duradoura (late LTP) no giro denteado de ratos, e esse resultado os estimulou a pesquisar como esse efeito no GD era desencadeado se não havia uma ligação direta com a ABL, tendo descoberto que o efeito no GD podia ser mediado via área septal.

Os dados sobre expressão basal dos genes $c$-fos e egr- 1 nas estruturas analisadas, 
obtidas a partir das médias do grupo não-estimulado intencionalmente BIO, mostram que a densidade de núcleos imunorreativos foi menor para Fos e maior para Egr-1 (Figura 22) para todas as regiões analisadas. As diferenças entre os dois marcadores, entretanto, não foram estatisticamente significantes na ACe e GD. Os dados encontrados por este trabalho são semelhantes aos resultados publicados por Herdegen et al. (1995) sobre a expressão basal das proteínas Fos e Egr-1. As exceções encontradas (ACe e GD) podem ser explicadas pelas diferenças nas condições experimentais em que os dados foram obtidos (Herdegen et al., 1995).

A análise dos dados de imunorreatividade para Fos e Egr-1 agrupados por estrutura mostra que o número de núcleos imunorreativos para Egr-1 continuou predominante (Figuras 8, 10, 11, 12, 13, 14 e 16) embora a diferença não tenha sido significativa na ACe (Figura 10). A predominância da expressão do gene egr-1 também se mostrou significante quando a análise separa os dados por grupo (Figura 24) ou reúne todos os dados obtidos em apenas dois grupos (Figura 26). Esse tipo de predominância da expressão do gene egr-1 é mencionada na literatura e sugere um tipo de atividade sináptica "fisiológica" permanente que seria consequência da ativação dos receptores NMDA e da exposição aos estímulos do dia a dia (Beckmann \& Wilce, 1997; Herdegen et al., 1995).

Conforme descrito na literatura, a maior densidade de marcação dos neurônios pela proteína Egr-1 esteve claramente restrita a algumas áreas do sistema nervoso central, e não foi detectada na substância branca do encéfalo (Beckmann \& Wilce, 1997). Segundo Beckmann e Wilce (1997) a expressão da proteína Egr-1 é baixa no giro denteado, maior na área $\mathrm{CA} 3$, e ainda maior na área CA1 do hipocampo. Neste experimento foram encontrados valores mais baixos no GD e mais altos nas áreas CA1 e 
CA3 do hipocampo, porém as estimativas no CA3 apresentaram valores médios maiores que os valores estimados no CA1. Resultado semelhante, de maior expressão de RNA mensageiro para Fos no CA3 e menor expressão no CA1, é mencionado por Kubik et al. (2007) e teria ocorrido durante a fase inicial de um experimento de discriminação de odor. Segundo esse autor, os padrões de expressão de dominância do CA1 ou CA3 parecem refletir diferentes condições de funcionamento do hipocampo.

A diferença significante na imunorreatividade para Fos encontrada na área CA1 do hipocampo entre os grupos BIO e ADA mostrou que o período de adaptação de três dias foi insuficiente para evitar a expressão decorrente da exposição dos animais a estímulos não relacionados ao tratamento com choques incontroláveis nessa estrutura, e indica a necessidade de que esse período seja prolongado em futuros estudos que visem analisar os efeitos da incontrolabilidade na expressão dos genes de ativação imediata.

\subsection{A EXPRESSÃO DE FOS E EGR-1 E O DESAMPARO APRENDIDO}

O resultado mais instigante do presente trabalho parece ter sido evidenciado no giro denteado do hipocampo, onde foi observado um aumento da densidade de núcleos imunorreativos para Egr-1 no grupo DES quando este foi comparado aos demais grupos, excetuando-se o grupo ING, que embora apresentando um valor médio menor, não apresentou diferença estatística significante (Figura 14). Conforme já mencionado anteriormente, o resultado observado para o grupo ING pode ter ocorrido em razão da exposição à novidade do choque elétrico apresentado no teste de fuga para os sujeitos desse grupo, ainda que se suponha que um aumento na ativação constatado para Egr-1 
apresente características de expressão diferenciadas de um aumento detectado para Fos.

Embora seja um grupo controle comportamental importante na análise dos dados do modelo do desamparo aprendido, o grupo ING aparentemente não foi um bom grupo controle experimental sob o ponto de vista da expressão dos genes de ativação imediata. A exposição à novidade do choque no teste de fuga também parece ser a explicação mais razoável para o aumento significativo da densidade de núcleos imunorreativos desse grupo em outras estruturas, a exemplo da maior expressão observada para o grupo ING no CPFm e na área CA1 do hipocampo, ambos para Fos (Figuras 11 e 12).

Os resultados obtidos neste experimento, que não mostraram diferenças significantes na imunorreatividade para Fos na área do GD (Figura 14), foram consistentes com os dados publicados por Castro-Alamancos et al. (1992) mas não replicaram os resultados de Huang et al. (2004) que mostraram ocorrer menor densidade de núcleos imunorreativos para Fos no giro denteado do hipocampo do grupo de sujeitos com desamparo em comparação com o grupo sem desamparo. Castro-Alamancos et al. (1992) estudaram a expressão do gene $c$-fos no giro denteado com a finalidade de identificar as diferenças entre os efeitos do aprendizado em condições aversivas dos efeitos relacionados aos choques. Esses pesquisadores não encontraram diferenças na imunorreatividade para Fos entre os animais com controle (TR) e sem controle (YK) sobre os choques, e chegaram à conclusão de que a presença da proteína Fos nessa área do hipocampo não estaria relacionada aos processos de memória e aprendizagem.

Com relação à amígdala, as diferenças significantes na densidade de núcleos imunorreativos para Egr-1 entre os grupos ING e DES, que foram encontradas tanto na ABL como na $\mathrm{ACe}$ (Figuras 8 e 10) e entre os grupos BIO e DES na $\mathrm{ABL}$, não são suficientes para qualquer afirmativa com relação à participação destas estruturas nos 
processos neurobiológicos relacionados ao desenvolvimento do fenômeno do desamparo aprendido, visto que as diferenças entre o grupo NDE e DES não foram estatisticamente significantes. Com relação aos dados de covariação, apesar dos dados estimados na ABL e ACe para Fos não terem apresentado diferenças significantes entre os grupos, foi observada uma alta correlação significante entre os dados de imunorreatividade da ABL e da ACe para Fos, o mesmo ocorrendo entre os dados estimados na ABL e na ACe para Egr-1, evidenciando uma covariabilidade (Figura 23) que reforça a ideia de interação funcional entre as duas estruturas neste estudo.

Os inúmeros estudos que demonstram haver relação entre a LTP e a expressão da proteína Egr-1, em conjunto com os resultados deste experimento que evidenciaram aumento da imunorreatividade para essa proteína no giro denteado no grupo DES, dão destaque uma série de estudos publicados sobre a amígdala basolateral e o giro denteado do hipocampo. Por exemplo, Ikegaya et al. (1995) mostraram que a estimulação da amígdala basolateral facilitou a ocorrência da potenciação de longo prazo no giro denteado do hipocampo, e Abe (2001), por meio de experimentos eletrofisiológicos em ratos anestesiados, conseguiu obter evidência direta de que a estimulação da amígdala modula a plasticidade sináptica no hipocampo, confirmando os dados que tinham sido obtidos por Jas, Almaguer, Frey e Bergado (2000) e por Akirav e Richter-Levin (1999). Akirav e Richter-Levin (2006) posteriormente confirmaram que o efeito de ativação da ABL sobre o GD é bifásico, podendo produzir aumento e inibição da plasticidade sináptica no hipocampo. Akirav e Richter-Levin (2006) afirmam que uma questão chave a ser respondida seria saber em que condições os efeitos de ativação da amígdala sobre o hipocampo passariam a gerar prejuízos e não benefícios às funções de memória e aprendizagem. Interessante que Baumgärtel, Genoux, Welzl, Tweedie-Cullen, Koshibu, 
Livingstone-Zatchej, Mamie e Mansuy (2008) relatam que descobriram que a proteína calcineurina fosfatase, um potente regulador negativo da sinalização neuronal, está inibida na amígdala durante a formação da memória aversiva (isto é, a retenção da lembrança do evento aversivo pelo organismo) enquanto a proteína Egr-1 estaria ativada e a expressão da proteína Fos permaneceria sem modificações. Posteriormente, utilizando camundongos transgênicos, esses pesquisadores teriam observado ainda que a inibição da proteína calcineurina fosfatase e a expressão aumentada da proteína Egr-1 fortalecem a retenção e aumentam a resistência da memória à extinção.

Outro trabalho, que estudou o impacto da controlabilidade e incontrolabilidade em labirinto aquático na atividade do hipocampo e amígdala de ratos, detectou uma melhora na LTP no GD para o grupo incontrolável, prejuízo da LTP na área CA1 do HIP para os grupos controlável e incontrolável, e redução na LTP no núcleo basal da amígdala também para ambos os grupos (Kavushansky, Vouimba, Cohen, \& RichterLevin, 2006). Esses resultados, que segundo os autores sugere a indução de plasticidade pelo estresse incontrolável (Kavushansky et al., 2006), aparentemente são contrários aos relatos de outros pesquisadores que observaram prejuízos na LTP hipocampal (Shors, Foy, Levine, \& Thompson, 1990; Maroun \& Richter-Levin, 2003; Kim, Song, \& Kosten, 2006). Ryan, Vollmayr, Klyubin, Gass, \& Rowan (2009) observaram prejuízos na plasticidade sináptica na área dorsal do hipocampo após choques incontroláveis, mas concluíram que esse efeito não estaria diretamente ligado à indução do desamparo nos animais. Observa-se que os resultados relatados por Kavushansky et al. (2006) apresentam certa similaridade com os dados que são aqui apresentados, pelas alterações observadas no GD para Egr-1 no grupo incontrolável (DES), e pelas reduções na imunorreatividade para Fos no CA1 de ambos os grupos, controlável e incontrolável, 
deste estudo.

A formação de novas memórias tem sido baseada na hipótese de que a ativação de cascatas moleculares nos neurônios resultaria em modificações duradouras na estrutura e função das sinapses, com a potenciação de longo prazo exercendo um papel essencial nesse mecanismo de plasticidade sináptica (Bruel-Jungerman et al., 2006). A neurogênese no hipocampo, em áreas como o giro denteado, tem sido estudada como uma possível forma explicar o mecanismo da memória pela plasticidade neuronal (Bruel-Jungerman et al., 2006; Bruel-Jungerman, Davis, \& Laroche, 2007; Deng, Saxe, Gallina, \& Gage, 2009), mas ainda permanece obscuro se a neurogênese realmente participa desse mecanismo (Deng, Aimone, \& Gage, 2010).

As hipóteses atuais de indução e manutenção da depressão têm sugerido o envolvimento da neurogênese hipocampal no desenvolvimento da depressão (Paizanis et al., 2007), no sentido de que uma redução na proliferação das células granulares do GD induzida pelo estresse resultaria no desenvolvimento dos episódios depressivos (Chen et al., 2006; Duman, 2002a, 2002b). Como foi mencionado na Introdução, Vollmayr et al. (2007) argumentam contra essa hipótese com base nos resultados de um estudo realizado no modelo do desamparo aprendido (Vollmayr, Simonis, Weber, Glass, \& Henn, 2003). Esse estudo mostrou que uma pequena e não significativa redução da proliferação celular ocorre no GD de animais com e sem desamparo após choques inescapáveis de 0,8 mA (com duração não especificada) nas patas. Nesse estudo, os pesquisadores também mostraram que o estresse da imobilização era suficiente para provocar uma redução de $35 \%$ na taxa de proliferação celular no giro denteado em animais que não apresentaram o desamparo aprendido no teste (15 tentativas, $0,8 \mathrm{~mA}$, com duração de 60 s cada) realizado 24 horas depois. Os autores analisam que estes resultados sugerem que 
o processo fisiológico de desenvolvimento do desamparo aprendido não envolve alterações na taxa de formação de novas células (Vollmayr et al., 2003). Os autores lembram, entretanto, que embora as modificações agudas na proliferação celular não estejam relacionadas à indução do fenômeno, ainda existe a possibilidade de que as reduções celulares detectadas posteriormente possam estar relacionadas com a manutenção do comportamento (Vollmayr et al., 2003). Já Fornal et al. (2007) mostram uma outra possibilidade. Eles estudaram a proliferação celular em ratos que receberam 100 choques de 1,0 mA na cauda, com duração de $5 \mathrm{~s}$ cada, encontrando um decréscimo de $18 \%$ no número de células após um período de sete dias da sessão de choques. Esses autores chegaram à conclusão que a redução observada na proliferação celular pode ter alguma relação com os altos níveis de corticosterona, hipótese que seria consistente com os resultados relatados em outros trabalhos (Brummelte \& Galea, 2010).

O aumento da imunorreatividade para Egr-1 detectado no GD do grupo DES não contribui para elucidar a ocorrência ou não de proliferação celular nessa estrutura pois, segundo dados da literatura, o gene egr-1 pode atuar regulando a proliferação celular, aumentando-a ou reduzindo-a, existindo um longo caminho a ser percorrido até que tais aspectos reguladores sejam melhor compreendidos.

Os resultados obtidos para a proteína Fos no CPFm e na área CA1 do hipocampo para o grupo ING apresentaram diferenças significantes na comparação com todos os outros grupos estudados (Figuras 11 e 12). A realização de novas análises dos dados excluindo esse grupo evidenciou a presença de diferença significante entre os grupos BIO e NDE no CPFm (Figura 17). Essa diferença pode ser explicada pelas condições de exposição aos estímulos que são distintas entre esses dois grupos. Os sujeitos do grupo BIO não foram expostos aos estímulos aversivos intensos aos quais foram submetidos os 
sujeitos do grupo NDE, o que resultaria em menor expressão da proteína Fos no grupo BIO.

Uma menor ativação do CPFm para Fos no grupo DES foi evidenciada quando os grupos NDE e DES foram analisados isoladamente (Figura 20). Os sujeitos desses dois grupos foram expostos ao mesmo tratamento com choques, apresentando desempenhos diferentes quando o teste de aprendizagem foi realizado. Nessa comparação, a maior ativação para Fos foi observada no CPFm do grupo NDE. Esses dados são consistentes com resultados obtidos por Huang et al. (2004) que observaram uma maior imunorreatividade no CPFm do grupo sem desamparo que no grupo controle, que pode ser comparado ao grupo BIO (Figura 17). No trabalho de Huang et al. (2004), a imunorreatividade para Fos no CPFm dos animais com desamparo foi menor do que a imunorreatividade no grupo sem desamparo porém maior que a do grupo controle, mas essas diferenças não se mostraram significantes. Sobre esses resultados os pesquisadores comentaram que a descoberta sugeria que o estresse pode ter efeitos na atividade neuronal no CPFm, mas que não representaria algo importante com relação ao comportamento do desamparo aprendido. Essa conclusão não é sustentada pelos estudos conduzidos por Amat e colaboradores, que têm sugerido que o CPFm pode ser muito importante para a detecção e processamento da controlabilidade (Amat, Baratta, Paul, Bland, Watkins, \& Maier, 2005; Amat, Paul, Zarza, Watkins, \& Maier, 2006; Baratta, Christianson, Gomez, Zarza, Amat, Masini, Watkins, \& Maier, 2007).

De acordo com Amat et al. (2005), o CPFm ventral não seria uma estrutura crítica para a aquisição do controle da resposta de fuga, mas teria importância na detecção da contingência, agindo na regulação do funcionamento de outras estruturas envolvidas nas respostas aos eventos aversivos, e também na utilização da experiência 
prévia para modular o impacto de uma eventual exposição posterior a estímulos aversivos incontroláveis (Amat et al., 2006). Sob essa perspectiva, os resultados aqui obtidos, de menor imunorreatividade no CPFm para Fos no grupo DES, indicariam uma falta de ativação neuronal decorrente da não detecção da contingência pelo sujeito. Em termos comportamentais, a não detecção da contingência pelo sujeito poderia ser interpretada como uma insensibilidade dos animais às contingências de reforçamento, e seria observada quando os sujeitos, apesar de experimentarem a contingência de fuga em vigor, não aprendem essa resposta (Hunziker, 2003). A maior imunorreatividade para Fos detectada no CPFm no grupo NDE em comparação ao grupo DES, por sua vez, poderia sugerir que esse grupo apresentou ativação neuronal suficiente para conseguir detectar a contingência em vigor e aprender a resposta, mostrando estar sensível à contingência de reforçamento ao não apresentar defasagens significantes na aprendizagem de fuga.

A hipótese mencionada por Amat e colaboradores apresenta consistência com a suposição de Drevets et al. (2008) de que o CPFm e os circuitos que o conectam com outras estruturas límbicas e corticais estariam disfuncionais na depressão em humanos, e também é compatível com a sugestão de que, no transtorno de estresse pós-traumático, a ativação da amígdala estaria aumentada em razão da menor inibição dessa estrutura pelo CPFm. Outro experimento, realizado por Kim, Jo, Kim, Kim, e Choi (2010), traria evidências nessa mesma direção. Esses autores também relatam uma redução na densidade de núcleos imunorreativos para Fos no CPFm de ratos que apresentaram déficits no aprendizado de extinção respondente, o que os levou a concluir que a falta de ativação do CPFm, mais especificamente da região infralímbica, pode estar relacionada a esse déficit. Os estudos sobre extinção respondente são importantes para os 
pesquisadores do transtorno de estresse pós-traumático, distúrbio para o qual o desamparo aprendido também é proposto como modelo animal. Os déficits no aprendizado de extinção explicariam os sinais e sintomas de re-experimentação que caracterizam o distúrbio traumático nos pacientes (Kim et al., 2010).

Akirav e Maroun (2007) afirmam que uma disfunção no circuito CPFm-AMI pode ocorrer após uma experiência de exposição a estímulos aversivos, e que tal disfunção também afetaria a área CA1 do hipocampo. No experimento aqui descrito não foi observada diferença significante entre os grupos NDE e DES na área CA1, mas foi detectado um efeito de covariação entre os dados do CPFm e da área CA1 do hipocampo para a proteína Fos. Como mencionado anteriormente, em condições normais a ABL, que seria importante na consolidação das lembranças de eventos que eliciam respostas de medo e emocionais, deveria ser inibida pela ativação do CPFm (Akirav \& Maroun, 2007), e esse efeito de inibição também agiria sobre a ACe, apesar das poucas projeções do CPFm para esta estrutura (Likhtik et al, 2005).

Os resultados experimentais para Fos aqui relatados mostram que, para o grupo ING, o aumento da proteína Fos no CPFm foi acompanhado pelo aumento não significante da imunorreatividade do mesmo marcador na $\mathrm{ABL}$ e na $\mathrm{ACe}$, e no caso do grupo DES o resultado seria o oposto, isto é, ocorreu uma pequena redução significante na ativação do CPFm na comparação com o grupo NDE, que foi acompanhada por um aumento não significante na $\mathrm{ABL}$ e na ACe. Analisando os resultados de imunorreatividade para a proteína Egr-1, o aumento não significante da ativação no CPFm do grupo ING foi acompanhado por uma quase estabilidade na ativação na ABL e ACe, sendo que, para o grupo DES, o valor para Egr-1 no CPFm manteve-se muito pouco reduzido em contraste com o aumento observado na ABL e na ACe para esse 
grupo. A explicação dada por Akirav e Maroun (2007), no entanto, adquire uma maior consistência se a análise dos dados dos marcadores Fos e Egr-1 forem cruzados. Neste caso, a redução na ativação para Fos no CPFm do grupo DES seria acompanhada por um aumento na ativação para Egr-1 na ABL e ACe do grupo DES.

Os estudos realizados em pacientes com o transtorno de estresse pós-traumático, principalmente de neuroimagem, que evidenciaram a ocorrência de aumento da ativação da amígdala, redução da ativação do córtex pré-frontal medial e prejuízos funcionais no hipocampo dos pacientes, apresentam consistência com os dados que evidenciaram para o grupo DES aumento parcialmente significante na ativação da ABL e ACe para Egr-1, redução da ativação do CPFm para Fos e alterações na ativação neuronal no GD do hipocampo para Egr-1. Os resultados deste experimento poderiam então ser explicados por uma baixa inibição da amígdala pelo CPFm que, consequentemente, levaria a um efeito de modulação positiva dessa estrutura sobre o giro denteado, incrementando a LTP e produzindo o aumento da proteína Egr-1 que, por sua vez, poderia modular negativamente a proliferação celular na região hipocampal.

Os resultados do presente experimento revelam alterações na imunorreatividade para as proteínas Fos e Egr-1 em estruturas que são consideradas importantes para o estudo do estresse, da memória e aprendizagem. As evidências diretas do envolvimento do gene egr-1 na manutenção da LTP, consolidação e reconsolidação de memórias, e aprendizagem (Jones et al., 2001; Davis et al., 2003; Poirier et al., 2008) sugerem que o desamparo aprendido está implicado nos mecanismos correspondentes. Mas ainda que a potenciação de longo prazo promova a proliferação de novos neurônios no giro denteado (Bruel-Jungerman et al., 2006), e a LTP rapidamente induza a expressão da proteína Egr-1 (Wisden et al., 1990; Bozon et al., 2002), a maior imunorreatividade para Egr-1 
no giro denteado observada no grupo DES não é evidência que possa relacionar o desenvolvimento do desamparo aprendido com a neurogênese. Os mecanismos moleculares que regulam a proliferação celular no GD não são conhecidos (BruelJungerman et al., 2006), e a ligação da neurogênese com os mecanismos de memória e aprendizagem ainda não está clara (Deng et al., 2010), sendo que os resultados obtidos por Vollmayr et al. (2003) reduzem as possibilidades de que a neurogênese tenha relação com o desamparo aprendido. Apesar disso, os resultados aqui relatados destacam os mecanismos de regulação da proliferação celular como um tema a ser estudado.

O desenvolvimento do desamparo aprendido implica em algum tipo de alteração fisiológica que deveria ocorrer em menos de 24 horas, tempo após o qual o fenômeno já é detectado. Os resultados do estudo aqui descrito sugerem que essa alteração deve envolver a expressão do gene egr-l no giro denteado do hipocampo e o gene $c$-fos no córtex pré-frontal, e talvez amígdala, que poderiam atuar no curto prazo provavelmente nos mecanismos responsáveis pela aquisição da lembrança traumática, e também no longo prazo reduzindo o volume hipocampal por meio da regulação da proliferação celular.

Os dados provenientes da literatura sobre a expressão dos genes de ativação imediata estudados aqui destacam as características reguladoras desses genes, que podem resultar em aumento ou redução da proliferação celular, a exemplo do envolvimento do gene egr-1 na redução ou aumento do crescimento celular de tumores (Calogero et al., 2004; Baron, Adamson, Calogero, Ragona, \& Mercola, 2006). Já em 1997 Beckmann e Wilce mencionavam as propriedades reguladoras dos fatores de transcrição da família Egr, que poderiam atuar em muitas proteínas com funções diferentes nos diversos tipos de célula. A afirmação desses autores de que muita 
pesquisa ainda seria necessária para determinar o papel regulador exato desses genes in vivo e estabelecer como tais proteínas funcionam, continua válida.

As evidências experimentais dos estudos têm sugerido funções importantes para as estruturas onde foram encontradas as diferenças significantes neste trabalho. Sugerese que córtex pré-frontal medial normalmente inibe a ativação da amígdala (Akirav \& Maroun, 2007) ou detecta a contingência em uma situação de controlabilidade (Amat et al., 2006), enquanto a amígdala modula a ativação do giro denteado (Akirav \& RichterLevin, 2006), que estaria implicado na memória e aprendizagem. As hipóteses explicativas fornecidas pela literatura sobre os mecanismos neurobiológicos, entretanto, ainda apresentam muitas contradições, certamente em razão da complexidade dos organismos, dos inúmeros fatores e variáveis diferentes entre os estudos que são realizados, e dos pontos ainda obscuros que precisam ser revelados por novas descobertas. Os resultados deste experimento, no entanto, fornecem indícios neurobiológicos de que o modelo do desamparo aprendido é um bom modelo para o estudo de distúrbios como a depressão e o transtorno de estresse pós-traumático. Os resultados mais importantes deste experimento foram evidenciados nas estruturas encefálicas que correspondem às áreas onde foram detectadas as alterações nos pacientes com esses distúrbios, e os resultados também apresentam uma razoável consistência com algumas das evidências observadas em outros estudos realizados sobre temas relacionados a essas condiçõos. 


\section{CONCLUSÃO}

O presente trabalho disponibilizou informações importantes para uma melhor compreensão do fenômeno do desamparo aprendido, tendo acrescentado dados que contribuem para o entendimento dos processos neurais envolvidos na aprendizagem e memória em condições aversivas. Os resultados relatados neste trabalho conduziram às seguintes conclusões:

1. A imunorreatividade foi diferencialmente alterada no CPFm para Fos e no GD para Egr-1 quando foi constatada a não aprendizagem.

2. As características de expressão dos genes $c$-fos e egr-l foram distintas nas diversas estruturas analisadas.

3. Os resultados evidenciados na amígdala, no córtex pré-frontal medial e no giro denteado do hipocampo indicam que essas estruturas podem ser funcionalmente importantes para o desenvolvimento do fenômeno do desamparo aprendido.

4. As evidências existentes sobre as características funcionais dessas estruturas sugerem que os mecanismos neurobiológicos da memória e aprendizagem estão implicados no desenvolvimento do desamparo aprendido.

5. Os resultados gerais do trabalho indicam que os estudos realizados no modelo do desamparo aprendido podem ser úteis para a compreensão dos mecanismos neurobiológicos envolvidos no desenvolvimento da depressão e do transtorno de estresse pós-traumático. 


\section{REFERÊNCIAS BIBLIOGRÁFICAS}

Abe, K. (2001). Modulation of hippocampal long-term potentiation by the amygdala: a synaptic mechanism linking emotion and memory. Japanese Journal of Pharmacology, 86(1), 18-22.

Abel, T., \& Lattal, M. (2001). Molecular mechanisms of memory acquisition, consolidation and retrieval. Current Opinion in Neurobiology, 11(2), 180-187.

Abraham, W. C. (2003). How long will long-term potentiation last? Philosophical Transactions of the Royal Society of London. Series B, Biological Sciences, 358(1432), 735-744.

Abraham, W. C., Logan, B., Greenwood, J. M., \& Dragunow, M. (2002). Induction and experience-dependent consolidation of stable long-term potentiation lasting months in the hippocampus. The Journal of Neuroscience, 22(21), 9626-9634.

Akirav, I., \& Maroun, M. (2007). The role of the medial prefrontal cortex-amygdala circuit in stress effects on the extinction of fear. Neural Plasticity, ID 30873.

Akirav, I., \& Richter-Levin, G. (1999). Priming stimulation in the basolateral amygdala modulates synaptic plasticity in the rat dentate gyrus. Neuroscience Letters, 270(2), 83-86.

Akirav, I., \& Richter-Levin, G. (2006). Factors that determine the non-linear amygdala influence on hippocampus-dependent memory. Dose Response, 4(1), 22-37. 
Alberini, C. M. (2008). The role of protein synthesis during the labile phases of memory: revisiting the skepticism. Neurobiology of Learning and Memory, $89(3), 234-246$.

Alberini, C. M. (2009). Transcription factors in long-term memory and synaptic plasticity. Physiological Reviews, 89(1), 121-145.

Amat, J., Baratta, M. V., Paul, E., Bland, S. T., Watkins, L. R., \& Maier, S. F. (2005). Medial prefrontal cortex determines how stressor controllability affects behavior and dorsal raphe nucleus. Nature Neuroscience, 8(3), 365-371.

Amat, J., Paul, E., Zarza, C., Watkins, L. R., \& Maier, S. F. (2006). Previous experience with behavioral control over stress blocks the behavioral and dorsal raphe nucleus activating effects of later uncontrollable stress: role of the ventral medial prefrontal cortex. The Journal of Neuroscience, 26(51), 13264-13272.

Barad, M., Gean, P-W., \& Lutz, B. (2006). The role of the amygdala in the extinction of conditioned fear. Biological Psychiatry, 60(4), 322-328.

Baratta, M. V., Christianson, J. P., Gomez, D. M., Zarza, C. M., Amat, J., Masini, C. V., Watkins, L. R., \& Maier, S. F. (2007). Controllable versus uncontrollable stressors bi-directionally modulate conditioned but not innate fear. Neuroscience, 146(4), 1495-1503.

Baron, V., Adamson, E. D., Calogero, A., Ragona, G., \& Mercola, D. (2006). The transcription factor Egr1 is a direct regulator of multiple tumor suppressors including TGF $\beta 1$, PTEN, p53 and fibronectin: Egr-1 is a potential target of gene therapy for prostate cancer. Cancer Gene Therapy, 13(2), 115-124. 
Baumgärtel, K., Genoux, D., Welzl, H., Tweedie-Cullen, R. Y., Koshibu, K., Livingstone-Zatchej, M., Mamie, C. \& Mansuy, I. M. (2008). Control of the establishment of aversive memory by calcineurin and Zif268. Nature Neuroscience, 11(5), 572-578.

Beckmann, A. M., \& Wilce, P. A. (1997). Egr transcription factors in the nervous system. Neurochemistry International, 31(4), 477-510.

Bernardo, V., Lourenço, S. Q. C., Cruz, R., Monteiro-Leal, R. H., Silva, L. E., Camisasca, D. R., Farina, M., \& Lins, U. (2009). Reproducibility of immunostaining quantification and description of a new digital image processing procedure for quantitative evaluation of immunohistochemistry in Pathology. Microscopy and Microanalysis, 15(4), 353-365.

Bliss, T. V., Collingridge, G. L., \& Morris, R. G. (2003). Introduction. Long-term potentiation and structure of the issue. Philosophical Transactions of the Royal Society of London. Series B, Biological Sciences. 358(1432), 607-611.

Bozon, B., Davis, S., \& Laroche, S. (2002). Regulated transcription of the immediateearly gene zif268: mechanisms and gene dosage-dependent function in synaptic plasticity and memory formation. Hippocampus, 12(5), 570-577.

Bracewell, J. R., \& Black, A. H. (1974). The effects of restraint and noncontingent preshock on subsequent escape learning in the rat. Learning and Motivation, 5, 53-69.

Branch, M. N. (1977). On the role of "memory" in the analysis of behavior. Journal of the Experimental Analysis of Behavior, 28, 171-179. 
Bremner, J. D., Elzinga, B., Schmahl, C., \& Vermetten, E. (2008). Structural and functional plasticity of the human brain in posttraumatic stress disorder. Progress in Brain Research, 167, 171-186.

Bremner J. D., Innis, R. B., Southwick, S. M., Staib, L., Zoghbi, S., \& Charney, D. S. (2000). Decreased benzodiazepine receptor binding in prefrontal cortex in combat-related posttraumatic stress disorder. The American Journal of Psychiatry, 157(7), 1120-1126.

Bremner, J. D., Narayan, M., Staib, L. H., Southwick, S. M., McGlashan, T., \& Charney, D. S. (1999). Neural correlates of memories of childhood sexual abuse in women with and without posttraumatic stress disorder. The American Journal of Psychiatry, 156(11), 1787-1795.

Bremner, J. D., Southwick, S. M., \& Charney, D. S. (1991). Animal models for the neurobiology of trauma. PTSD Research Quarterly, 2(4), 1-7.

Breslau, N., Davis, G. C., Andreski, P., \& Peterson, E. (1991). Traumatic events and posttraumatic stress disorder in an urban population of young adults. Archives of General Psychiatry, 48(3), 216-222.

Bruel-Jungerman, E., Davis, S., \& Laroche, S. (2007). Brain plasticity mechanisms and memory: a party of four. The Neuroscientist, 13(5), 492-505.

Bruel-Jungerman, E., Davis, S., Rampon, C., \& Laroche, S. (2006). Long-term potentiation enhances neurogenesis in the adult dentate gyrus. The Journal of Neuroscience, 26(22), 5888-5893. 
Brummelte, S., \& Galea, L. A. (2010). Chronic high corticosterone reduces neurogenesis in the dentate gyrus of adult male and female rats. Neuroscience, doi: 10.1016/j.neuroscience.2010.04.023.

Calogero, A., Lombari, V., De Gregorio, G., Porcellini, A., Ucci, S., Arcella, A., Caruso, R., Gagliardi, F. M., Gulino, A., Lanzetta, G., Frati, L., Mercola, D., \& Ragona, G. (2004). Inhibition of cell growth by Egr-1 in human primary cultures from malignant glioma. Cancer Cell International, 4(1).

Canteras, N. S. (2003). Análise crítica dos sistemas neurais envolvidos nas respostas de medo inato. Revista Brasileira de Psiquiatria, 25(Supl 2), 21-25.

Cardinal, R. N., Parkinson, J. A., Hall, J., \& Everitt, B. J. (2002). Emotion and motivation: the role of the amygdala, ventral striatum and prefrontal cortex. Neuroscience and Biobehavioral Reviews, 26(3), 321-352.

Castro-Alamancos, M. A., Borrell, J., \& Garcia-Segura, I. M. (1992). Performance in an escape task induces Fos-like immunoreactivity in a specific area of the motor cortex of the rat. Neuroscience, 49(1), 157-162.

Catania, A. C. (1999). Aprendizagem: comportamento, linguagem e cognição. $4^{\mathrm{a}}$ ed. (D.G. Souza, Trad.) Porto Alegre: Artmed. (Obra original publicada em 1998).

Charlton, B. G. (1992). Stress. Journal of Medical Ethics, 18(3), 156-159.

Chaudhuri, A. (1997). Neural activity mapping with inducible transcription factors. Neuroreport, 8(16), v-ix. 
Chaudhuri, A., Zangenehpour, S., Rahbar-Dehgan, F., \& Ye, F. (2000). Molecular maps of neural activity and quiescence. Acta Neurobiologiae Experimentalis, 60(3), 403-410.

Chen, H., Pandey, G. N., \& Dwivedi, Y. (2006). Hippocampal cell proliferation regulation by repeated stress and antidepressants. Neuroreport, 17(9), 863-867.

Cryan, J. F., Markou, A., \& Lucki, I. (2002). Assessing antidepressant activity in rodents: recent developments and future needs. Trends in Pharmacological Sciences, 23(5), 238-245.

Darwich, R. A., \& Tourinho, E. Z. (2005). Respostas emocionais à luz do modo causal de seleção por consequências. Revista Brasileira de Terapia Comportamental e Cognitiva, VII(1), 107-118.

Davis, S., Bozon, B., \& Laroche, S. (2003). How necessary is the activation of the immediate early gene zif 268 in synaptic plasticity and learning? Behavioural Brain Research, 142(1-2), 17-30.

Davis, M., \& Whalen, P. J. (2001). The amygdala: vigilance and emotion. Molecular Psychiatry, 6(1), 13-34.

Delamater, A. R. (2004). Experimental extinction in Pavlovian conditioning: behavioural and neuroscience perspectives. The Quarterly Journal of Experimental Psychology. B, Comparative and Physiological Psychology, 57(2), 97-132. 
Deng, W., Aimone, J. B., \& Gage, F. H. (2010). New neurons and new memories: how does adult hippocampal neurogenesis affect learning and memory? Nature Reviews Neuroscience, 11(5), 339-350.

Deng, W., Saxe, M. D., Gallina, I. S., \& Gage, F. H. (2009). Adult-born hippocampal dentate granule cells undergoing maturation modulate learning and memory in the brain. The Journal of Neuroscience, 29(43), 13532-13542.

Donahoe, J. W., \& Palmer, D. C. (1994). Learning and complex behavior. Boston: Allyn and Bacon.

Dragunow, M., \& Faull, R. (1989). The use of $c$-fos as a metabolic marker in neuronal pathway tracing. Journal of Neuroscience Methods, 29(3), 261-265.

Drevets, W. C. (1999). Prefrontal cortical-amygdalar metabolism in major depression. Annals of the New York Academy of Sciences, 877, 614-637.

Drevets, W. C., Price, J. L., \& Furey, M. L. (2008). Brain structural and functional abnormalities in mood disorders: implications for neurocircuitry models of depression. Brain Structure and Function, 213(1-2), 93-118.

D'Sa, C., \& Duman, R. S. (2002). Antidepressants and neuroplasticity. Bipolar Disorders, 4(3), 183-194.

Duman, R. S. (2002a). Pathophysiology of depression: the concept of synaptic plasticity. European Psychiatry, 17(Suppl.3), 306-310.

Duman, R. S. (2002b). Synaptic plasticity and mood disorders. Molecular Psychiatry, 7, S29-S34. 
Durchdewald, M., Angel, P., \& Hess, J. (2009). The transcription factor Fos: a Janustype regulator in health and disease. Histology and Histopathology, 24(11), 1451-1461.

Elzinga, B. M., \& Bremner, J. D. (2002). Are the neural substrates of memory the final common pathway in posttraumatic stress disorder (PTSD)? Journal of Affective Disorders, 70(1), 1-17.

Falk, R., \& Well, A.D. (1997). Many faces of the correlation coefficient. Journal of Statistics Education, 5(3).

Ferrari, E. A. M., Toyoda, M. S. S., Faleiros, L., \& Cerutti, S. M. (2001). Plasticidade neural: relações com o comportamento e abordagens experimentais. Psicologia: Teoria e Pesquisa, 17(2), 187-194.

Ferster, C. B. (1973). A functional analysis of depression. American Psychologist, 28, $857-870$.

Fisch, G. S., \& Holmes, A. (2007). Recent developments in the use of animal models of psychiatric disease - introduction to special issue. Behavior Genetics, 37(1), 259263.

Foa, E. B., Zinbarg, R., \& Rothbaum, B. O. (1992). Uncontrollability and unpredictability in post-traumatic stress disorder: an animal model. Psychological Bulletin, 112(2), 218-238.

Frankland, P. W., \& Bontempi, B. (2005). The organization of recent and remote memories. Nature Reviews, 6(2), 119-130. 
Frey, S., Bergado, J. A., \& Frey, J. U. (2003). Modulation of late phases of long-term potentiation in rat dentate gyrus by stimulation of the medial septum. Neuroscience, 118(4), 1055-1062.

Fuchs, E., Czéh, B., Kole, M. H., Michaelis, T., \& Lucassen, P. J. (2004). Alterations of neuroplasticity in depression: the hippocampus and beyond. European Neuropsychopharmacology, 14(Suppl 5), 481-490.

Gallitano-Mendel, A., Izumi, Y., Tokuda, K., Zorumski, C. F., Howell, M. P., Muglia, L. J., Wozniak, D. F., \& Milbrandt, J. (2007). The immediate early gene early growth response gene 3 mediates adaptation to stress and novelty. Neuroscience, 148(3), 633-643.

Glazer, H. I., \& Weiss, J. M. (1976a). Long-term and transitory interference effects. Journal of Experimental Psychology: Animal Behavior Processes, 2(3), 191-201.

Glazer, H. I., \& Weiss, J. M. (1976b). Long-term interference effects: an alternative to learned helplessness. Journal of Experimental Psychology: Animal Behavior Processes, 2, 202-213.

Gruenberg, A. M., Goldstein, R. D., \& Pincus, H. A. (2005). Classification of depression: research and diagnostic criteria: DSM-IV and ICD-10. In J. Licinio \& M-L. Wong (Eds.), Biology of Depression. From Novel Insights to Therapeutic Strategies. Weinheim: Wiley-VCH.

Haglund, M. E. M., Nestadt, P. S., Cooper, N. S., Southwick, S. M., \& Charney, D. S. (2007). Psychobiological mechanisms of resilience: relevance to prevention and 
treatment of stress-related psychopathology. Development and Psychopathology, 19(3), 889-920.

Hajszan, T., Dow, A., Warner-Schmidt, J. L., Szigeti-Buck, K., Sallam, N. L., Parducz, A., Leranth, C., \& Duman, R. S. (2009). Remodeling of hippocampal spine synapses in the rat learned helplessness model of depression. Biological Psychiatry, 65(5), 392-400.

Herdegen, T., Kovary, K., Buhl, A., Bravo, R., Zimmermann, M., \& Gass, P. (1995). Basal expression of the inducible transcription factors c-Jun, JunB, JunD, c-Fos, FosB, and Krox-24 in the adult rat brain. Journal of Comparative Neurology, 354(1), 39-56.

Herdegen, T., \& Leah, J. D. (1998). Inducible and constitutive transcription factors in the mammalian nervous system: control of gene expression by Jun, Fos and Krox, and CREB/ATF proteins. Brain Research Reviews, 28(3), 370-490.

Herrera, D. G., \& Robertson, H. A. (1996). Activation of $c$-fos in the brain. Progress in Neurobiology, 50(2-3), 83-107.

Howard, R. W. (1995). Learning and memory: major ideas, principles, issues, and applications. Praeger Publishers: Westport.

Huang, R-P., Liu, C., Fan, Y., Mercola, D., \& Adamson, E. D. (1995). Egr-1 negatively regulates human tumor cell growth via the DNA-binding domain. Cancer Research, 55(21), 5054-5062. 
Huang, Y., Cheng, C., Hong, C., \& Tsai, S. (2004). Expression of c-Fos-like immunoreactivity in the brain of mice with learned helplessness. Neuroscience Letters, 363(3), 280-283.

Hunziker, M. H. L. (1981). Um estudo sobre a incontrolabilidade. Considerações metodológicas, uma análise experimental. Tese de Doutorado, Universidade de São Paulo, São Paulo.

Hunziker, M. H. L. (1997). Desamparo aprendido e a análise funcional da depressão. Em: Roberto A. Banaco (Org.) Sobre Comportamento e Cognição - volume 1. São Paulo: Editora da Sociedade Brasileira de Psiquiatria e Medicina Comportamental, cap. 20, 141-149.

Hunziker, M. H. L. (2003). Desamparo aprendido. Tese de Livre-Docência, Universidade de São Paulo: São Paulo.

Hunziker, M. H. L. (2005). O desamparo aprendido revisitado: estudos com animais. Psicologia: Teoria e Pesquisa, 21(2), 131-139.

Hunziker, M. H. L., \& Gehm, T. P. (no prelo). Uma nova interpretação sobre o desamparo aprendido. Sobre Comportamento e Cognição.

Hunziker, M. H. L., \& Santos, C. V. (2007). Learned helplessness: Effects of response requirement and interval between treatment and testing. Behavioural Processes, 76(3), 183-191.

Ikegaya, Y., Saito, H., \& Abe, K. (1995). High-frequency stimulation of the basolateral amygdala facilitates the induction of long-term potentiation in the dentate gyrus in vivo. Neuroscience Research, 22(2), 203-207. 
Ishikawa, A., \& Nakamura, S. (2003). Convergence and interaction of hippocampal and amygdalar projections within the prefrontal cortex in the rat. The Journal of Neuroscience, 23(31), 9987-9995.

Ishikawa, A., \& Nakamura, S. (2006). Ventral hippocampal neurons project axons simultaneously to the medial prefrontal córtex and amygdala in the rat. Journal of Neurophysiology, 96(4), 2134-2138.

Izquierdo, I., \& Cammarota, M. (2004). Zif and the survival of memory. Science, 304(5672), 829-830.

Jackson, R. L., Maier, S. F., \& Coon, D. J. (1979). Long-term analgesic effects of inescapable shock and learned helplessness. Science, 206(4414), 91-94.

Jans, J. E., \& Catania, A. C. (1980). Short-term remembering of discriminative stimuli in pigeons. Journal of the Experimental Analysis of Behavior, 34(2), 177-183.

Jas, J., Almaguer, W., Frey, J. U., \& Bergado, J. (2000). Lesioning the fimbria-fornix impairs basolateral amygdala induced reinforcement of LTP in the dentate gyrus. Brain Research, 861(1), 186-189.

Jones, M. W., Errington, M. L., French, P. J., Fine, A., Bliss, T. V. P., Garel, S., Charnay, P., Bozon, B., Laroche, S., \& Davis, S. (2001). A requirement for the immediate early gene Zif268 in the expression of late LTP and long-term memories. Nature Neuroscience, 4(3), 289-296.

Jones, S. L., Nation, J. R., \& Massad, P. (1977). Immunization against learned helplessness in man. Journal of Abnormal Psychology, 86(1), 75-83. 
Jung, M. W., Baeg, E. H., Kim, M. J., Kim, Y. B., \& Kim, J. J. (2008). Plasticity and memory in the prefrontal cortex. Reviews in Neuroscience, 19(1), 29-46.

Kaczmarek, L. (2000). Gene expression in learning processes. Acta Neurobiologiae Experimentalis, 60(3), 419-424.

Kalueff, A. V., \& Tuohimaa, P. (2004). Experimental modeling of anxiety and depression. Acta Neurobiologiae Experimentalis, 64(4), 439-448.

Kandel, E. R., Schwartz, J. H., \& Jessell, T. M. (2000). Principles of Neural Science. New York: McGraw-Hill.

Kanter, J. W., Callaghan, G. M., Landes, S. J., Busch, A. M., \& Brown, K. R. (2004). Behavior analytic conceptualization and treatment of depression: Traditional models and recent advances. The Behavior Analyst Today, 5(3), 255-274.

Kavushansky, A., Vouimba, R. M., Cohen, H., \& Richter-Levin, G. (2006). Activity and plasticity in the CA1, the dentate gyrus, and the amygdala following controllable vs. uncontrollable water stress. Hippocampus, 16(1), 35-42.

Kim, J. J., \& Diamond, D. M. (2002). The stressed hippocampus, synaptic plasticity and lost memories. Nature Reviews Neuroscience, 3(6), 453-462.

Kim, J. J., Song, E. Y., \& Kosten, T. A. (2006). Stress effects in the hippocampus: synaptic plasticity and memory. Stress, 9(1), 1-11.

Kim, S. C., Jo, Y. S., Kim, I. H., Kim, H., \& Choi, J-S. (2010). Lack of medial prefrontal cortex activation underlies the immediate extinction deficit. The Journal of Neuroscience, 30(3), 832-837. 
Klein, D. C., \& Seligman, M. E. P. (1976). Reversal of performance deficits and perceptual deficits in learned helplessness and depression. Journal of Abnormal Psychology, 85(1), 11-26.

Knapska, E., \& Kaczmarek, L. (2004). A gene for neuronal plasticity in the mammalian brain: Zif268/Egr-1/NGFI-A/Krox-24/TIS8/ZENK? Progress in Neurobiology, 74(4), 183-211.

Koba, T., Kodama, Y., Shimizu, K., Nomura, S., Sugawara, M., Kobayashi, Y., \& Ogasawara, T. (2001). Persistent behavioural changes in rats following inescapable shock stress: a potential model of posttraumatic stress disorder. The World Journal of Biological Psychiatry, 2(1), 34-37.

Kovács, K. J. (2008). Measurement of immediate-early gene activation- $c$-fos and beyond. Journal of Neuroendocrinology, 20(6), 665-672.

Krukoff, T. L. (1998). c-fos expression as a marker of functional activity in the brain. Neuromethods, 33, 213-230.

Kubik, S., Miyashita, T., \& Guzowski, J. F. (2007). Using immediate-early genes to map hippocampal subregional functions. Learning and Memory, 14(11), 758-770.

Lanahan, A., \& Worley, P. (1998). Immediate-early genes and synaptic function. Neurobiology of Learning and Memory, 70(1-2), 37-43.

Lathe, R. (2001). Hormones and the hippocampus. Journal of Endocrinology, 169(2), 205-231. 
Liberzon, I., \& Martis, B. (2006). Neuroimaging studies of emotional responses in PTSD. Annals of the New York Academy of Sciences, 1071, 87-109.

Liberzon, I., \& Sripada, C. S. (2007). The functional neuroanatomy of PTSD: a critical review. Progress in Brain Research, 167, 151-169.

Likhtik, E., Pelletier, J. G., Paz, R., \& Paré, D. (2005). Prefrontal control of the amygdala. The Journal of Neuroscience, 25(32), 7429-7437.

Li, L., Carter, J., Gao, X., Whitehead, J., \& Tourtellotte, W. G. (2005). The neuroplasticity-associated arc gene is a direct transcriptional target of early growth response (Egr) transcription factors. Molecular and Cellular Biology, 25(23), 10286-10300.

Liu, C., Adamson, E., \& Mercola, D. (1996). Transcription factor Egr-1 suppresses the growth and transformation of human HT-1080 fibrosarcoma cells by induction of transforming growth factor beta 1. Proceedings of the National Academy of Sciences of the United States of America, 93(21), 11831-11836.

Louvart, H., Maccari, S., Ducrocq, F., Thomas, P., \& Darnaudéry, M. (2005). Long-term behavioural alterations in female rats after a single intense footshock followed by situational reminders. Psychoneuroendocrinology, 30(4), 316-324.

Lynch, M. A. (2004). Long-term potentiation and memory. Physiological Reviews, 84(1), 87-136.

Maier, S.F. (2001). Exposure to the stressor environment prevents the temporal dissipation of behavioral depression/learned helplessness. Biological Psychiatry, 49(9), 763-773. 
Maier, S. F., Coon, D. J., McDaniel, M. A., Jackson, R. L., \& Grau, J. (1979). The time course of learned helplessness, inactivity, and nociceptive deficits in rats. Learning and Motivation, 10, 467-487.

Maier, S. F., \& Seligman, M. E. P. (1976). Learned helplessness: theory and evidence. Journal of Experimental Psychology: General, 105, 3-46.

Maier, S. F., \& Watkins, L. R. (2005). Stressor controllability and learned helplessness: The roles of the dorsal raphe nucleus, serotonin, and corticotropin-releasing factor. Neuroscience and Biobehavioral Reviews, 29(4-5), 829-841.

Malberg, J. E. (2004). Implications of adult hippocampal neurogenesis in antidepressant action. Journal of Psychiatry and Neuroscience, 29(3), 196-205.

Malkani, S., \& Rosen, J. B. (2000). Specific induction of early growth response gene 1 in the lateral nucleus of the amygdala following contextual fear conditioning in rats. Neuroscience, 97(4), 693-702.

Maren, S. (2003). What the amygdala does and doesn't do in aversive learning. Learning and Memory, 10(5), $306-308$.

Maroun, M., \& Richter-Levin, G. (2003). Exposure to acute stress blocks the induction of long-term potentiation of the amygdala-prefrontal cortex pathway in vivo. The Journal of Neuroscience, 23(11), 4406-4409.

McEwen, B. S. (2005). Stressed or stressed out: what is the difference? Journal of Psychiatry and Neuroscience, 30(5), 315-318. 
McKinney, W. T. (1984). Animal models of depression: an overview. Psychiatric Developments, 2(2), 77-96.

Mestre, M. B. A. (1996). O desamparo aprendido, em ratos adultos, como função de experiências aversivas incontroláveis na infância. Dissertação de Mestrado, Universidade de São Paulo, São Paulo.

Milad, M. R., Rauch, S. L., Pitman, R. K., \& Quirk, G. J. (2006). Fear extinction in rats: implications for human brain imaging and anxiety disorders. Biological Psychology, 73(1), 61-71.

Miller, M., \& McEwen, B. S. (2006). Establishing an agenda for translational research on PTSD. Annals of the New York Academy of Sciences, 1071(1), 294-312.

Morris, E. K., \& Smith, N. G. (2004). On the origin and preservation of cumulative record in its struggle for life as a favored term. Journal of the Experimental Analysis of Behavior, 82(3), 357-373.

Moye, T. B., Hyson, R. L., Grau, J. W., \& Maier, S. F. (1983). Immunization of opioid analgesia: Effects of prior escapable shock on subsequent shock-induced antinociception. Learning and Motivation, 14, 238-251.

Muigg, P., Hetzenauer, A., Hauer, G., Hauschild, M., Gaburro, S., Frank, E., Landgraf, R., \& Singewald, N. (2008). Impaired extinction of learned fear in rats selectively bred for high anxiety-evidence of altered neuronal processing in prefrontal-amygdala pathways. The European Journal of Neuroscience, 28(11), 2299-2309. 
Nestler, E. J., Gould, E., Manji, H., Buncan, M., Duman, R. S., Gershenfeld, H. K., Hen, R., Koester, S., Lederhendler, I., Meaney, M., Robbins, T., Winsky, L., \& Zalcman, S. (2002). Preclinical models: status of basic research in depression. Biological Psychiatry, 52(6), 503-528.

Neves, G., Cooke, S. F., \& Bliss, T. V. P. (2008). Synaptic plasticity, memory and the hippocampus: a neural network approach to causality. Nature Reviews Neuroscience, $9(1), 65-75$.

O’Donnell, M. L., Creamer, M., \& Pattison, P. (2004). Posttraumatic stress disorder and depression following trauma: Understanding comorbidity. American Journal of Psychiatry, 161(8), 1390-1396.

Overmier, J. B. (2002). On learned helplessness. Integrative Physiological and Behavioral Science, 37(1), 4-8.

Overmier, J. B., \& Leaf, R. C. (1965). Effects of discriminative Pavlovian fear conditioning upon previously or subsequently acquired avoidance responding. Journal of Comparative and Physiological Psychology, 60(2), 213-217.

Overmier, J. B., \& Seligman, M. E. P. (1967). Effects of inescapable shock upon subsequent escape and avoidance learning. Journal of Comparative and Physiological Psychology, 63(1), 23-33.

Paizanis, E., Hamon, M., \& Lanfumey, L. (2007). Hippocampal neurogenesis, depressive disorders, and antidepressant therapy. Neural Plasticity, ID73754.

Paré, D. (2003). Role of basolateral amígdala in memory consolidation. Progress in Neurobiology, 70(5), 409-420. 
Paxinos, G., \& Watson, C. (2005). The rat brain: in stereotaxic coordinates (5a ed.), Elsevier Academic Press: Amsterdam.

Perez-Castillo, A., Pipaón, C., García, I., \& Alemany, S. (1993). NGFI-A gene expression is necessary for T lymphocyte proliferation. The Journal of Biological Chemistry, 268(26), 19445-19450.

Peterson, C., Maier, S. F., \& Seligman, M. E. P. (1993). Learned Helplessness: A Theory for Age of Personal Control. New York: Oxford University Press.

Pinto, A. R. (2001). Medo: Algumas considerações numa ótica behaviorista radical. Lato e Sensu, 2(3), 14-15.

Pittenger, C., \& Duman, R. S. (2008). Stress, depression, and neuroplasticity: A convergence of mechanisms. Neuropsychopharmacology, 33(1), 88-109.

Poirier, R., Cheval, H., Mailhes, C., Garel, S., Charnay, P., Davis, S., \& Laroche, S. (2008). Distinct functions of Egr gene family members in cognitive processes. Frontiers in Neuroscience, 2(1), 47-55.

Quirk, G. J., Garcia, R., \& González-Lima, F. (2006). Prefrontal mechanisms in extinction of conditioned fear. Biological Psychiatry, 60(4), 337-343.

Racagni, G., \& Popoli, M. (2008). Cellular and molecular mechanisms in the long-term action of antidepressants. Dialogues in Clinical Neuroscience, 10(14), 385-400.

Ramaswamy, S., Madaan, V., Qadri, F., Heaney, C. J., North, T. C., Padala, P. R., Sattar, S. P., \& Petty, F. (2005). A primary care perspective of posttraumatic 
stress disorder for the Department of Veterans Affairs. Primary Care Companion to the Journal of Clinical Psychiatry, 7(4), 180-187.

Ronan, P. J., Steciuk, M., Kramer, G. L, Kram, M., \& Petty, F. (2000). Increased septal 5-HIAA efflux in rats that do not develop learned helplessness after inescapable stress. Journal of Neuroscience Research, 61(1), 101-106.

Rosen, J. B. (2004). The neurobiology of conditioned and unconditioned fear: a neurobehavioral system analysis of the amygdala. Behavioral and Cognitive Neuroscience Reviews, 3(1), 23-41.

Ryan, B. K., Vollmayr, B., Klyubin, I., Gass, P., \& Rowan, M. J. (2009). Persistent inhibition of hippocampal long-term potentiation in vivo by learned helplessness stress. Hippocampus, [Epub ahead of print].

Sala, M., Perez, J., Soloff, P., Ucelli di Nemi, S., Caverzasi, E., Soares, J.C., \& Brambilla, P. (2004). Stress and hippocampal abnormalities in psychiatric disorders. European Neuropsychopharmacology, 14(5), 393-405.

Saray, A., \& Hen, R. (2007). Adult hippocampal neurogenesis in depression. Nature Neuroscience, 10(9), 1110-1115.

Seligman, M. E. P. (1975). Helplessness: On depression, development, and death. Freeman, San Francisco.

Seligman, M. E. P., \& Maier, S. F. (1967). Failure to escape traumatic shock. Journal of Experimental Psychology, 74(1), 1-9. 
Seligman, M. E. P., Rosellini, R. A., \& Kozak, M. J. (1975). Learned helplessness in the rat: time course, immunization, and reversibility. Journal of Comparative and Physiological Psychology, 88(2), 542-547.

Selye, H. (1975). Confusion and controversy in the stress field. Journal of Human Stress, 1(2), 37-44.

Sheline, Y. I. (2003). Neuroimaging studies of mood disorder effects on the brain. Biological Psychiatry, 54(3), 338-352.

Sheng, M., \& Greenberg, M. F. (1990). The regulation and function of $c$-fos and other immediate early genes in the nervous system. Neuron, 4(4), 477-485.

Sherman, A. D., Allers, G. L., Petty, F., \& Henn, F. A. (1979). A neuropharmacologically-relevant animal model of depression. Neuropharmacology, 18(11), 891-893.

Sherman, A. D., Sacquitne, J. L., \& Petty, F. (1982). Specificity of the learned helplessness model of depression. Pharmacology Biochemistry and Behavior, $16(3), 449-454$.

Shin, L. M., Rauch, S. L., \& Pitman, R. K. (2006). Amygdala, medial prefrontal cortex, and hippocampal function in PTSD. Annals of the New York Academy of Sciences, 1071, 67-79.

Shors, T. J., Foy, M. R., Levine, S., \& Thompson, R. F. (1990). Unpredictable and uncontrollable stress impairs neuronal plasticity in the rat hippocampus. Brain Research Bulletin, 24(5), 663-667. 
Shors, T. J., \& Matzel, L. D. (1997). Long-term potentiation: What's learning got to do with it? Behavioral and Brain Sciences, 20(4), 597-655.

Sita, L. V., \& Bittencourt, J. C. (2007). Imunoistoquímica. In J. C. Bittencourt, \& C. F. Elias (Orgs.), Métodos em neurociência. São Paulo: Roca.

Skinner, B. F. (1975). The steep and thorny way to a science of behavior. American Psychologist, 30(1), 42-49.

Skinner, B. F. (1987). Whatever happened to Psychology as the Science of Behavior? American Psychologist, 42(8), 780-786.

Skinner, B. F. (1990). Can Psychology be a Science of Mind? American Psychologist, 45(11), 1206-1210.

Spencer, R. L., \& Bland, S. T. (2007). Hippocampal neurons. In G. Fink (Ed.), Encyclopedia of Stress, 2nd Ed., v. 2, 311-320. Oxford: Academic Press.

Squire, L. R. (2009). Memory and brain systems: 1969-2009. The Journal of Neuroscience, 29(41), 12711-12716.

Staddon, J. E. R. (2003). Adaptive behavior and learning. New York: Cambridge University Press. Disponível em: http://psychweb.psych.duke.edu/department/jers/abl/TableC.htm, Acesso em: 23 jan. 2010.

Steciuk, M., Kram, M., Kramer, G. L., \& Petty, F. (1999). Decrease in stress-induced cFos-like immunoreactivity in the lateral septal nucleus of learned helpless rats. Brain Research, 822(1-2), 256-259. 
Takahashi, L. K., Nakashima, B. R., Hong, H., \& Watanabe, K. (2005). The smell of danger: a behavioral and neural analysis of predator odor-induced fear. Neuroscience and Biobehavioral Reviews, 29(8), 1157-1167.

Thiel, G., \& Cibelli, G. (2002). Regulation of life and death by the zinc finger transcription factor Egr-1. Journal of Cellular Physiology, 193(3), 287-292.

Thiriet, N., Zwiller, J., \& Ali, S. F. (2001). Induction of the immediate early genes egr-1 and $c$-fos by methamphetamine in mouse brain. Brain Research, 919(1), 31-40.

Tischmeyer, W., \& Grimm, R. (1999). Activation of immediate early genes and memory formation. Cellular and Molecular Life Sciences, 55(4), 564-574.

Vaidya, V. A., \& Duman, R. S. (2001). Depression - emerging insights from neurobiology. British Medical Bulletin, 57, 61-79.

Van der Kolk, B. (1987). The drug treatment of post-traumatic stress disorder. Journal of Affective Disorders, 13(2), 203-213.

Van der Kolk, B., Greenberg, M., Boyd, H., \& Krystal, J. (1985). Inescapable shock, neurotransmitters, and addiction to trauma: Toward a psychobiology of posttraumatic stress. Biological Psychiatry, 20(3), 314-325.

Vanderwolf, C. H. (2007). The evolving brain: the mind and the neural control of behavior. New York: Springer.

Vollmayr, B., \& Henn, F. (2001). Learned helplessness in the rat: improvements in validity and reliability. Brain Research, Brain Research Protocols, 8(1), 1-7. 
Vollmayr, B., Mahlstedt, M. M., \& Henn, F. A. (2007). Neurogenesis and depression: what animal models tell us about the link. European Archives of Psychiatry and Clinical Neuroscience, 257(5), 300-303.

Vollmayr, B., Simonis, C., Weber, S., Glass, P., \& Henn, F. (2003). Reduced cell proliferation in the dentate gyrus is not correlated with the development of learned helplessness. Biological Psychiatry, 54(10), 1035-1040.

Walker, R. A. (2006). Quantification of immunohistochemistry - issues concerning methods, utility and semiquantitative assessment I. Histopathology, 49(4), 406410.

Wang, Z., Neylan, T. C., Mueller, S. G., Lenoci, M., Truran, D., Marmar, C. R., Weiner, M. W., \& Schuff, N. (2010). Magnetic resonance imaging of hippocampal subfields in posttraumatic stress disorder. Archives of General Psychiatry, 67(3), 296-303.

Warner-Schmidt, J. L., \& Duman, R. S. (2006). Hippocampal neurogenesis: opposing effects of stress and antidepressant treatment. Hippocampus, 16(3), 239-249.

Weiss, J. M., Glazer, H. I., Pohorecky, L. A., Brick, J., \& Miller, N. E. (1975). Effects of chronic exposure to stressors on avoidance escape behavior and brain norepinephrine. Psychosomatic Medicine, 37(6), 523-534.

Wessa, M., \& Flor, H. (2007). Failure of extinction of fear responses in posttraumatic stress disorder: Evidence from second-order conditioning. The American Journal of Psychiatry, 164(11), 1684-1692. 
Willner, P. (1984). The validity of animal models of depression. Psychopharmacology, 83(1), 1-16.

Willner, P. (1985). Depression: A Psychobiological Synthesis. New York: Wiley.

Willner, P. (1991a). Behavioural Models in Psychopharmacology: Theoretical, Industrial, and Clinical perspectives. Cambridge: Cambridge University Press.

Willner, P. (1991b). Models of Depression. In P. Willner (Ed.), Behavioural Models in Psychopharmacology: Theoretical, Industrial, and Clinical perspectives. Cambridge: Cambridge University Press.

Willner, P., \& Mitchell, P. J. (2002). The validity of animal models of predisposition to depression. Behavioural Pharmacology, 13(3), 169-188.

Wiltgen, B. J., Brown, R. A. M., Talton, L. E., \& Silva, A. J. (2004). New circuits for old memories: the role of the neocortex in consolidation. Neuron, 44(1), 101108.

Wisden, W., Errington, M. L., Williams, S., Dunnett, S. B., Waters, C., Hitchcock, D., Evan, G., Bliss, T. V., \& Hunt, S. P. (1990). Differential expression of immediate early genes in the hippocampus and spinal cord. Neuron, 4(4), 603614.

Wong, M-L., \& Licinio, J. (2001). Research and treatment approaches to depression. Nature Reviews, 2(5), 343-351. 
Wong, M-L., \& Licinio, J. (2004). From monoamines to genomic targets: a paradigm shift for drug discovery in depression. Nature Reviews Drug Discovery, 3(2), $136-151$.

Yehuda, R., \& Antelman, S. M. (1993). Criteria for rationally evaluating animal models of posttraumatic stress disorder. Biological Psychiatry, 33(7), 479-486.

Yehuda, R., \& LeDoux, J. (2007). Response variation following trauma: a translational neuroscience approach to understanding PTSD. Neuron, 56(1), 19-32.

Zangenehpour, S., \& Chaudhuri, A. (2002). Differencial induction and decay curves of c-fos and zif268 revealed through dual activity maps. Brain Research. Molecular Brain Research, 109(1-2), 221-225. 


\section{APÊNDICE}


Tabela 1 - Latências médias (s) das tentativas dos grupos Ingênuo (ING) e Desamparado (DES) e os resultados da análise de variância de duas vias para medidas repetidas (two-way ANOVA RM) com teste post-hoc de Bonferroni.

\begin{tabular}{|c|c|c|c|c|c|c|}
\hline Tentativas & ING & DES & Diferença & $t$ & Valor de $\mathrm{P}$ & Resumo \\
\hline 1 & 2,840 & 5,095 & 2,255 & 1,510 & $P>0.05$ & ns \\
\hline 2 & 4,850 & 6,446 & 1,596 & 1,069 & $P>0.05$ & ns \\
\hline 3 & 5,176 & 7,826 & 2,651 & 1,775 & $P>0.05$ & ns \\
\hline 4 & 4,833 & 8,874 & 4,041 & 2,706 & $P>0.05$ & ns \\
\hline 5 & 4,950 & 6,405 & 1,455 & 0,9742 & $P>0.05$ & ns \\
\hline 6 & 5,783 & 10,020 & 4,235 & 2,835 & $P>0.05$ & ns \\
\hline 7 & 5,541 & 9,988 & 4,446 & 2,977 & $P>0.05$ & ns \\
\hline 8 & 4,631 & 9,984 & 5,352 & 3,584 & $P<0.05$ & * \\
\hline 9 & 4,817 & 8,885 & 4,068 & 2,724 & $P>0.05$ & ns \\
\hline 10 & 5,624 & 7,854 & 2,229 & 1,493 & $P>0.05$ & ns \\
\hline 11 & 3,233 & 7,809 & 4,576 & 3,064 & $P>0.05$ & ns \\
\hline 12 & 3,434 & 8,855 & 5,421 & 3,630 & $P<0.01$ & ** \\
\hline 13 & 3,454 & 10,000 & 6,549 & 4,385 & $P<0.001$ & $\star \star \star *$ \\
\hline 14 & 3,427 & 8,666 & 5,239 & 3,508 & $P<0.05$ & * \\
\hline 15 & 2,713 & 10,000 & 7,291 & 4,882 & $P<0.001$ & $* \star \star$ \\
\hline 16 & 3,679 & 9,989 & 6,310 & 4,225 & $P<0.001$ & $* \star *$ \\
\hline 17 & 3,201 & 10,020 & 6,815 & 4,563 & $P<0.001$ & 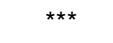 \\
\hline 18 & 1,909 & 9,996 & 8,088 & 5,415 & $P<0.001$ & $\star \star \star *$ \\
\hline 19 & 3,599 & 7,331 & 3,733 & 2,499 & $P>0.05$ & ns \\
\hline 20 & 4,456 & 10,030 & 5,576 & 3,733 & $P<0.01$ & ** \\
\hline 21 & 1,881 & 8,735 & 6,854 & 4,589 & $P<0.001$ & $* * *$ \\
\hline 22 & 3,374 & 9,350 & 5,976 & 4,001 & $P<0.01$ & ** \\
\hline 23 & 3,711 & 8,925 & 5,214 & 3,491 & $P<0.05$ & * \\
\hline 24 & 2,697 & 8,924 & 6,227 & 4,169 & $P<0.01$ & ** \\
\hline 25 & 2,761 & 10,000 & 7,240 & 4,848 & $P<0.001$ & $* * *$ \\
\hline 26 & 1,867 & 9,994 & 8,127 & 5,441 & $P<0.001$ & $* * *$ \\
\hline 27 & 2,354 & 9,998 & 7,643 & 5,118 & $P<0.001$ & $* * *$ \\
\hline 28 & 1,787 & 8,014 & 6,227 & 4,169 & $P<0.01$ & ** \\
\hline 29 & 3,296 & 9,085 & 5,789 & 3,876 & $P<0.01$ & ** \\
\hline 30 & 3,037 & 10,010 & 6,974 & 4,670 & $P<0.001$ & *** \\
\hline
\end{tabular}


Tabela 2 - Latências médias (s) das tentativas dos grupos Não Desamparado (NDE) e Desamparado (DES) e os resultados da análise de variância de duas vias para medidas repetidas (two-way ANOVA RM) com teste post-hoc de Bonferroni.

\begin{tabular}{|c|c|c|c|c|c|c|}
\hline Tentativas & NDE & DES & Diferença & $\mathrm{t}$ & Valor de $\mathrm{P}$ & Resumo \\
\hline 1 & 5,738 & 5,095 & $-0,643$ & 0,413 & $P>0.05$ & ns \\
\hline 2 & 2,170 & 6,446 & 4,276 & 2,744 & $P>0.05$ & ns \\
\hline 3 & 6,153 & 7,826 & 1,673 & 1,073 & $P>0.05$ & ns \\
\hline 4 & 5,858 & 8,874 & 3,015 & 1,935 & $P>0.05$ & ns \\
\hline 5 & 4,165 & 6,405 & 2,240 & 1,437 & $P>0.05$ & ns \\
\hline 6 & 6,763 & 10,020 & 3,254 & 2,088 & $P>0.05$ & ns \\
\hline 7 & 7,078 & 9,988 & 2,909 & 1,867 & $P>0.05$ & ns \\
\hline 8 & 5,355 & 9,984 & 4,629 & 2,970 & $P>0.05$ & ns \\
\hline 9 & 6,098 & 8,885 & 2,787 & 1,788 & $P>0.05$ & ns \\
\hline 10 & 3,672 & 7,854 & 4,182 & 2,684 & $P>0.05$ & ns \\
\hline 11 & 4,715 & 7,809 & 3,094 & 1,985 & $P>0.05$ & ns \\
\hline 12 & 5,858 & 8,855 & 2,997 & 1,923 & $P>0.05$ & ns \\
\hline 13 & 6,628 & 10,000 & 3,375 & 2,166 & $P>0.05$ & ns \\
\hline 14 & 3,220 & 8,666 & 5,446 & 3,495 & $P<0.05$ & * \\
\hline 15 & 5,108 & 10,000 & 4,895 & 3,141 & $P>0.05$ & ns \\
\hline 16 & 5,662 & 9,989 & 4,327 & 2,777 & $P>0.05$ & ns \\
\hline 17 & 3,928 & 10,020 & 6,088 & 3,906 & $P<0.01$ & ** \\
\hline 18 & 4,968 & 9,996 & 5,028 & 3,226 & $P<0.05$ & * \\
\hline 19 & 3,890 & 7,331 & 3,441 & 2,208 & $P>0.05$ & ns \\
\hline 20 & 6,117 & 10,030 & 3,915 & 2,512 & $P>0.05$ & ns \\
\hline 21 & 2,455 & 8,735 & 6,280 & 4,030 & $P<0.01$ & ** \\
\hline 22 & 5,950 & 9,350 & 3,400 & 2,182 & $P>0.05$ & ns \\
\hline 23 & 3,315 & 8,925 & 5,610 & 3,600 & $P<0.05$ & * \\
\hline 24 & 2,910 & 8,924 & 6,014 & 3,859 & $P<0.01$ & ** \\
\hline 25 & 4,578 & 10,000 & 5,423 & 3,480 & $P<0.05$ & * \\
\hline 26 & 4,877 & 9,994 & 5,117 & 3,283 & $P<0.05$ & * \\
\hline 27 & 5,457 & 9,998 & 4,541 & 2,914 & $P>0.05$ & ns \\
\hline 28 & 2,567 & 8,014 & 5,447 & 3,495 & $P<0.05$ & * \\
\hline 29 & 3,682 & 9,085 & 5,403 & 3,467 & $P<0.05$ & * \\
\hline 30 & 2,708 & 10,010 & 7,303 & 4,686 & $P<0.001$ & $* * *$ \\
\hline
\end{tabular}


Tabela 3 - Latências médias (s) das tentativas dos grupos Ingênuo (ING) e Não Desamparado (NDE) e os resultados da análise de variância de duas vias para medidas repetidas (two-way ANOVA RM) com teste post-hoc de Bonferroni.

\begin{tabular}{|c|c|c|c|c|c|c|}
\hline Tentativas & ING & NDE & Diferença & $\mathrm{t}$ & Valor de $\mathrm{P}$ & Resumo \\
\hline 1 & 2,840 & 5,738 & 2,898 & 1,805 & $P>0.05$ & ns \\
\hline 2 & 4,850 & 2,170 & $-2,680$ & 1,669 & $P>0.05$ & ns \\
\hline 3 & 5,176 & 6,153 & 0,978 & 0,6089 & $P>0.05$ & ns \\
\hline 4 & 4,833 & 5,858 & 1,025 & 0,6388 & $P>0.05$ & ns \\
\hline 5 & 4,950 & 4,165 & $-0,785$ & 0,4890 & $P>0.05$ & ns \\
\hline 6 & 5,783 & 6,763 & 0,980 & 0,6107 & $P>0.05$ & ns \\
\hline 7 & 5,541 & 7,078 & 1,537 & 0,9573 & $P>0.05$ & ns \\
\hline 8 & 4,631 & 5,355 & 0,724 & 0,4507 & $P>0.05$ & ns \\
\hline 9 & 4,817 & 6,098 & 1,281 & 0,7980 & $P>0.05$ & ns \\
\hline 10 & 5,624 & 3,672 & $-1,953$ & 1,216 & $P>0.05$ & ns \\
\hline 11 & 3,233 & 4,715 & 1,482 & 0,9232 & $P>0.05$ & ns \\
\hline 12 & 3,434 & 5,858 & 2,424 & 1,510 & $P>0.05$ & ns \\
\hline 13 & 3,454 & 6,628 & 3,174 & 1,977 & $P>0.05$ & ns \\
\hline 14 & 3,427 & 3,220 & $-0,207$ & 0,1290 & $P>0.05$ & ns \\
\hline 15 & 2,713 & 5,108 & 2,395 & 1,492 & $P>0.05$ & ns \\
\hline 16 & 3,679 & 5,662 & 1,983 & 1,235 & $P>0.05$ & ns \\
\hline 17 & 3,201 & 3,928 & 0,727 & 0,4528 & $P>0.05$ & ns \\
\hline 18 & 1,909 & 4,968 & 3,060 & 1,906 & $P>0.05$ & ns \\
\hline 19 & 3,599 & 3,890 & 0,291 & 0,1815 & $P>0.05$ & ns \\
\hline 20 & 4,456 & 6,117 & 1,661 & 1,035 & $P>0.05$ & ns \\
\hline 21 & 1,881 & 2,455 & 0,574 & 0,3573 & $P>0.05$ & ns \\
\hline 22 & 3,374 & 5,950 & 2,576 & 1,604 & $P>0.05$ & ns \\
\hline 23 & 3,711 & 3,315 & $-0,396$ & 0,2469 & $P>0.05$ & ns \\
\hline 24 & 2,697 & 2,910 & 0,213 & 0,1326 & $P>0.05$ & ns \\
\hline 25 & 2,761 & 4,578 & 1,817 & 1,132 & $P>0.05$ & ns \\
\hline 26 & 1,867 & 4,877 & 3,010 & 1,875 & $P>0.05$ & ns \\
\hline 27 & 2,354 & 5,457 & 3,102 & 1,932 & $P>0.05$ & ns \\
\hline 28 & 1,787 & 2,567 & 0,779 & 0,4856 & $P>0.05$ & ns \\
\hline 29 & 3,296 & 3,682 & 0,386 & 0,2404 & $P>0.05$ & ns \\
\hline 30 & 3,037 & 2,708 & $-0,329$ & 0,2048 & $P>0.05$ & ns \\
\hline
\end{tabular}


Quadro II - Magnitude da correlação entre os valores de densidade de núcleos imunorreativos das estruturas, estimada por meio do coeficiente de correlação (r) de Pearson.

\begin{tabular}{|c|c|c|c|c|c|c|c|c|c|c|c|c|c|c|}
\hline & $\begin{array}{l}\text { ABL } \\
\text { Fos }\end{array}$ & $\begin{array}{l}\text { ACe } \\
\text { Fos }\end{array}$ & $\begin{array}{l}\text { CA1 } \\
\text { Fos }\end{array}$ & $\begin{array}{l}\text { CA3 } \\
\text { Fos }\end{array}$ & $\begin{array}{c}\text { CPFm } \\
\text { Fos }\end{array}$ & $\begin{array}{l}\text { GD } \\
\text { Fos }\end{array}$ & $\begin{array}{l}\text { NSL } \\
\text { Fos }\end{array}$ & $\begin{array}{c}\text { ABL } \\
\text { Egr-1 }\end{array}$ & $\begin{array}{c}\text { ACe } \\
\text { Egr-1 }\end{array}$ & \begin{tabular}{|c|} 
CA1 \\
Egr-1
\end{tabular} & \begin{tabular}{|c} 
CA3 \\
Egr-1
\end{tabular} & $\begin{array}{l}m \\
1\end{array}$ & $\begin{array}{c}\text { GD } \\
\text { Egr-1 }\end{array}$ & $\begin{array}{l}\text { NSL } \\
\text { Egr-1 }\end{array}$ \\
\hline & & $\begin{array}{r}+818 \\
22 \\
\end{array}$ & $\begin{array}{r}6783 \\
387 \\
\end{array}$ & $\begin{array}{r}0,51891 \\
77 \\
\end{array}$ & $\begin{array}{l}8 \\
3 \\
\end{array}$ & $\begin{array}{r}1137 \\
59 \\
\end{array}$ & $\begin{array}{r}16 \\
1 \\
\end{array}$ & $\begin{array}{r}2328 \\
88 \\
\end{array}$ & $\begin{array}{r}6055 \\
71 \\
\end{array}$ & & $\begin{array}{r}3487 \\
14 \\
\end{array}$ & & $\begin{array}{r}32922 \\
88 \\
\end{array}$ & 8 \\
\hline $\begin{array}{l}\text { ACe } \\
\text { Fos }\end{array}$ & & & $\begin{array}{r}0,12706 \\
69 \\
\end{array}$ & $\begin{array}{r}0,55972 \\
7 \\
\end{array}$ & $\begin{array}{r}0,24671 \\
5 \\
\end{array}$ & \begin{tabular}{|r|}
0,42768 \\
14 \\
\end{tabular} & $\begin{array}{r}0,22200 \\
22 \\
\end{array}$ & $\begin{array}{r}0,36088 \\
4 \\
\end{array}$ & $\begin{array}{r}0,37304 \\
46 \\
\end{array}$ & $\begin{array}{r}0,01360 \\
657 \\
\end{array}$ & \begin{tabular}{|r|}
0,17365 \\
09 \\
\end{tabular} & $\begin{array}{r}1687 \\
143 \\
\end{array}$ & $\begin{array}{r}37545 \\
44 \\
\end{array}$ & $\begin{array}{r}26446 \\
13 \\
\end{array}$ \\
\hline $\begin{array}{l}\mathbf{C} \\
\mathbf{F}\end{array}$ & $\begin{array}{r}6783 \\
387 \\
\end{array}$ & $\begin{array}{r}2706 \\
69 \\
\end{array}$ & & $\begin{array}{r}0,03179 \\
947 \\
\end{array}$ & \begin{tabular}{|r|}
0,72533 \\
67 \\
\end{tabular} & $\begin{array}{r}0,09042 \\
175 \\
\end{array}$ & 0,22823 & $\begin{array}{r}0,37752 \\
53 \\
\end{array}$ & $\begin{array}{r}0,50598 \\
6 \\
\end{array}$ & \begin{tabular}{|r|}
0,20131 \\
76 \\
\end{tabular} & \begin{tabular}{|r|}
0,16443 \\
89 \\
\end{tabular} & $\begin{array}{r}0,37390 \\
66 \\
\end{array}$ & $\begin{array}{r}0,21404 \\
51 \\
\end{array}$ & $\begin{array}{r}1208 \\
44 \\
\end{array}$ \\
\hline$F$ & $\begin{array}{r}891 \\
77 \\
\end{array}$ & 7 & $\begin{array}{r}0,03179 \\
947 \\
\end{array}$ & & $\begin{array}{r}4113 \\
282 \\
\end{array}$ & $\begin{array}{r}0,41926 \\
94 \\
\end{array}$ & $\begin{array}{r}0,38405 \\
69 \\
\end{array}$ & $\begin{array}{r}0,25889 \\
37 \\
\end{array}$ & $\begin{array}{r}288 \\
39 \\
\end{array}$ & $\begin{array}{r}0,19880 \\
83 \\
\end{array}$ & $\begin{array}{r}0,14990 \\
72 \\
\end{array}$ & $\begin{array}{r}84 \\
3 \\
\end{array}$ & $\begin{array}{r}0,51671 \\
12 \\
\end{array}$ & $\begin{array}{r}0,27232 \\
41 \\
\end{array}$ \\
\hline $\mathbf{n}$ & $\begin{array}{r}68 \\
3 \\
\end{array}$ & 5 & $\begin{array}{r}0,7253 \\
367 \\
\end{array}$ & $\begin{array}{r}0,04113 \\
282 \\
\end{array}$ & & $\begin{array}{r}0,16926 \\
3 \\
\end{array}$ & $\begin{array}{r}80 \\
2 \\
\end{array}$ & $\begin{array}{r}0,31943 \\
35 \\
\end{array}$ & $\begin{array}{r}0,39485 \\
95 \\
\end{array}$ & $\begin{array}{r}0,02590 \\
654 \\
\end{array}$ & $\begin{array}{r}0,25154 \\
45 \\
\end{array}$ & $\begin{array}{r}0,59352 \\
09 \\
\end{array}$ & $\begin{array}{r}0,15649 \\
56 \\
\end{array}$ & $\begin{array}{r}7630 \\
04 \\
\end{array}$ \\
\hline $\begin{array}{l}\text { GD } \\
\text { Fos } \\
\end{array}$ & $\begin{array}{r}4137 \\
59 \\
\end{array}$ & $\begin{array}{r}2768 \\
14 \\
\end{array}$ & $\begin{array}{r}0,09042 \\
175 \\
\end{array}$ & $\begin{array}{r}11926 \\
94 \\
\end{array}$ & $\begin{array}{r}26 \\
3 \\
\end{array}$ & & $\begin{array}{r}0,11394 \\
2 \\
\end{array}$ & $\begin{array}{r}0,39282 \\
77 \\
\end{array}$ & $\begin{array}{r}36681 \\
03 \\
\end{array}$ & $\begin{array}{r}0,09283 \\
951 \\
\end{array}$ & $\begin{array}{r}0,28340 \\
48 \\
\end{array}$ & $\begin{array}{r}25524 \\
46 \\
\end{array}$ & $\begin{array}{r}24477 \\
14 \\
\end{array}$ & $\begin{array}{r}0,02142 \\
787 \\
\end{array}$ \\
\hline$N$ & & $\begin{array}{r}0,22200 \\
22 \\
\end{array}$ & 823 & \begin{tabular}{|r|}
0,38405 \\
69 \\
\end{tabular} & \begin{tabular}{|r|}
0,34880 \\
2 \\
\end{tabular} & & & $\begin{array}{r}59570 \\
571 \\
\end{array}$ & $\begin{array}{r}9995 \\
963 \\
\end{array}$ & \begin{tabular}{|r|}
0,15591 \\
97 \\
\end{tabular} & $\begin{array}{r}1024 \\
18 \\
\end{array}$ & $\begin{array}{r}0951 \\
88 \\
\end{array}$ & $\begin{array}{r}8008 \\
01 \\
\end{array}$ & \begin{tabular}{|r|}
0,71883 \\
26 \\
\end{tabular} \\
\hline \begin{tabular}{c||}
$A B L$ \\
Egr-1
\end{tabular} & $\begin{array}{r}42328 \\
88 \\
\end{array}$ & $\begin{array}{r}6088 \\
4 \\
\end{array}$ & $\begin{array}{r}0,37752 \\
53 \\
\end{array}$ & $\begin{array}{r}0,25889 \\
37 \\
\end{array}$ & $\begin{array}{r}0,31943 \\
35 \\
\end{array}$ & $\begin{array}{r}0,39282 \\
77 \\
\end{array}$ & $\begin{array}{r}0,09570 \\
571 \\
\end{array}$ & & $\begin{array}{r}0,90168 \\
77 \\
\end{array}$ & $\begin{array}{r}0,00524 \\
4546 \\
\end{array}$ & $\begin{array}{r}0,61699 \\
05 \\
\end{array}$ & $\begin{array}{r}0,08432 \\
787 \\
\end{array}$ & $\begin{array}{r}0,32113 \\
96 \\
\end{array}$ & $\begin{array}{r}0,02190 \\
609 \\
\end{array}$ \\
\hline \begin{tabular}{c||} 
ACe \\
Egr-1
\end{tabular} & $\begin{array}{r}46055 \\
71 \\
\end{array}$ & $\begin{array}{r}0,37304 \\
46 \\
\end{array}$ & $\begin{array}{r}0,50598 \\
6 \\
\end{array}$ & $\begin{array}{r}0,31288 \\
39 \\
\end{array}$ & $\begin{array}{r}0,39485 \\
95 \\
\end{array}$ & $\begin{array}{r}0,36681 \\
03 \\
\end{array}$ & $\begin{array}{r}0,09995 \\
963 \\
\end{array}$ & $\begin{array}{r}0,9016 \\
877 \\
\end{array}$ & & $\begin{array}{r}0,04323 \\
723 \\
\end{array}$ & \begin{tabular}{|r|}
0,56205 \\
12 \\
\end{tabular} & $\begin{array}{r}0,05152 \\
806 \\
\end{array}$ & $\begin{array}{r}0,36104 \\
46 \\
\end{array}$ & $\begin{array}{r}0,09842 \\
902 \\
\end{array}$ \\
\hline \begin{tabular}{c||} 
CA1 \\
Egr-1
\end{tabular} & $\begin{array}{l}0879 \\
4822 \\
\end{array}$ & $\begin{array}{r}0,01360 \\
657 \\
\end{array}$ & $\begin{array}{r}0,20131 \\
76 \\
\end{array}$ & \begin{tabular}{|r|}
0,19880 \\
83 \\
\end{tabular} & \begin{tabular}{|r|}
0,02590 \\
654 \\
\end{tabular} & $\begin{array}{r}0,09283 \\
951 \\
\end{array}$ & \begin{tabular}{|r|}
0,15591 \\
97 \\
\end{tabular} & $\begin{array}{r}0,00524 \\
4546 \\
\end{array}$ & $\begin{array}{r}0,04323 \\
723 \\
\end{array}$ & & $\begin{array}{r}0,36406 \\
78 \\
\end{array}$ & $\begin{array}{r}0,09033 \\
202 \\
\end{array}$ & \begin{tabular}{|r|}
0,05488 \\
762 \\
\end{tabular} & \begin{tabular}{|r|}
0,12179 \\
89 \\
\end{tabular} \\
\hline $\begin{array}{c}\text { CA3 } \\
\text { Egr-1 }\end{array}$ & $\begin{array}{r}23487 \\
14 \\
\end{array}$ & $\begin{array}{r}0,17365 \\
09 \\
\end{array}$ & $\begin{array}{r}0,16443 \\
89 \\
\end{array}$ & $\begin{array}{r}0,14990 \\
72 \\
\end{array}$ & $\begin{array}{r}0,25154 \\
45 \\
\end{array}$ & $\begin{array}{r}0,28340 \\
48 \\
\end{array}$ & $\begin{array}{r}0,11024 \\
18 \\
\end{array}$ & $\begin{array}{r}0,6169 \\
905 \\
\end{array}$ & $\begin{array}{r}0,56205 \\
12 \\
\end{array}$ & $\begin{array}{r}0,36406 \\
78 \\
\end{array}$ & & $\begin{array}{r}0,11831 \\
77 \\
\end{array}$ & $\begin{array}{r}3375 \\
36 \\
\end{array}$ & $\begin{array}{r}0,02576 \\
173 \\
\end{array}$ \\
\hline $\mathrm{Fm}$ & $\begin{array}{l}0268 \\
0264 \\
\end{array}$ & $\begin{array}{r}1687 \\
143 \\
\end{array}$ & $\begin{array}{r}0,37390 \\
66 \\
\end{array}$ & $\begin{array}{r}0,10684 \\
3 \\
\end{array}$ & \begin{tabular}{|r|}
0,59352 \\
09 \\
\end{tabular} & $\begin{array}{r}0,25524 \\
46 \\
\end{array}$ & \begin{tabular}{|r|}
0,30951 \\
88 \\
\end{tabular} & $\begin{array}{r}0,08432 \\
787 \\
\end{array}$ & $\begin{array}{r}0,05152 \\
806 \\
\end{array}$ & $\begin{array}{r}0,09033 \\
202 \\
\end{array}$ & \begin{tabular}{|r|}
0,11831 \\
77 \\
\end{tabular} & & $\begin{array}{r}0,10428 \\
75 \\
\end{array}$ & $\begin{array}{r}0,30369 \\
55 \\
\end{array}$ \\
\hline $\begin{array}{c}\text { GD } \\
\text { Egr-1 }\end{array}$ & $\begin{array}{r}32922 \\
88 \\
\end{array}$ & $\begin{array}{r}0,37545 \\
44 \\
\end{array}$ & $\begin{array}{r}0,21404 \\
51 \\
\end{array}$ & $\begin{array}{r}0,51671 \\
12 \\
\end{array}$ & \begin{tabular}{|r|}
0,15649 \\
56 \\
\end{tabular} & $\begin{array}{r}0,24477 \\
14 \\
\end{array}$ & \begin{tabular}{|r|}
0,6800 \\
801 \\
\end{tabular} & $\begin{array}{r}0,32113 \\
96 \\
\end{array}$ & $\begin{array}{r}0,36104 \\
46 \\
\end{array}$ & $\begin{array}{r}0,05488 \\
762 \\
\end{array}$ & $\begin{array}{r}0,13375 \\
36 \\
\end{array}$ & $\begin{array}{r}0,10428 \\
75 \\
\end{array}$ & & $\begin{array}{r}0,63819 \\
04 \\
\end{array}$ \\
\hline $\begin{array}{c}\text { NSL } \\
\text { Egr-1 }\end{array}$ & $\begin{array}{r}10112 \\
8 \\
\end{array}$ & $\begin{array}{r}0,26446 \\
13 \\
\end{array}$ & $\begin{array}{r}0,11208 \\
44 \\
\end{array}$ & $\begin{array}{r}0,27232 \\
41\end{array}$ & \begin{tabular}{|r|}
0,17630 \\
04
\end{tabular} & $\begin{array}{r}0,02142 \\
787 \\
\end{array}$ & \begin{tabular}{|r|}
0,7188 \\
326 \\
\end{tabular} & $\begin{array}{r}0,02190 \\
609 \\
\end{array}$ & $\begin{array}{r}0,09842 \\
902 \\
\end{array}$ & $\begin{array}{r}0,12179 \\
89 \\
\end{array}$ & $\begin{array}{r}0,02576 \\
173 \\
\end{array}$ & $\begin{array}{r}0,30369 \\
55\end{array}$ & $\begin{array}{r}0,6381 \\
904 \\
\end{array}$ & \\
\hline
\end{tabular}


Quadro III - Nível de significância dos coeficientes de correlação apresentados no Quadro II.

\begin{tabular}{|c|c|c|c|c|c|c|c|c|c|c|c|c|c|c|}
\hline & $\begin{array}{l}\text { ABL } \\
\text { Fos }\end{array}$ & $\begin{array}{l}\text { ACe } \\
\text { Fos }\end{array}$ & $\begin{array}{l}\text { CA1 } \\
\text { Fos }\end{array}$ & $\begin{array}{l}\text { CA3 } \\
\text { Fos }\end{array}$ & $\begin{array}{c}\text { CPFm } \\
\text { Fos }\end{array}$ & $\begin{array}{l}\text { GD } \\
\text { Fos }\end{array}$ & $\begin{array}{l}\text { NSL } \\
\text { Fos }\end{array}$ & $\begin{array}{c}\text { ABL } \\
\text { Egr-1 }\end{array}$ & $\begin{array}{c}\text { ACe } \\
\text { Egr-1 }\end{array}$ & $\begin{array}{c}\text { CA1 } \\
\text { Egr-1 }\end{array}$ & $\begin{array}{c}\text { CA3 } \\
\text { Egr-1 }\end{array}$ & $\begin{array}{l}\text { CPFm } \\
\text { Egr-1 }\end{array}$ & $\begin{array}{c}\text { GD } \\
\text { Egr-1 }\end{array}$ & $\begin{array}{c}\text { NSL } \\
\text { Egr-1 }\end{array}$ \\
\hline $\begin{array}{l}\text { ABL } \\
\text { Fos }\end{array}$ & & $\begin{array}{r}5,59920 \\
3 e-016 \\
\end{array}$ & $\begin{array}{r}0,71221 \\
36 \\
\end{array}$ & $\begin{array}{r}0,00234 \\
1963 \\
\end{array}$ & $\begin{array}{r}0,52479 \\
23 \\
\end{array}$ & $\begin{array}{r}0,01144 \\
459 \\
\end{array}$ & $\begin{array}{r}0,47768 \\
12 \\
\end{array}$ & $\begin{array}{r}0,01578 \\
166 \\
\end{array}$ & $\begin{array}{r}0,00798 \\
7893 \\
\end{array}$ & $\begin{array}{r}0,96189 \\
76 \\
\end{array}$ & \begin{tabular}{|r|}
0,19567 \\
85 \\
\end{tabular} & $\begin{array}{r}0,98838 \\
43 \\
\end{array}$ & $\begin{array}{r}0,06577 \\
155 \\
\end{array}$ & $\begin{array}{r}0,58182 \\
48 \\
\end{array}$ \\
\hline $\begin{array}{l}\text { ACe } \\
\text { Fos }\end{array}$ & \begin{tabular}{||r|}
5,59920 \\
$3 e-016$ \\
\end{tabular} & & $\begin{array}{r}0,49576 \\
1 \\
\end{array}$ & $\begin{array}{r}0,00106 \\
0279 \\
\end{array}$ & $\begin{array}{r}0,18089 \\
85 \\
\end{array}$ & \begin{tabular}{|r|}
0,01639 \\
69 \\
\end{tabular} & $\begin{array}{r}0,23001 \\
89 \\
\end{array}$ & $\begin{array}{r}0,04609 \\
376 \\
\end{array}$ & $\begin{array}{r}0,03873 \\
856 \\
\end{array}$ & $\begin{array}{r}0,94208 \\
61 \\
\end{array}$ & \begin{tabular}{|r|}
0,35018 \\
01 \\
\end{tabular} & $\begin{array}{r}0,92822 \\
19 \\
\end{array}$ & $\begin{array}{r}0,03739 \\
984 \\
\end{array}$ & $\begin{array}{r}0,15052 \\
17 \\
\end{array}$ \\
\hline $\begin{array}{l}\text { CA1 } \\
\text { Fos }\end{array}$ & $\begin{array}{r}0,71221 \\
36 \\
\end{array}$ & \begin{tabular}{|r|}
0,49576 \\
1 \\
\end{tabular} & & \begin{tabular}{|r|}
0,86283 \\
1 \\
\end{tabular} & \begin{tabular}{|r|}
2,64746 \\
$8 \mathrm{e}-006$ \\
\end{tabular} & \begin{tabular}{|r|}
0,62260 \\
46 \\
\end{tabular} & $\begin{array}{r}0,20898 \\
61 \\
\end{array}$ & $\begin{array}{r}0,03315 \\
682 \\
\end{array}$ & $\begin{array}{r}0,00313 \\
1319 \\
\end{array}$ & $\begin{array}{r}0,26921 \\
38 \\
\end{array}$ & $\begin{array}{r}0,36847 \\
09 \\
\end{array}$ & $\begin{array}{r}0,03501 \\
982 \\
\end{array}$ & $\begin{array}{r}0,23945 \\
8 \\
\end{array}$ & $\begin{array}{r}0,54136 \\
61 \\
\end{array}$ \\
\hline $\begin{array}{l}\text { CA3 } \\
\text { Fos }\end{array}$ & \begin{tabular}{|r|}
0,00234 \\
1963 \\
\end{tabular} & $\begin{array}{r}0,00106 \\
0279 \\
\end{array}$ & $\begin{array}{r}0,86283 \\
1 \\
\end{array}$ & & $\begin{array}{r}0,82313 \\
14 \\
\end{array}$ & \begin{tabular}{|r|}
0,01691 \\
19 \\
\end{tabular} & $\begin{array}{r}0,02999 \\
817 \\
\end{array}$ & $\begin{array}{r}0,15249 \\
22 \\
\end{array}$ & \begin{tabular}{|r|}
0,08122 \\
889 \\
\end{tabular} & $\begin{array}{r}0,27535 \\
24 \\
\end{array}$ & $\begin{array}{r}0,41283 \\
93 \\
\end{array}$ & $\begin{array}{r}0,56055 \\
38 \\
\end{array}$ & $\begin{array}{r}0,00246 \\
2933 \\
\end{array}$ & $\begin{array}{r}0,13158 \\
75 \\
\end{array}$ \\
\hline $\begin{array}{c}\text { CPFm } \\
\text { Fos }\end{array}$ & $\begin{array}{r}0,52479 \\
23 \\
\end{array}$ & $\begin{array}{r}0,18089 \\
85 \\
\end{array}$ & $\begin{array}{r}2,64746 \\
8 e-006 \\
\end{array}$ & $\begin{array}{r}0,82313 \\
14 \\
\end{array}$ & & 0,35439 & $\begin{array}{r}0,05039 \\
913 \\
\end{array}$ & \begin{tabular}{|r|}
0,07473 \\
009 \\
\end{tabular} & $\begin{array}{r}0,02531 \\
525 \\
\end{array}$ & $\begin{array}{r}0,88807 \\
36 \\
\end{array}$ & $\begin{array}{r}0,16489 \\
78 \\
\end{array}$ & $\begin{array}{r}3,42779 \\
8 \mathrm{e}-004 \\
\end{array}$ & $\begin{array}{r}0,39236 \\
33 \\
\end{array}$ & $\begin{array}{r}0,33443 \\
67 \\
\end{array}$ \\
\hline $\begin{array}{l}\text { GD } \\
\text { Fos }\end{array}$ & \begin{tabular}{|r|}
0,01144 \\
459 \\
\end{tabular} & \begin{tabular}{|r}
0,01639 \\
69 \\
\end{tabular} & $\begin{array}{r}0,62260 \\
46 \\
\end{array}$ & \begin{tabular}{|r|}
0,01691 \\
19 \\
\end{tabular} & 0,35439 & & $\begin{array}{r}0,53464 \\
14 \\
\end{array}$ & \begin{tabular}{|r}
0,02614 \\
692 \\
\end{tabular} & \begin{tabular}{|r|}
0,03891 \\
921 \\
\end{tabular} & $\begin{array}{r}0,61329 \\
29 \\
\end{array}$ & $\begin{array}{r}0,11599 \\
28 \\
\end{array}$ & $\begin{array}{r}0,15856 \\
5 \\
\end{array}$ & $\begin{array}{r}0,17695 \\
47 \\
\end{array}$ & \begin{tabular}{|r|}
0,90733 \\
16 \\
\end{tabular} \\
\hline $\begin{array}{l}\text { NSL } \\
\text { Fos }\end{array}$ & \begin{tabular}{|r|}
0,47768 \\
12 \\
\end{tabular} & $\begin{array}{r}0,23001 \\
89 \\
\end{array}$ & $\begin{array}{r}0,20898 \\
61 \\
\end{array}$ & $\begin{array}{r}0,02999 \\
817 \\
\end{array}$ & $\begin{array}{r}0,05039 \\
913 \\
\end{array}$ & \begin{tabular}{|r|}
0,53464 \\
14 \\
\end{tabular} & & $\begin{array}{r}0,60233 \\
04 \\
\end{array}$ & $\begin{array}{r}0,58621 \\
7 \\
\end{array}$ & $\begin{array}{r}0,39412 \\
95 \\
\end{array}$ & $\begin{array}{r}0,54807 \\
6 \\
\end{array}$ & \begin{tabular}{|r|}
0,08473 \\
277 \\
\end{tabular} & $\begin{array}{r}1,85419 \\
6 \mathrm{e}-005 \\
\end{array}$ & $\begin{array}{r}3,58250 \\
5 e-006 \\
\end{array}$ \\
\hline $\begin{array}{c}\mathrm{ABL} \\
\mathrm{Egr-1}\end{array}$ & \begin{tabular}{|r|}
0,01578 \\
166 \\
\end{tabular} & $\begin{array}{r}0,04609 \\
376 \\
\end{array}$ & $\begin{array}{r}0,03315 \\
682 \\
\end{array}$ & $\begin{array}{r}0,15249 \\
22 \\
\end{array}$ & $\begin{array}{r}0,07473 \\
009 \\
\end{array}$ & \begin{tabular}{|r|}
0,02614 \\
692 \\
\end{tabular} & $\begin{array}{r}0,60233 \\
04 \\
\end{array}$ & & $\begin{array}{r}1,89600 \\
0 e-012 \\
\end{array}$ & $\begin{array}{r}0,97727 \\
34 \\
\end{array}$ & $\begin{array}{r}1,69168 \\
7 e-004 \\
\end{array}$ & $\begin{array}{r}0,64632 \\
74 \\
\end{array}$ & $\begin{array}{r}0,07310 \\
526 \\
\end{array}$ & $\begin{array}{r}0,90527 \\
27 \\
\end{array}$ \\
\hline $\begin{array}{c}\mathrm{ACe} \\
\mathrm{Egr}-1\end{array}$ & \begin{tabular}{|r|}
0,00798 \\
7893 \\
\end{tabular} & $\begin{array}{r}0,03873 \\
856 \\
\end{array}$ & $\begin{array}{r}0,00313 \\
1319 \\
\end{array}$ & $\begin{array}{r}0,08122 \\
889 \\
\end{array}$ & $\begin{array}{r}0,02531 \\
525 \\
\end{array}$ & $\begin{array}{r}0,03891 \\
921 \\
\end{array}$ & $\begin{array}{r}0,58621 \\
7 \\
\end{array}$ & \begin{tabular}{|r|}
1,89600 \\
$0 \mathrm{e}-012$ \\
\end{tabular} & & $\begin{array}{r}0,81423 \\
57 \\
\end{array}$ & $\begin{array}{r}0,00081 \\
4728 \\
\end{array}$ & \begin{tabular}{|r|}
0,77941 \\
95 \\
\end{tabular} & $\begin{array}{r}0,04233 \\
868 \\
\end{array}$ & \begin{tabular}{|r|}
0,59199 \\
29 \\
\end{tabular} \\
\hline $\begin{array}{c}\text { CA1 } \\
\text { Egr-1 }\end{array}$ & \begin{tabular}{|r|}
0,96189 \\
76 \\
\end{tabular} & $\begin{array}{r}0,94208 \\
61 \\
\end{array}$ & $\begin{array}{r}0,26921 \\
38 \\
\end{array}$ & $\begin{array}{r}0,27535 \\
24 \\
\end{array}$ & $\begin{array}{r}0,88807 \\
36 \\
\end{array}$ & $\begin{array}{r}0,61329 \\
29 \\
\end{array}$ & $\begin{array}{r}0,39412 \\
95 \\
\end{array}$ & $\begin{array}{r}0,97727 \\
34 \\
\end{array}$ & $\begin{array}{r}0,81423 \\
57 \\
\end{array}$ & & $\begin{array}{r}0,04051 \\
684 \\
\end{array}$ & $\begin{array}{r}0,62295 \\
13 \\
\end{array}$ & $\begin{array}{r}0,76542 \\
61 \\
\end{array}$ & $\begin{array}{r}0,50664 \\
85 \\
\end{array}$ \\
\hline $\begin{array}{c}\text { CA3 } \\
\text { Egr-1 }\end{array}$ & $\begin{array}{r}0,19567 \\
85 \\
\end{array}$ & \begin{tabular}{|r|}
0,35018 \\
01 \\
\end{tabular} & $\begin{array}{r}0,36847 \\
09 \\
\end{array}$ & $\begin{array}{r}0,41283 \\
93 \\
\end{array}$ & $\begin{array}{r}0,16489 \\
78 \\
\end{array}$ & $\begin{array}{r}0,11599 \\
28 \\
\end{array}$ & $\begin{array}{r}0,54807 \\
6 \\
\end{array}$ & $\begin{array}{r}1,69168 \\
7 e-004 \\
\end{array}$ & \begin{tabular}{|r|}
0,00081 \\
4728 \\
\end{tabular} & $\begin{array}{r}0,04051 \\
684 \\
\end{array}$ & & $\begin{array}{r}0,51896 \\
05 \\
\end{array}$ & $\begin{array}{r}0,46550 \\
6 \\
\end{array}$ & $\begin{array}{r}0,88869 \\
53 \\
\end{array}$ \\
\hline $\begin{array}{l}\text { CPFm } \\
\text { Egr-1 }\end{array}$ & $\begin{array}{r}0,98838 \\
43 \\
\end{array}$ & \begin{tabular}{|r|}
0,92822 \\
19 \\
\end{tabular} & $\begin{array}{r}0,03501 \\
982 \\
\end{array}$ & $\begin{array}{r}0,56055 \\
38 \\
\end{array}$ & $\begin{array}{r}3,42779 \\
8 e-004 \\
\end{array}$ & $\begin{array}{r}0,15856 \\
5 \\
\end{array}$ & $\begin{array}{r}0,08473 \\
277 \\
\end{array}$ & $\begin{array}{r}0,64632 \\
74 \\
\end{array}$ & $\begin{array}{r}0,77941 \\
95 \\
\end{array}$ & $\begin{array}{r}0,62295 \\
13 \\
\end{array}$ & $\begin{array}{r}0,51896 \\
05 \\
\end{array}$ & & $\begin{array}{r}0,57002 \\
1 \\
\end{array}$ & $\begin{array}{r}0,09106 \\
895 \\
\end{array}$ \\
\hline $\begin{array}{c}\text { GD } \\
\text { Egr-1 }\end{array}$ & \begin{tabular}{|r|}
0,06577 \\
155 \\
\end{tabular} & \begin{tabular}{|r|}
0,03739 \\
984 \\
\end{tabular} & $\begin{array}{r}0,23945 \\
8 \\
\end{array}$ & $\begin{array}{r}0,00246 \\
2933 \\
\end{array}$ & $\begin{array}{r}0,39236 \\
33 \\
\end{array}$ & $\begin{array}{r}0,17695 \\
47 \\
\end{array}$ & $\begin{array}{r}1,85419 \\
6 \mathrm{e}-005 \\
\end{array}$ & $\begin{array}{r}0,07310 \\
526 \\
\end{array}$ & \begin{tabular}{|r|}
0,04233 \\
868 \\
\end{tabular} & $\begin{array}{r}0,76542 \\
61 \\
\end{array}$ & $\begin{array}{r}0,46550 \\
6 \\
\end{array}$ & $\begin{array}{r}0,57002 \\
1 \\
\end{array}$ & & $\begin{array}{r}8,50132 \\
7 e-005 \\
\end{array}$ \\
\hline $\begin{array}{c}\text { NSL } \\
\text { Egr-1 }\end{array}$ & \begin{tabular}{|r|}
0,58182 \\
48 \\
\end{tabular} & $\begin{array}{r}0,15052 \\
17 \\
\end{array}$ & $\begin{array}{r}0,54136 \\
61 \\
\end{array}$ & $\begin{array}{r}0,13158 \\
75 \\
\end{array}$ & $\begin{array}{r}0,33443 \\
67 \\
\end{array}$ & $\begin{array}{r}0,90733 \\
16 \\
\end{array}$ & $\begin{array}{r}3,58250 \\
5 e-006 \\
\end{array}$ & $\begin{array}{r}0,90527 \\
27 \\
\end{array}$ & \begin{tabular}{|r|}
0,59199 \\
29 \\
\end{tabular} & \begin{tabular}{|r|}
0,50664 \\
85 \\
\end{tabular} & $\begin{array}{r}0,88869 \\
53 \\
\end{array}$ & $\begin{array}{r}0,09106 \\
895 \\
\end{array}$ & $\begin{array}{r}8,50132 \\
7 e-005 \\
\end{array}$ & \\
\hline
\end{tabular}


ANEXO 


\title{
Parecer da Comissão de Ética em Pesquisa com Animais
}

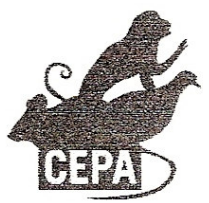

\author{
INSTITUTO DE PSICOLOGIA \\ USP \\ Comissão de Ética em Pesquisa com Animais
}

\section{CERTIFICADO}

Certificamos que o projeto registrado sob o número 010.2008 , para uso de animais em experimentação, intitulado "Expressão dos genes de ativação imediata c-fos e egr-1 em encéfalos de ratos submetidos ao modelo do desamparo aprendido", sob a Coordenação da Profa. Dra. Maria Helena Leite Hunziker, e a participação da aluna Angélica Yochiy foi aprovado pela Comissão de Ética em Pesquisa com. Animal (CEPA) do Instituto de Psicologia, em reunião de 16 de novembro de 2009.

São Paulo, 18 de novembro de 2009

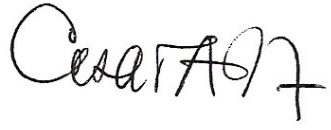

Prof. Dr. César Ades

Coordenador - CEPA

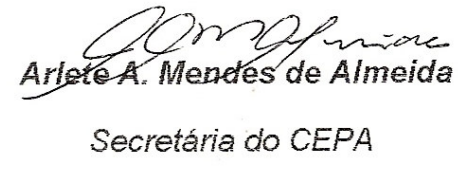

